\author{
UNIVERSIDADE DE SÃO PAULO \\ MUSEU DE ARQUEOLOGIA E ETNOLOGIA \\ PROGRAMA DE PÓS-GRADUAÇÃo EM ARQUEOLOGIA
}

\title{
ASPECTOS DA INTERAÇÃO CULTURAL ENTRE OS GRUPOS CERAMISTAS PRÉ- COLONIAIS DO MÉDIO CURSO DO RIO TOCANTINS
}

ELISANGELA REgINA DE OLIVEIRA

\begin{abstract}
DISSERTAÇÃO APRESENTADA AO PROGRAMA DE PÓS-GRADUAÇÃO EM ARQUEOLOGIA DO MUSEU DE ARQUEOLOGIA E ETNOLOGIA DA UNIVERSIDADE DE SÃO PAULO PARA OBTENÇÃO DO TÍTULO DE MESTRE
\end{abstract}

Orientador: PRof. DR. PAUlo A. D. DE Blasis 


\author{
UNIVERSIDADE DE SÃO PAULO \\ MUSEU DE ARQUEOLOGIA E ETNOLOGIA \\ Programa de Pós-GraduaÇÃo EM ARQUEOLogia
} ASPECTOS DA INTERAÇÃO CULTURAL ENTRE OS GRUPOS CERAMISTAS
PRÉ-COLONIAIS DO MÉDIO CURSO DO RIO TOCANTINS

ELISANGELA REgINA DE OLIVEIRA

SÃo PAULO 
PARA JOÃO, IÊDA E SOLANGE

A ACEITAÇÃO, O AMOR E O RESPEITO QUE TORNARAM TUDO POSSÍVEL. 


\section{AGRADECIMENTOS}

A finalização deste trabalho se deve não apenas às horas solitárias passadas frente à mesa do laboratório e à tela do computador, mas também, e principalmente, àquelas compartilhadas com familiares, amigos de longa data e outros "adquiridos" no decorrer desta empreitada. Àqueles que estiveram presentes, direta ou indiretamente, nos diversos estágios que culminaram com esta dissertação deixo registrado meus sinceros agradecimentos.

Ao Prof. Dr. Paulo Antônio Dantas De Blasis por tantas oportunidades, pela iniciação no trabalho de campo, pela paciência e apoio na acolhida desta "ceramóloga" como orientanda.

À Profa. Dra. Erika Marion Robrahn-González pela orientação na iniciação científica, foram horas ensinando os segredos da análise do material cerâmico e seu potencial interpretativo, e pelo incentivo ao desenvolvimento desta pesquisa.

À Coordenação de Aperfeiçoamento de Pessoal de Nível Superior (CAPES), cuja bolsa de pesquisa permitiu a conclusão deste trabalho.

À INVESTCO S/A que através de seus funcionários do escritório central em Palmas/TO forneceu apoio logístico às etapas de campo.

À Profa. Dra. Silvia Maranca (MAE/USP) pela oportunidade do primeiro estágio em Arqueologia.

Aos Profs. Drs. Adriana Schmidt Dias (UFRGS), Águeda Vilhena-Vialou (MNHN/Paris), Astolfo G. M. Araujo (DPH/São Paulo), Denis Vialou (MNHN/Paris), Dorath Pinto Uchôa, Eduardo Góes Neves e Levy Figuti (MAE/USP) cujos cursos, trabalhos de campo e conversas de corredor tornaram a Arqueologia mais instigante.

À Profa. Silvia Cristina Piedade por apresentar o universo dos artefatos osteodontomalacológicos e dedicar horas em campo ensinando a leitura e o desenho de perfis estratigráficos.

Aos amigos Paulinho e Dária, técnicos do serviço de curadoria do Museu de Arqueologia e Etnologia da Universidade de São Paulo (MAE/USP), por proporcionar alegria ao ambiente dos laboratórios e em tantos campos, assim como pela ajuda incontáveis vezes durante os anos passados nos corredores da curadoria.

Ao pessoal da Seção Acadêmica do MAE/USP (Vanusa Gregório, Regina Leopoldo e Madalena Zeitum) pelo socorro nos momentos de literal agonia, muito obrigado!.

Aos funcionários do Serviço de Biblioteca e Documentação do MAE/USP (Eliana Rotolo, Vera Silva e equipe) pela prontidão no atendimento e ao fotógrafo da instituição, Wagner Souza e Silva, pelas fotos do material arqueológico.

Aos amigos e colegas cujo auxílio, tanto nas etapas de campo quanto nas atividades de 
laboratório, foi imprescindível para a conclusão das metas do trabalho. Para as campanhas de campo formaram-se equipes distintas, cujos membros foram: Camila Azevedo de Moraes (mestranda MAE/USP), Camila Diogo de Souza (mestranda MAE/USP), Carlos Eduardo Rovaron (historiador FFLCH/USP), Eduardo Elston Dias (estagiário MN/UFRJ), Gilberto Bueno (técnico em arqueologia), Job Lobo (geógrafo FFLCH/USP), Ms. Laercio Loiola Brochier (doutorando MAE/USP), Luciane Cabral Monteiro (mestranda MAE/USP), Ms. Marcelo José da Silva Gomes, Maria Emília Vieira de Abreu (mestranda PUC/SP), Rafael Bartolomucci (mestrando MAE/USP) e Ms. Sandra Nami Amenomori (doutoranda MAE/USP). Para a curadoria do material arqueológico foi inestimável a ajuda de Fernando Ozorio de Almeida (mestrando MAE/USP), José Paulo Jacob (técnico MAE/USP) e principalmente de Marília Bueno de Araújo Ariza (estagiária MAE/USP) e da Ms. Luciane Miwa Kamase.

Ao Fábio Fernando da Silva da IME Jr. (Empresa Júnior de Informática, Matemática e Estatística do Instituto de Matemática e Estatística da Universidade de São Paulo) pela realização dos testes estatísticos aqui utilizados.

À Sra. Norma Tavares por acolher esta interiorana em sua casa e proporcionar um ambiente de conforto familiar durante os primeiros anos de faculdade. Sua força e caráter são exemplos dos quais não me esquecerei.

À Beth Navarro Ricomini e José Carlos Ricomini (Piruá, in memorian) pela amizade à minha família que tantas vezes e de diferentes formas contribuiu imensamente para a realização deste trabalho.

À Nami e Lu Kamase pela amizade. Nossos longos bate-papos, quase sempre acompanhados de mesa farta (!!!), me ensinaram muito sobre respeito, companheirismo e Arqueologia.

À Naná e Tica, cujos "ronrons" me acompanham a mais de uma década. Mesmo diante de minhas constantes ausências permanecem companheiras, proporcionando alegria e paz.

Finalmente aos meus pais e minha irmã, a quem dedico este trabalho, sem o apoio incondicional deles não teria conseguido. 


\section{SUMÁRIO}

ÍNDICE .

LISTA DE MAPAS ......

LISTA DE FIGURAS E PRANCHAS

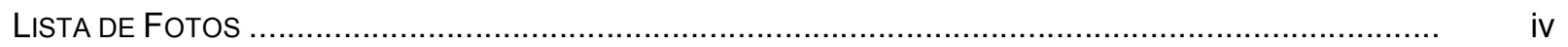

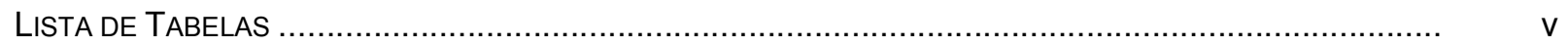

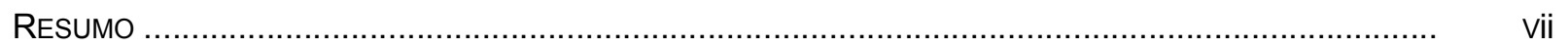

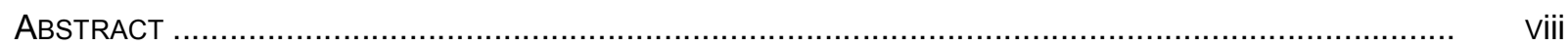

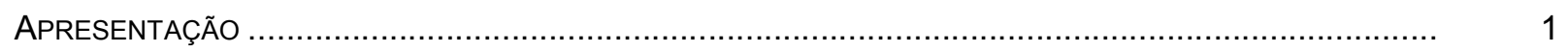

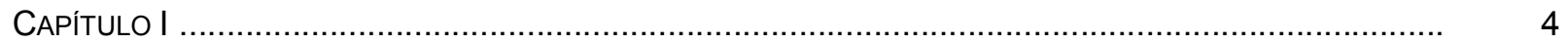

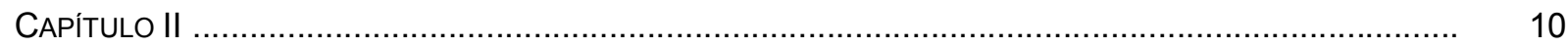

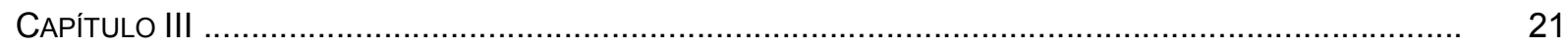

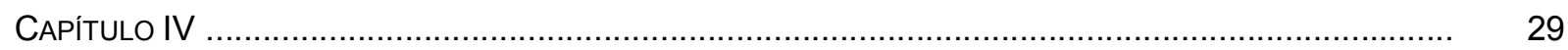

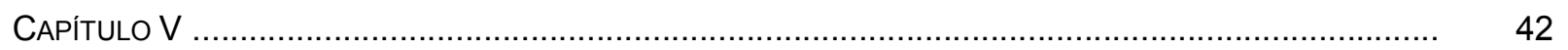

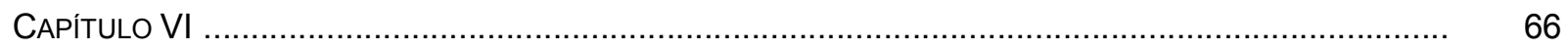

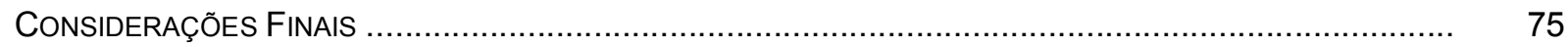

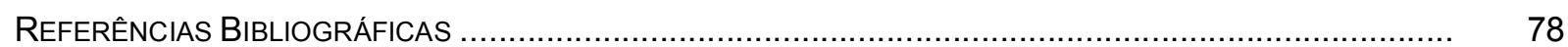

ANEXOS 


\section{ÍNDICE}

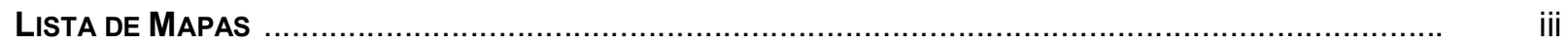

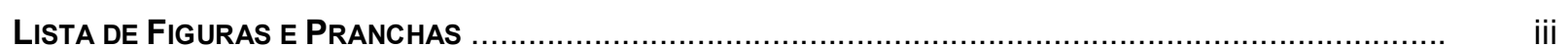

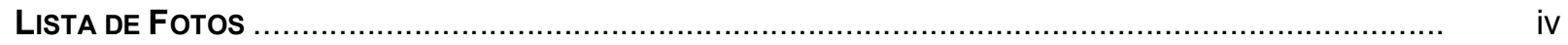

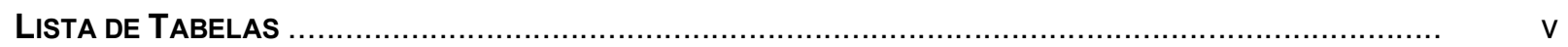

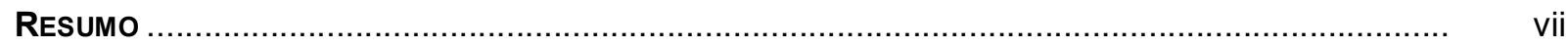

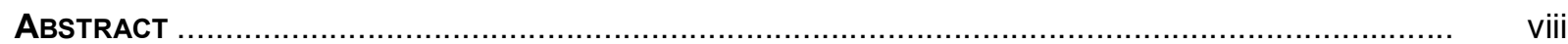

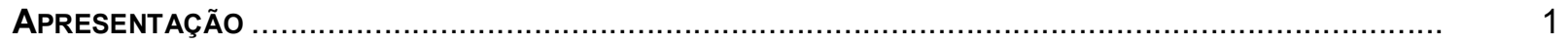

\section{CAPÍTULO I - DIRETRIZES DA PESQUISA}

4

1.1. O Programa de Resgate Arqueológico da UHE Lajeado (PRAL) ...................... 4

1.2. As diretrizes da pesquisa ...................................................................

1.3. A Arqueologia Brasileira e a questão da interação cultural .............................. 8

Capítulo II - CARActerização ambiental da ÁReA estudadA

10

2.1. Localização e descrição física regional ..................................................... 10

2.2. As seções paisagísticas na área do PRAL ................................................... 15

CAPÍtULO III - O CONTEXTO DE OCUPAÇÃo REgIONAL DOS GRUPOS CERAMISTAS

21

3.1. A arqueologia das aldeias circulares ............................................................. 23

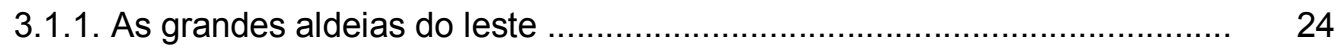

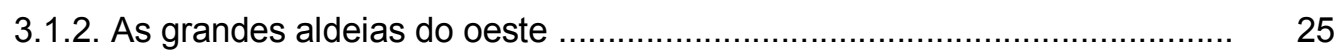

3.1.3. As aldeias do centro norte ............................................................... 25

3.2. Os grupos ceramistas no médio curso do rio Tocantins ................................ 26

3.2.1. A ocupação ceramista na área do PRAL ............................................... 26

CAPÍTULO IV - OS SítIOS ARQUEOLÓGICOS

29

4.1. O trabalho de campo …….............................................................. 29

4.2. Sítio Estiva 2 ................................................................................... 33

4.3. Sítio Estiva 3 …................................................................................. 37

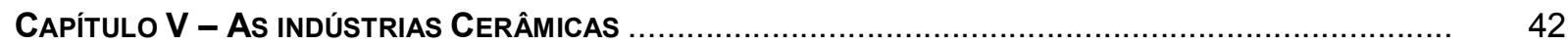

5.1. Objetivos e orientação metodológica da análise ........................................... 42 
5.2. A análise das indústrias cerâmicas dos sítios Estiva 2 e Estiva 3 ................... 43

5.2.1. Descrição geral da indústria cerâmica de Estiva 2 .................................... 58

5.2.2. Descrição geral da indústria cerâmica de Estiva 3 ..................................... 62

\section{Capítulo VI - Análises estatísticas}

66

6.1. Apresentação e discussão dos dados

CONSIDERAÇões FinAIS .

REFERÊNCIAS BIBLIOGRÁFICAS

ANEXOS 


\section{LISTA DE MAPAS}

Mapa 1: Articulação da área de pesquisa do PRAL no contexto nacional

Mapa 2: Distribuição das seções paisagísticas na área do PRAL

Mapa 3: Localização dos sítios Estiva 2 e Estiva 3

\section{Lista de Figuras e Pranchas}

Figura 1: O estado do Tocantins no contexto nacional

Figura 2: Localização das bacias hidrográficas brasileiras

Figura 3: Croqui do sítio Estiva 2

Figura 4: Croqui do sítio Estiva 3

Figura 5: Croqui dos sítios Estiva 2 e Estiva 3

Figuras 6 e 7: Mapas de densidade do material cerâmico no sítio Estiva 2

Figuras 8 e 9: Mapas de densidade do material cerâmico no sítio Estiva 3

Prancha 1: Formas reconstituídas de vasilhames (Formas 1, 2 e 3)

Prancha 2: Formas reconstituídas de vasilhames (Formas 4 e 5)

Prancha 3: Formas reconstituídas de vasilhames (Formas 6 e 7)

Prancha 4: Formas reconstituídas de vasilhames (Formas 8 e 9)

Prancha 5: Material cerâmico identificado no sítio Estiva 2 (fotos Wagner S. Silva) ....

Prancha 6: Material cerâmico identificado no sítio Estiva 3 (fotos Wagner S. Silva). 


\section{LISTA DE FOTOS}

Foto 1: Serra do Lajeado (Paulo De Blasis)

Foto 2: Serra dos Pilões (Sandra Nami Amenomori)

Foto 3: Afloramentos graníticos em trecho de corredeiras (Paulo De Blasis)

Foto 4: Gravura rupestre identificada em lajedo às margens do rio Tocantins (Paulo De Blasis)

Foto 5: Aspecto geral do relevo colinar na margem esquerda do rio Tocantins (Paulo De Blasis)

Foto 6: Detalhe do perfil de uma paleoduna (Paulo De Blasis)

Foto 7: Planície aluvial do Tocantins na região do ribeirão Jaú. Ao fundo

e a direita observa-se a serra do Lajeado (Elisangela R. Oliveira)

Foto 8: Aspecto geral do relevo na região onde se localizam os sítios Estiva 2

e Estiva 3. Ao fundo vê-se o rio Tocantins (Rafael Bartolomucci)

Foto 9: Aspecto geral das grandes planícies que tomam conta do cenário na terceira seção paisagística (Elisangela R. Oliveira)

Foto 10: Planície e morrotes isolados na região do município de Brejinho de Nazaré, terceira seção paisagística (Sandra Nami Amenomori)

Foto 11: Árvores derrubadas no terreno do sítio Estiva 2 (Rafael Bartolomucci)

Foto 12: Implantação dos sítios Estiva 2 e Estiva 3 (Rafael Bartolomucci)

Foto 13: Detalhe da identificação do material de superfície com o auxílio de bandeirinhas azuis (Elisangela R. Oliveira)

Foto 14: Área de decapagem 1 - sítio Estiva 2 (Elisangela R. Oliveira)

Foto 15: Área de decapagem 2 - sítio Estiva 2 (Elisangela R. Oliveira) 
Foto 16: Aspecto geral do terreno no sítio Estiva 3. No centro da foto vê-se uma leira de troncos (Elisangela R. Oliveira)

Foto 17: Vista geral da área onde se localiza o sítio Estiva 3

(Elisangela Regina de Oliveira)

Fotos 18 e 19: Detalhe dos cariapé $A$ e $B$ na pasta cerâmica em peças do sítio Estiva 3 (Wagner Souza e Silva)

\section{LISTA DE TABELAS}

Tabela 1: Quantidade de material analisado por classe nos sítios Estiva 2 e 3

Tabela 2: Total de reconstituições por forma de vasilhame no Sítio Estiva 2

Tabela 3: Total de reconstituições por forma de vasilhame no Sítio Estiva 3

Tabela 4: Estiva 2 / Espessura da peça $(\mathrm{cm})$

Tabela 5: Estiva 2 / Antiplástico

Tabela 6: Estiva 2 / Espessura do antiplástico $(\mathrm{cm})$

Tabela 7: Estiva 2 / Queima

Tabela 8: Estiva 2 / Tipo de lábio

Tabela 9: Estiva 2 / Formas de vasilhames

Tabela 10: Estiva 2 / Volume dos vasilhames (litros)

Tabela 11: Estiva 2 / Diâmetro da borda $(\mathrm{cm})$

Tabela 12: Estiva 2 / Engobo 
Tabela 14: Estiva 3 / Espessura da peça $(\mathrm{cm})$

Tabela 15: Estiva 3 / Antiplástico

Tabela 16: Estiva 3 / Espessura do antiplástico $(\mathrm{cm})$

63

Tabela 17: Estiva 3 / Queima

64

Tabela 18: Estiva 3 / Formas de vasilhames

64

Tabela 19: Estiva 3 / Volume dos vasilhames (litros)

64

Tabela 20: Estiva 3 / Tipo de lábio

64

Tabela 21: Estiva 3 / Diâmetro da borda $(\mathrm{cm})$

Tabela 22: Estiva 3 / Base

65

Tabela 23: Estiva 3 / Decoração

65

Tabela 24: Resultado da análise de Componente Principal (sítio Estiva 2)

68

Tabela 25: Resultado da análise de componente principal (sítio Estiva 3)

70 


\section{Resumo}

Através da análise da variabilidade da indústria cerâmica nos espaços intra e intersítios em dois assentamentos a céu aberto relacionados a grupos ceramistas pré-coloniais filiados às tradições Aratu e Uru e localizados no médio curso do rio Tocantins, este estudo objetivou fornecer parâmetros para o debate acerca de processos de interação cultural entre estes grupos ceramistas, que segundo alguns autores teriam motivado e configurado a ocupação humana pré-colonial do Brasil Central desde pelo menos o século $X$ da era Cristã.

Por meio dos testes estatísticos de Cluster e Componente Principal tal variabilidade é avaliada no intuito de compreender a organização do uso do espaço intra-sítio, bem como o grau de interação presente entre os assentamentos estudados.

Palavras-chave: Brasil Central, grupos ceramistas, interação cultural, tradição Aratu, tradição Uru. 


\section{ABSTRACT}

Through the analysis of the variability of the ceramic industry in the intrasite and intersite spaces in two open air pre-colonial settlements related the ceramist groups associated to the traditions Aratu and Uru and located in the middle course of the Tocantins River, this study objectified to supply parameters the debate concerning processes of cultural interaction between these ceramist groups, that according to some authors would have motivated and configured the pre-colonial occupation human of Central Brazil since at least century $X$.

By means of the statistical tests of Cluster and Principal Component such variability is evaluated in intention to understand the organization of the use of the intrasite space, as well as the degree of present interaction between the studied settlements.

Key-words: Central Brazil, pottery-making groups, cultural interaction, Aratu tradition, Uru tradition. 


\section{APRESENTAÇÃo}

H. âmbito do Programa de Resgate Arqueológico da UHE Luís Eduardo Magalhães - Lajeado / TO a ser apresentada a público. Objetivou-se aqui a investigação de dados que, juntamente aos demais trabalhos realizados através deste Programa de Resgate (Berra 2003, Bueno 2005, Moi 2003 e Morales 2005), possibilitem inferir a médio prazo um primeiro quadro interpretativo acerca do(s) processo(s) da ocupação humana pré-colonial na porção de transição entre o médio e o alto curso da bacia do rio Tocantins.

Desta forma, as informações aqui apresentadas possuem caráter essencialmente exploratório na medida em que a ausência de estudos sistemáticos, ao menos publicados em veículos de divulgação científica, ainda prevalece em grandes extensões de áreas vizinhas ao médio Tocantins e nele próprio. Exceção a este quadro são os trabalhos realizados por Pontim (2004) e Souza (2003) na área do reservatório da UHE Serra da Mesa, localizada no alto curso do rio Tocantins. Assim, de maneira geral foram aqui utilizados como parâmetro de comparação e debate trabalhos realizados entre o final da década de 1970 e meados dos anos 90 em porções dos estados de Mato Grosso e Goiás (Robrahn-González 1996a; Schmitz 1976/77, 1980, 1996; Schmitz \& Barbosa 1985; Schmitz et al. 1981/82, 1982, 1986; Wüst 1983, 1990).

Dentre estes se destaca a pesquisa realizada na década de 1990 pela pesquisadora Erika Marion Robrahn-González, a partir da qual propôs um sólido e abrangente modelo para a interpretação das origens e desenvolvimento dos grupos ceramistas na região do Brasil Central (Robrahn-González 1996a, 1996b). Baseando-se na reinterpretação e no cruzamento estatístico de dados disponibilizados por diversos pesquisadores em diferentes momentos e contextos, a autora sugere que a ocupação ceramista no Brasil Central se processou através de deslocamentos de pessoas, objetos e/ou informações oriundos das regiões circundantes ao Planalto Central, caracterizando um movimento de confluência em cujo cerne estes grupos teriam se desenvolvido por meio de processos de continuidade e 
mudanças, assinalados principalmente por interações culturais entre os diferentes insumos sociais.

Neste modelo a autora aponta evidências de diversos níveis de contato e interação entre os grupos ceramistas no Brasil Central, identificados com as tradições Una, Aratu, Uru e Tupiguarani. Todavia, o contato mantido entre os portadores das tradições Aratu e Uru foi o que desenvolveu os mais profundos processos internos de mudança cultural, culminando com a emergência de um novo grupo cultural, por ela denominado de "agricultores do centro-norte". Segundo suas análises, a interação entre estes grupos teria se intensificado a partir do século $X$ através de estímulos diversos, muito "provavelmente relacionados a dinâmicas locais e específicas de mudança cultural" (op. cit.: 211).

Este novo grupo teria surgido entre os médio/alto cursos dos rios Araguaia/Tocantins com uma indústria cerâmica apresentando predomínio dos elementos tecnológicos e estilísticos da cerâmica Uru, assentamentos menores e implantados em compartimentos paisagísticos mais diversos se comparados às grandes aldeias circulares das áreas core Aratu (a leste do Araguaia) e Uru (a oeste do Araguaia). A grosso modo, os dados sugerem o predomínio do componente Uru no processo de fusão, talvez devido à presença de um contingente populacional maior que já vinha ocupando áreas outrora de domínio dos grupos Aratu, num processo culminado por uma possível crescente complexificação sócio-política entre os grupos ceramistas Uru (Wüst 1990 apud Robrahn-González 1996a).

Corroborando a hipótese da interação cultural resultando na fusão destes grupos, Rogge (2004) afirma que, em contextos sem indícios de sobreposição de ocupações ou nos quais sabidamente os processos deposicionais e pós-deposicionais tenham interferido minimamente no registro arqueológico, a presença de elementos estilísticos, tanto quanto objetos, de um grupo em contextos de outros são indicativos de processos de interação caracterizados pela integração e cooperação entre populações, não apenas através da troca de objetos e técnicas como também pelo fluxo de indivíduos (Rogge 2004: 20).

É certo, contudo, que interações e contatos culturais não ocorreram apenas entre os grupos ceramistas, mas também destes com grupos caçadores-coletores e destes entre si. Como ressalta Robrahn-González (1996a, 1996b), de fato os grupos caçadores-coletores contribuíram em maior ou menor escala tanto na origem quanto no desenvolvimento dos grupos ceramistas no Brasil Central.

Todavia, optou-se, na presente pesquisa, pelo estudo da interação entre os grupos ceramistas devido ao fato de que para este contexto a bibliografia disponibiliza dados mais concretos tanto quanto a caracterização da cultura material, como quanto a identificação dos processos de interação presentes entre eles.

Desta maneira, através do estudo da variabilidade da indústria cerâmica nos espaços intra e inter-sítios em dois assentamentos pré-coloniais filiados às tradições Aratu e Uru, 
pretende-se iniciar nesta dissertação uma discussão acerca de aspectos de interação cultural que estes grupos ceramistas mantiveram no médio rio Tocantins. Cabe ressaltar, porém, que não foi identificada na estratigrafia ou na estrutura dos assentamentos simultaneidade na ocupação dos sítios, fato que as datações vieram a confirmar, mas constatou-se a sobreposição do sítio Aratu (Estiva 2) sobre o sítio Uru (Estiva 3).

Este tipo de interação, na qual ocorre sobreposição de ocupações e através da qual é possível observar a "reciclagem" por parte de uma população dos artefatos abandonados por outra, é de difícil constatação, principalmente em contextos no qual a espessura do refugo raramente ultrapassa $30 \mathrm{~cm}$ de profundidade e onde intervenções pós-deposicionais antrópicas tendem a mascarar sutis alterações presentes no registro arqueológico.

Pretende-se, pois, chamar a atenção que para uma melhor compreensão da natureza da interação cultural, análises detalhadas em nível de sítio devem ser realizadas mais frequentemente, bem como o estudo do espaço inter-sítio. Algo já salientado nos trabalhos de Wüst (2000, Wüst \& Barreto 1999, Wüst \& Carvalho 1996) e da própria Robrahn-González (1996a) e cuja aplicação tem sido gradativa por parte de diversos pesquisadores que atuam na região do Brasil Central (entre outros Faccio et al. 1998; Mello 1995; Morales 2005; Pontim 2004; Sousa 2003).

De fato, a presença de processos de interação cultural entre os grupos ceramistas são um dos aspectos mais ressaltados pelos pesquisadores que trabalham no Planalto Central (entre os já mencionados inclui-se Schmitz 1980, 1996; Schmitz \& Barbosa 1985; Schmitz et al. 1981/82, 1982, 1986). Assim sendo, no intuito de explorar esta temática a presente dissertação encontra-se estruturada da seguinte forma: No primeiro capítulo são apresentadas as diretrizes teórico-metodológicas do trabalho. A caracterização ambiental da área estudada, sua localização e descrição física regional ocupam o segundo capítulo. No terceiro capítulo têm-se uma síntese dos contextos referentes à ocupação de grupos ceramistas relacionados às tradições Aratu e Uru na macro-região do Brasil Central, cujos dados constituem referência básica para as discussões aqui levantadas. No quarto capítulo estão descritas as atividades realizadas em campo nos sítios analisados, bem como as características de implantação, estado de conservação e articulação destes na paisagem. O quinto capítulo comporta os objetivos, os métodos e a descrição pormenorizada das análises realizadas no material cerâmico presente em ambos os sítios, bem como são apresentadas as características de cada uma das indústrias pesquisadas através da análise descritiva do material. No sexto capítulo são expostos os resultados das análises estatísticas realizadas, cuja avaliação crítica se dá nas Considerações finais, onde são confrontadas as diretrizes da pesquisa com os resultados das análises realizadas. 


\section{CAPÍtulo I}

DIRETRIZES DA PESQUISA

\subsection{O Programa de Resgate ARQueológico da UHE LAJEAdo (PRAL)}

\section{E ste trabalho encontra-se vinculado ao Programa de Resgate Arqueológico da} UHE Luís Eduardo Magalhães - Lajeado / TO, projeto coordenado pelos Profs. Drs. Paulo De Blasis e Erika Marion Robrahn-González e resultado do contrato de seis anos (1998 a 2003) firmado entre a INVESTCO S/A, empresa responsável pelo empreendimento hidrelétrico, e o Museu de Arqueologia e Etnologia da Universidade de São Paulo (MAE/USP), instituição responsável pelo resgate, curadoria e estudo do patrimônio arqueológico impactado pela referida obra.

A usina foi construída na região central do estado do Tocantins e o reservatório, que começou a ser formado no ano de 2001, ocupa uma área de $793 \mathrm{Km}^{2}$, estendendo-se da cidade de Lajeado, onde se localiza o eixo da barragem, em direção sul até o município de Ipueiras, perfazendo aproximadamente $180 \mathrm{~km}$ de extensão.

O objetivo principal deste Programa foi o resgate dos contextos arqueológicos impactados pela construção da referida usina hidrelétrica. Desta forma, devido à quantidade, diversidade e complexidade dos sítios arqueológicos identificados durante o resgate no eixo da barragem (De Blasis \& Robrahn-González 1998; Robrahn-González \& De Blasis 1997), a pesquisa nesta extensa área englobou diferentes abordagens de investigação durante três grandes etapas de trabalho, na qual foi dividida a pesquisa do Programa de Resgate Arqueológico da UHE Lajeado (PRAL).

Na primeira etapa, desenvolvida no ano de 1998, realizou-se o mencionado resgate no eixo da barragem e adjacências. Na segunda etapa, entre os anos de 1999 e 2001, procedeu-se a investigação intensiva da área diretamente afetada (ADA) pelas águas do reservatório afim de identificar a natureza e a diversidade das evidências nela presentes e a investigação extensiva na área de influência ( $\mathrm{Al}$ ) contínua à $\mathrm{ADA}$, objetivando a obtenção de dados de referência e contextualização para os vestígios identificados na área do lago. 
Durante os anos de 2001 e 2002 foi realizada a terceira etapa, que comportou a investigação de problemas arqueológicos específicos, arquitetados a partir da avaliação do quadro arqueológico de referência obtido na etapa anterior (De Blasis \& Robrahn-González 2003).

Tais problemas de investigação, entre os quais a busca de elementos para o reconhecimento de padrões de ocupação da paisagem a partir de prospecções intensivas em áreas amostrais definidas dentro da ADA e o estudo detalhado de alguns sítios visando entender o papel dos mesmos dentro do sistema de assentamento a que se relacionam, impulsionaram a estruturação de cinco projetos acadêmicos de pesquisa, desenvolvidos por alunos de pós-graduação e orientados pelos coordenadores do Programa de Resgate.

Complementares às propostas e objetivos vinculados aos compromissos contratuais com o empreendedor, os projetos acadêmicos foram concebidos de modo a ampliar o conhecimento sobre os processos de ocupação humana nesta porção da bacia do rio Tocantins e seu papel dentro do contexto arqueológico regional mais amplo a que se relacionam (Berra 2003, Bueno 2005, Moi 2003, Morales 2005, Oliveira 2004).

O presente trabalho foi desenvolvido nesta perspectiva, tendo como objetivo explorar processos de interação cultural entre os grupos ceramistas localizados na área investigada pelo PRAL através da compreensão da organização do uso do espaço intra-sítio, bem como as relações no espaço inter-sítio, em dois assentamentos pré-coloniais filiados às tradições Aratu e Uru. Com o intuito de caracterizar aspectos da organização sócio-política destes grupos, bem como das possíveis interações entre eles, procedeu-se a análise espacial da variabilidade da indústria cerâmica presente nos assentamentos estudados, pensando que tal variabilidade pode relacionar-se a processos de obtenção, transformação, distribuição e trocas internas e/ou externas de objetos, assim como à circulação de pessoas.

\subsection{AS DIRETRIZES DA PESQUISA}

Na segunda metade da década de 1990 o trabalho da arqueóloga Erika M. RobrahnGonzález levantou a hipótese de que a região Centro-Oeste brasileira se caracterizou, em período pré-colonial, como uma área de confluência para deslocamentos de pessoas, objetos e/ou informações relacionados a grupos ceramistas oriundos das regiões circundantes ao Planalto Central (Robrahn-González 1996a: 213). Tal processo teria se intensificado nos primeiros séculos da nossa Era durante a maciça ocupação da região pelas sociedades construtoras de grandes aldeias circulares, arqueologicamente denominadas de tradições Aratu e Uru, gerando um contínuo de contatos e interações extra- 
grupais que culminaram em formas distintas de interação, por um lado com a consolidação da autonomia de alguns grupos, e por outro com a gradativa fusão de outros, gerando novas unidades socioculturais. Arqueologicamente tal processo pôde ser vislumbrado através da mescla de elementos tecnológicos, morfológicos e estilísticos na manufatura cerâmica, assim como na forma e implantação dos assentamentos, que geraram sítios "mistos" indicativos que dos contatos extra-grupais, seja de que natureza fosse, teriam resultado a simbiose entre grupos ao menos tecnologicamente distintos.

Neste mesmo estudo Robrahn-González identificou que os assentamentos cuja indústria associada é um misto de elementos das tradições Aratu e Uru localizam-se predominantemente entre os alto/médio cursos dos rios Araguaia e Tocantins e que estes seriam indicadores do surgimento de um novo grupo denominado por ela de "agricultores do centro-norte". De fato, um padrão recorrentemente observado nos sítios ceramistas do médio Tocantins foi a presença de componentes de duas ou mais tradições em um mesmo sítio (De Blasis \& Robrahn-González 2003), que poderia refletir tanto processos internos de mudança quanto fusões de grupos portadores de tecnologias distintas ou mesmo a sobreposição de ocupações.

Considerando as datações obtidas para os sítios identificados na área impactada pela UHE Lajeado, entre os séculos XII e XV (De Blasis \& Robrahn-González 2003), vê-se que estão situados neste período, caracterizado como de intensa mudança na estrutura interna destas sociedades (Robrahn-González 1996a, Wüst 1990). As datações obtidas para os sítios aqui pesquisados os situam exatamente neste conturbado período $(760 \pm 60 \mathrm{BP}$ Beta 184620 para o sítio Estiva 2 e 970 120 - LVD 1239 para Estiva 3).

Os sítios identificados no médio Tocantins parecem indicar, ainda, que à expansão oeste-leste dos grupos portadores da cerâmica Uru (Robrahn-González 1996a, 1996b) teria se sucedido, em período tardio (séculos XIV e XV), uma expansão sentido sul-norte pela bacia do Tocantins, cujo limite de ocorrência seria a confluência Araguaia/Tocantins. $O$ médio Tocantins seria caracterizado, portanto, como a área mais setentrional de ocorrência destes agricultores.

Assim sendo, este aspecto da interação cultural da ocupação ceramista no Brasil Central se revelou uma interessante problemática de pesquisa a ser investigada através da análise espacial intra-sítio (Allison 1999; Arnold 1990; Carr 1984; Hietala 1984; Kroll \& Price 1991; Wüst 2000). De modo que, afim de proporcionar maior alcance interpretativo dos dados obtidos nesta pesquisa, as análises foram estruturadas de modo a fornecer parâmetros de comparação com trabalhos na mesma perspectiva intra-sítio realizados no Brasil Central (Mello 1995; Viana 1996; Wüst 2000; Wüst \& Carvalho 1996). Assim sendo, ainda que com os limites interpretativos na análise de dois estudos de caso, este trabalho pretende inserir-se na problemática regional da ocupação de grupos ceramistas no Brasil 
Central, introduzindo de forma exploratória elementos para a melhor compreensão do(s) processo(s) de ocupação humana nesta macro-região.

Os trabalhos pioneiros em análises espaciais intra-sítio realizados no Brasil Central (Viana 1996; Wüst 2000; Wüst \& Carvalho 1996) têm demonstrado como é possível inferir aspectos relativos à organização social, política e econômica das sociedades pretéritas a partir da identificação da organização do espaço interno das aldeias. A caracterização deste espaço pode ser obtida através do reconhecimento e interpretação da variabilidade das indústrias arqueológicas e de seu padrão de distribuição espacial.

A pesquisa encontra, de fato, alcance e respaldo em problemáticas arqueológicas regionais estabelecidas por trabalhos realizados em áreas circundantes ao médio Tocantins. Nas últimas duas décadas o Brasil Central tem sido alvo de pesquisas sistemáticas relacionadas a grupos ceramistas, notadamente nos estados de Goiás e Mato Grosso, cujo foco encontra-se na gênese e nas relações que estes grupos mantiveram entre si e com aqueles presentes em áreas limítrofes como a bacia Amazônica, a planície chaquenha, a região centro-norte de Minas Gerais e o interior da Bahia (Heckenberger 2000; RobrahnGonzález 1996a, 1996b; Schmitz 1996; Schmitz et al. 1982; Wüst 1983, 1990, 1999; Wüst \& Barreto 1999).

A base de investigação deste projeto é a análise das indústrias cerâmicas associadas aos sítios pesquisados, tais análises abrangeram estudos quantitativos e qualitativos através do tratamento estatístico dos dados levantados. Cabe ressaltar, também, que no atual estágio da pesquisa, uma vez constatada grande homogeneidade entre o material lítico presente nos assentamentos, bem como uma distribuição espacial aparentemente aleatória, estes não foram considerados nas análises aqui desenvolvidas.

$\mathrm{Na}$ interpretação do padrão de distribuição espacial dos vestígios nos sítios estudados fez-se uso de modelos etnográficos de uso do espaço relacionados a sociedades Jê, na medida cuja aplicação no estudo de sítios relacionados a grupos ceramistas do Brasil Central mostrou-se bastante profícua (Robrahn-González 2004). Trabalhos na linha da Etnoarqueologia são fontes preciosas de instrumentos de análise que os arqueólogos dispõem para tentar compreender "as relações existentes entre o comportamento humano e os vestígios materiais que deles resultam" (Silva 2000) ou o "contexto sistêmico" da informação proveniente do registro (contexto) arqueológico segundo Schiffer (1972). 


\subsection{A ARQUEOLOgia BRAsileira E A QUESTÃo dA INTERAÇÃo CULTURAL}

No âmbito da Antropologia um dos temas recorrentemente tratados com relação à interação cultural diz respeito principalmente ao estudo da interação entre sociedades indígenas e européias à época da conquista do Novo Mundo e da formação dos Estados Nacionais. Ao final da década de 1970 Cardoso de Oliveira propôs uma "teoria do contato" que veio a influenciar os estudos antropológicos realizados entre os anos 70 e 80 , até que na década de 1980 emergiram estudos acerca do contato cultural entre populações indígenas, os chamados "contatos tribais" (Ramos 1980 apud Rogge 2000).

Apesar de discutida desde longa data pela Antropologia (Wilmsen 1972), para a Arqueologia Brasileira durante anos a problemática da interação cultural foi ignorada ou teve por parte dos pesquisadores um interesse limitado, circunscrito a notas pontuais. Apesar das evidências de processos de interação serem gradualmente identificadas em diversas pesquisas realizadas por todo país, nenhuma propôs trabalhar em detalhe este aspecto. Como exceção a este quadro é possível mencionar, além do já citado trabalho de RobrahnGonzález (1996a, 1996b) para o Brasil Central (que impulsionou a realização de outros nesta linha no Planalto Central, como os trabalhos de Pontim 2004 e Souza 2003), a pesquisa recentemente concluída entre os grupos ceramistas do Planalto Meridional do Rio Grande do Sul de autoria de J. H. Rogge.

O trabalho de Rogge (2004) procurou sintetizar a abordagem desta temática tanto do ponto de vista arqueológico quanto do antropológico, e discutindo conceitos como fronteira, migração, território e estilo cerâmico o autor realizou uma análise acerca dos "fenômenos de fronteira" detectados entre os portadores das cerâmicas Tupiguarani, Taquara e Vieira no Rio Grande do Sul.

Também recentemente a própria professora Erika M. Robrahn-González retomou o estudo desta temática, não mais entre as populações do Brasil Central, mas entre os grupos relacionados às tradições cerâmicas Itararé e Tupiguarani, cuja natureza dos contatos teria caracterizado o estado de São Paulo como uma "terra de fronteiras" (Robrahn-González 2000, 2003).

A realização de tais trabalhos tem demonstrado, pois, a importância do estudo de processos de interação cultural como um relevante vetor de informação na compreensão das origens, estrutura e desenvolvimento das sociedades indígenas pré-coloniais brasileiras. De fato, como aponta Rogge (2004: 23) a interação entre populações não se constitui em exceção, este fenômeno permeia as sociedades humanas desde os mais remotos tempos, o convívio refletido através da troca de informações, experiências e mesmo a simbiose entre diferentes sistemas socioculturais ocorreu e ocorrem nas mais diferentes culturas. Antropólogos já discutiram criticamente o conceito de "isolamento cultural", e a idéia de que 
possa ter havido alguma sociedade em algum tempo que tenha permanecido completamente isolada é amplamente refutada.

$\mathrm{E}$ de fato, não apenas a constatação de que em menor ou maior escala todas as sociedades já experimentaram contatos culturais, mas também que tal processo pode ser averiguado através da pesquisa arqueológica, ou seja, que fenômenos de contato e interação entre populações podem ser apreendidos em aspectos da cultura material são aqui aceitos como plausíveis.

Durante alguns anos a idéia de aculturação, surgida nos Estados Unidos do século XIX, no qual a interação cultural se caracteriza basicamente como a relação entre uma cultura doadora e outra receptora, dominou a agenda de discussão sobre o tema. Porém, gradativamente a noção de aculturação tem agregado novas abordagens, mais dinâmicas à idéia da interação (Linton 1940; Spicer 1961; Foster 1960).

Atualmente alguns autores tendem a interpretar o contato cultural como um processo que envolve mútuas e múltiplas relações, de forma que os grupos sociais envolvidos estabelecem uma rede mais complexa que a relação doador - receptor. Tal complexidade pode ser averiguada a partir da diversidade de abordagens utilizadas nestes estudos, que de maneira geral formulam a questão do contato cultural em torno de processos de interação que se desenvolvem e se desenrolam entre eles (Rogge 204: 30).

Assim sendo, e uma vez que a noção de aculturação como processo de mão única é definitivamente abandonado, passa-se a utilizar aqui, tal qual sugerido por Rogge, o termo interação por agregar a noção de multiplicidade dos processos que envolvem o contato cultural. 


\section{CAPÍtulo II}

CARACTERIZAÇÃO AMBIENTAL DA ÁREA ESTUDADA

\subsection{LOCALIZAÇÃO E DESCRIÇÃo FÍSICA REGIONAL}

\section{A área pesquisada pelo Programa de Resgate Arqueológico da UHE Luís} Eduardo Magalhães - Lajeado (PRAL) abrangeu o trecho de transição entre o alto e o médio rio Tocantins compreendido entre os municípios de Miracema do Tocantins, ao norte do estado do Tocantins, e Ipueiras, ao sul do estado (mapa 1). Afim de fornecer um quadro sintético do contexto ambiental desta área serão aqui apresentadas as principais características de elementos como padrões de drenagem, formas de vegetação, relevo, geologia e solos a partir de dados coletados em publicações do Instituto Brasileiro de Geografia e Estatística (1988; 2003).

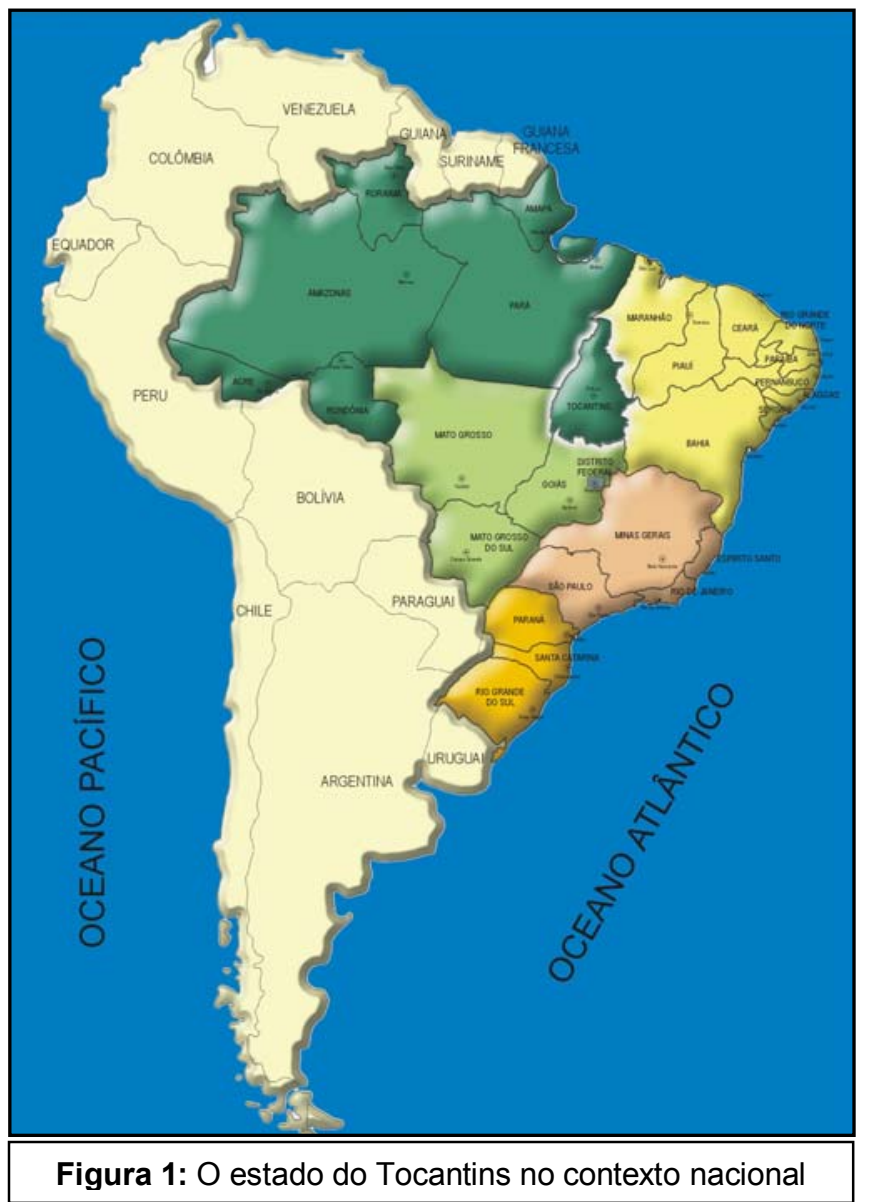

Integrando a região Norte segundo a divisão política brasileira (figura 1), o estado do Tocantins, com topografia simples e estrutura geológica complexa, apresenta uma paisagem refletida em dois andares principais: $\underline{0}$ superior, do cerrado e florestas de galeria, com solos pobres originados de arenitos horizontais; e o inferior das florestas e cerrado, com solos de riqueza variável provenientes de rochas metamórficas fortemente dobradas ou cristalinas muito perturbadas. Apesar de apresentar-se em grande parte bastante descaracterizada pelas sucessivas queimadas para abertura de pastagens e plantações em larga escala, a vegetação florestal e campestre ainda permanece 


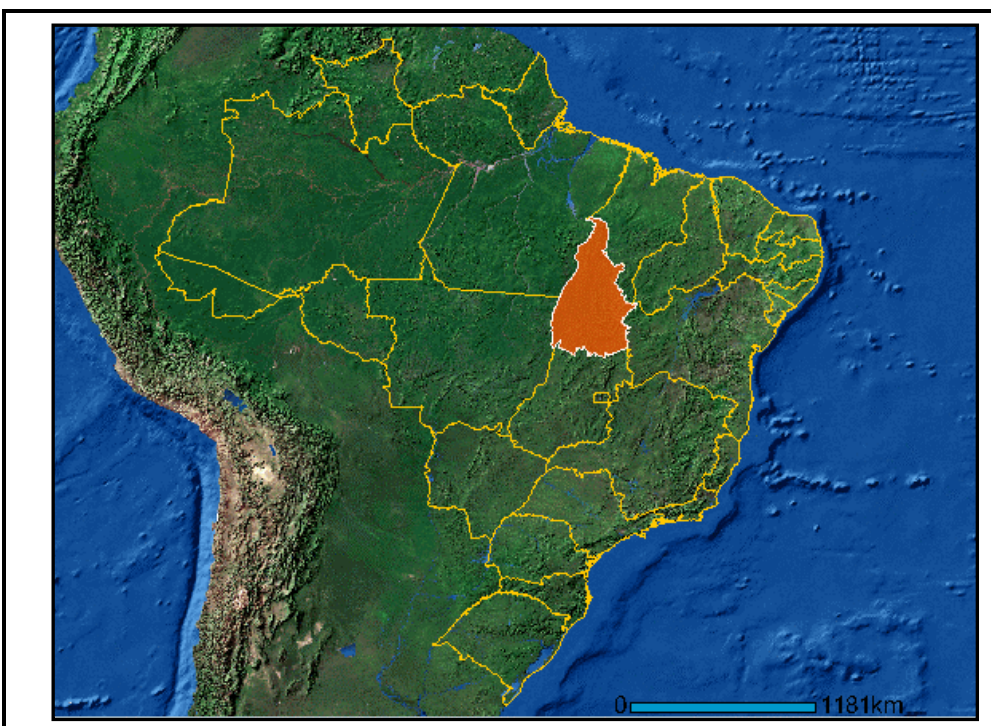

Fonte: IBGE 2002

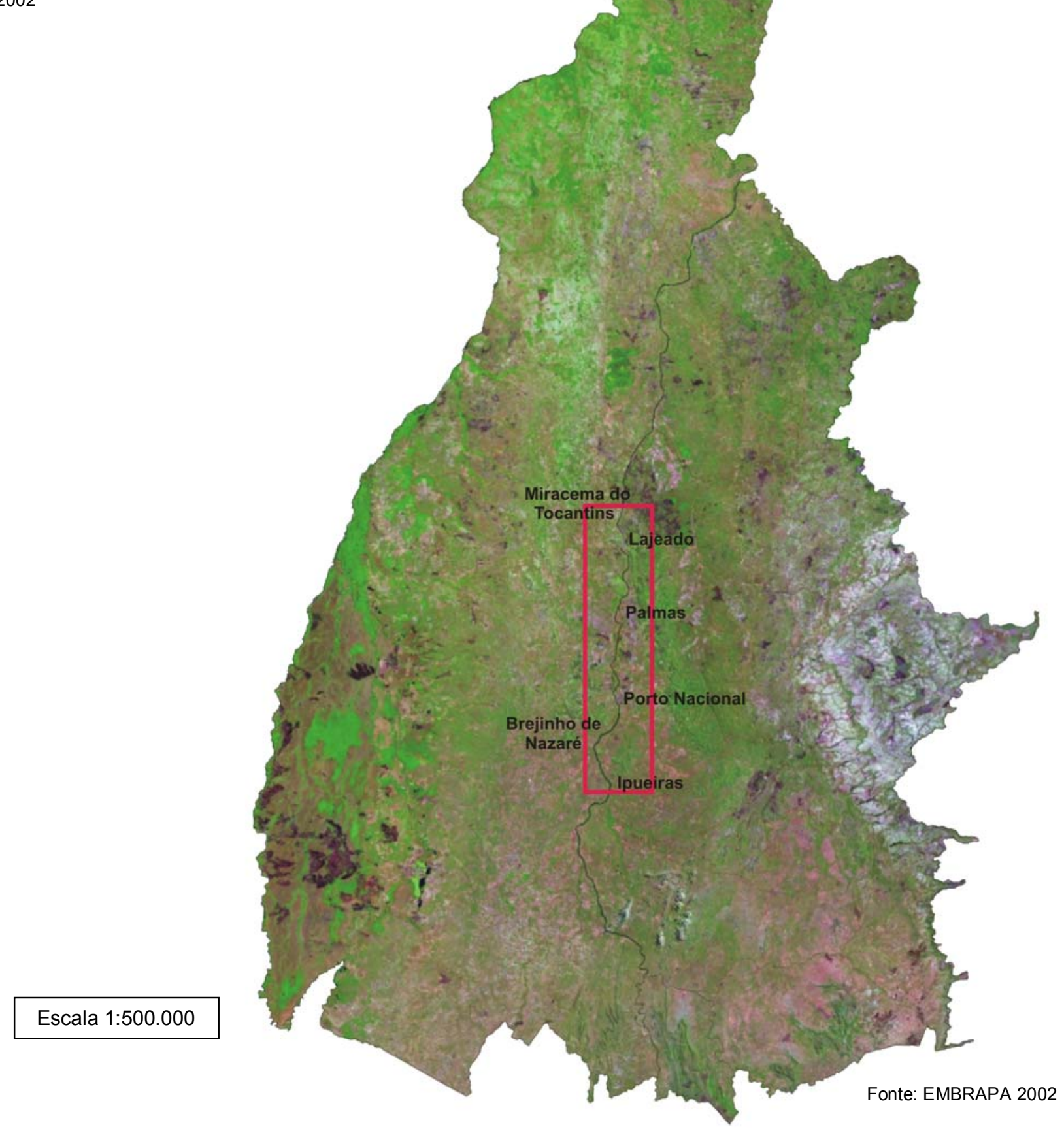

Mapa 1: Localização da área de pesquisa do PRAL no contexto nacional 
com núcleos de agrupamentos florestais primários, onde se observa a presença das formas de vegetação da floresta ombrófila densa e aberta (floresta semicaducifólia e caducifólia), do cerrado e de áreas de tensão ou transição ecológica.

As áreas de tensão ecológica permitem caracterizar o estado como um ecótono ou zona de transição entre três grandes biomas presentes no país, a Amazônia, a Caatinga e o Cerrado, propiciando, pois, uma grande miríade de ambientes. Enquanto no extremo norte-noroeste do estado o cenário apresenta forte influência da Floresta Tropical Amazônica, no centro-sul do território tocantinense, englobando a área de pesquisa, o bioma predominante é o Cerrado, cuja área core localiza-se no Planalto Central Brasileiro.

Este bioma apresenta muitas variedades na sua fisionomia, que segundo Warming \& Ferri (1973) estão ligadas à natureza do terreno, dos declives e da composição dos solos, englobando diversas formações, tais como o cerradão, o cerrado propriamente dito, o campo cerrado, o campo sujo e o campo limpo, formação essencialmente campestre.

Em meio ao bioma Cerrado encontram-se as nascentes das maiores bacias hidrográficas brasileiras: Amazônica, São Francisco, Paraná-Paraguai (ou do Prata) e Tocantins-Araguaia (Ferri 1977). As águas desta última banham integralmente o estado do Tocantins, sendo que as bacias dos seus principais formadores, os rios Araguaia e Tocantins, drenam cerca de $70 \%$ de seu território (figura 2 ).

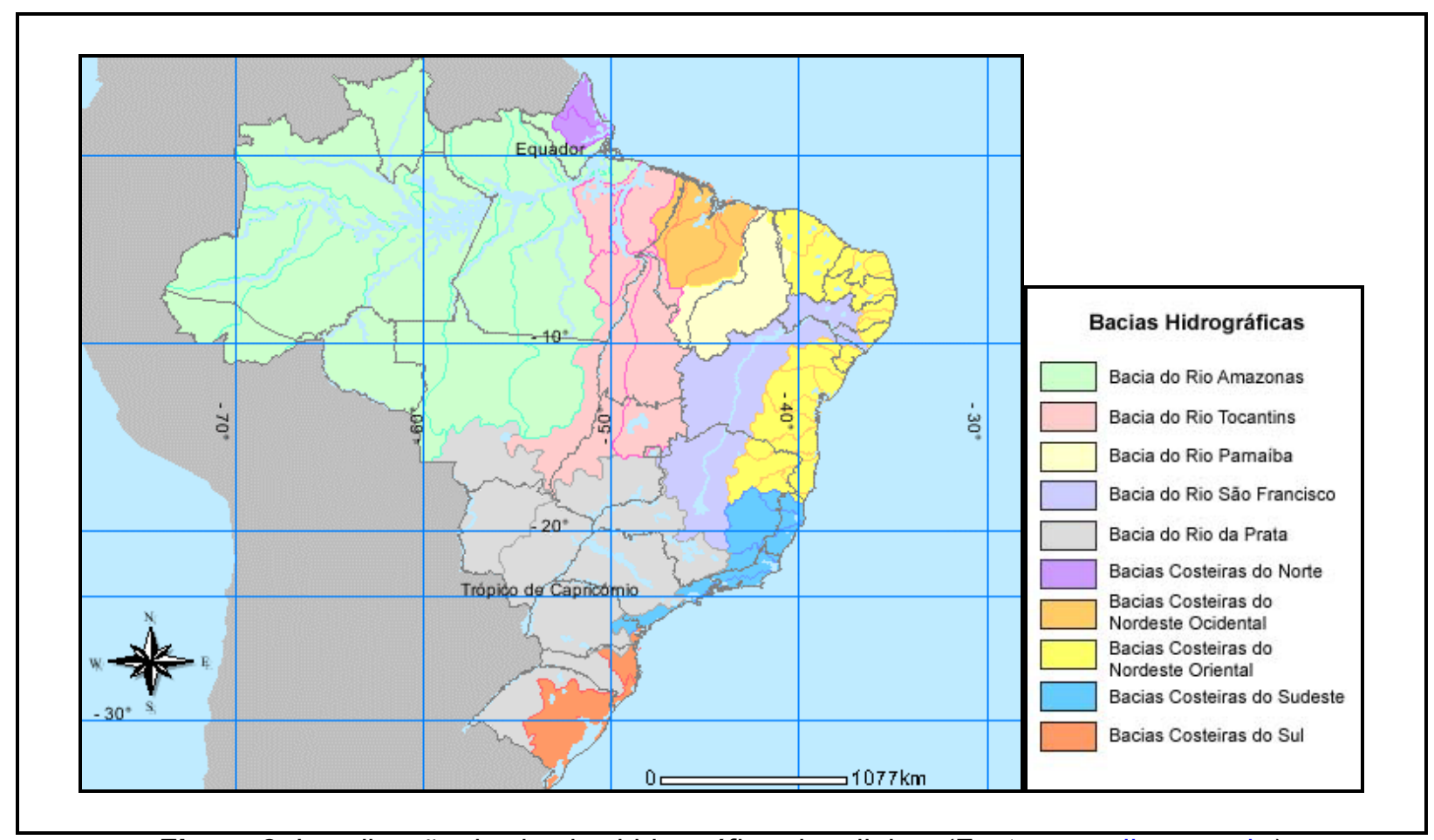

Figura 2: Localização das bacias hidrográficas brasileiras (Fonte: $\underline{w w w . i b g e . g o v . b r)}$

Nas últimas décadas tem-se explorado intensamente o potencial energético da bacia Tocantins-Araguaia (o maior do país em kW juntamente com o da bacia Amazônica) através 
da construção de usinas hidrelétricas notadamente ao longo do curso do rio Tocantins. O impacto de tais obras no meio ambiente é grande e por vezes extrapola os limites da área inundada, a exemplo da implantação da UHE Tucuruí, localizada cerca de $300 \mathrm{~km}$ ao sul de Belém, estado do Pará, cuja interferência no curso do Tocantins tem modificado a configuração da foz deste no decorrer dos anos, chegando mesmo a atingir a foz do rio Amazonas, localizada quilômetros a norte. Em contrapartida, os Estudos de Impacto Ambiental (EIA-RIMA) nas regiões afetadas por tais empreendimentos têm proporcionado a exploração de áreas até então arqueologicamente desconhecidas, de grande importância para o entendimento da ocupação humana pretérita do território brasileiro.

O rio Tocantins, principal formador da bacia Tocantins-Araguaia, percorre uma extensão de 2.400 km, no sentido sul-norte, da nascente, na confluência dos rios Maranhão e das Almas no norte do estado de Goiás, até a foz localizada nas proximidades da cidade de Belém, estado do Pará. Na fronteira entre os estados do Tocantins, Pará e Maranhão o rio recebe seu mais importante afluente, o Araguaia, que corre aproximadamente paralelo a oeste dele até o encontro das águas nesta região de peculiar conformação conhecida como "bico do papagaio".

Na região de Tucuruí o rio atingia até $3 \mathrm{~km}$ de largura e em alguns pontos até $40 \mathrm{~m}$ de profundidade, numa paisagem repleta de quedas d'água hoje submersas pelas águas do reservatório da UHE de mesmo nome. Na foz o Tocantins pode atingir até $15 \mathrm{~km}$ de largura. Comumente seu curso é dividido em 3 trechos, assim distribuídos pela vasta extensão que percorre (IBGE 1988):

a) alto Tocantins: das nascentes até a cachoeira do Lajeado (1.060 km de extensão);

b) médio Tocantins: da cachoeira do Lajeado até a cachoeira Itaboca (980 km);

c) baixo Tocantins: da cachoeira Itaboca até a foz $(360 \mathrm{~km})$.

$\mathrm{Na}$ maior parte de seu curso o rio atravessa o estado de mesmo nome, tendo os médio e alto trechos seccionados por numerosas cachoeiras de reduzido vulto, resultado da natureza geológica e tectônica destes terrenos e evidência dos processos de arqueamentos e falhamentos que facultaram o desenvolvimento das superfícies e níveis escalonados.

O relevo no estado do Tocantins exibe uma variada gama de feições morfológicas, resultante da evolução dos fatores morfoclimáticos e, em alguns casos, de adaptação à diversidade litológica e/ou a condicionamentos estruturais a que submeteram. A interação desses fatores resultou na presença de diversas superfícies distribuídas em níveis altimétricos diferenciados, constituindo quatro compartimentos geomorfológicos: 
- Planície do Bananal: unidade de relevo circunscrita à ampla faixa que abrange os depósitos quaternários recentes consolidados da formação Bananal e os sedimentos inconsolidados holocênicos. Nesta área inclui-se a llha do Bananal, isolada pelos rios Araguaia e Javaés (ou braço menor do Araguaia), sendo que o compartimento estende-se longitudinalmente por entre o rio Araguaia e seus afluentes ultrapassando os limites da ilha, ampliando-se pelos interflúvios Tapirapé-Xavantes. Apresenta-se embutida nas depressões do Araguaia-Tocantins, com as quais coalesce ou por vezes faz contato geomorfológico através de ressaltos topográficos;

- Planaltos da bacia sedimentar São Franciscana: refere-se a uma estreita e alongada faixa disposta em sentido norte-sul que acompanha quase toda a fronteira leste do estado. Compreende uma superfície que se prolonga para o estado da Bahia e delimita-se a oeste com as depressões do Araguaia-Tocantins através de escarpas desdobradas que formam patamares escalonados que dão acesso à Chapada das Mangabeiras;

- Depressões do Araguaia-Tocantins: esta unidade de relevo representa a união das depressões abertas pelas drenagens dos rios Araguaia e Tocantins que se encontram delimitadas por escarpas festonadas, ressaltos topográficos e/ou superfícies rebaixadas por erosão dos planaltos que as circundam, entre eles o planalto dos Parecis, planaltos da bacia sedimentar do São Francisco e o planalto Goiano, com o qual se interpenetra.

As depressões do Araguaia-Tocantins envolvem em seu interior uma série de relevos residuais do tipo inselbergue, além de um extenso conjunto serrano que compõe a unidade de relevo dos planaltos do interflúvio Araguaia-Tocantins;

- Planaltos Residuais do Interflúvio Araguaia-Tocantins: interpenetrados e circundados pelas depressões homônimas, apresentam altitude média entre 360 e $600 \mathrm{~m}$ e representam um conjunto de diversos residuais interpostos nos interflúvios AraguaiaTocantins conhecidos pelos topônimos de serras do Estrondo, Lajeado, do Carmo, Malhada Alta, Maria Antônia e do Paraíso. Estas serras configuram-se em patamares desdobrados, parte deles representando a borda da província sedimentar do Parnaíba e parte inserida na área de domínio morfoestrutural de cratons, faixas de desdobramentos e maciços antigos, apresentando litologias que vão desde o précambriano ao devoniano. A diversidade litológica reflete no relevo através da esculturação em diversas formas, a exemplo das frentes de cuestas que formam as bordas das serras do Estrondo e Lajeado, constituídas por rochas areno-argilosas da 
formação Pimenteiras, onde a erosão remontante festonou e a drenagem modelou canyons na transposição das escarpas.

À exceção das serras do Estrondo e do Paraíso as demais constituem marcos paisagísticos presentes ao longo da maior parte da área pesquisada pelo PRAL, contribuindo, em certos casos determinando, a estruturação da divisão proposta para a área de pesquisa em seções paisagísticas, como será descrito adiante.

Quanto ao solo, destacam-se na região estudada os latossolos (latossolo amarelo, latossolo vermelho-amarelo, latossolo vermelho escuro e latossolo roxo), que se caracterizam pela profundidade, boa drenagem, porosidade, textura entre média a muito argilosa e presença significativa de óxido de ferro na sua composição.

Com relação ao clima, o grande afastamento do estado do Tocantins em relação ao Oceano Atlântico reduz muito as influências marítimas e permite que a ampla extensão latitudinal defina as linhas de variação espacial da temperatura. Assim sendo, as situações de estabilidade com tempo ensolarado, muito quente no verão e ameno no inverno, não estão muito sujeitas às bruscas mudanças acarretadas pela invasão de distintos sistemas de circulação atmosférica ou correntes perturbadas de diversas direções.

Desta forma, devido à ausência de invasões de ar frio de origem polar durante o semestre primavera-verão, temperaturas próximas de $40^{\circ} \mathrm{C}$ são registradas quase que diariamente neste período, sobretudo na primavera, ocasião em que os raios solares passam pelos paralelos da região dirigindo-se para o sul e a estação chuvosa ainda não se iniciou.

\subsection{As SEÇÕES PAISAGÍSTICAS NA ÁREA DO PRAL}

Estabelecidas para operacionalizar os trabalhos de prospecção e resgate arqueológico no trecho contínuo de aproximadamente $180 \mathrm{~km}$ de extensão compreendido entre o médio e o baixo curso do rio Tocantins, as seções paisagísticas foram definidas segundo a estrutura de elementos como formas de relevo, geologia, padrões de drenagem, solos e vegetação (De Blasis \& Robrahn-González 2003). Em número de 4, sua distribuição pode ser visualizada no mapa 2 e características gerais descritas a seguir. 


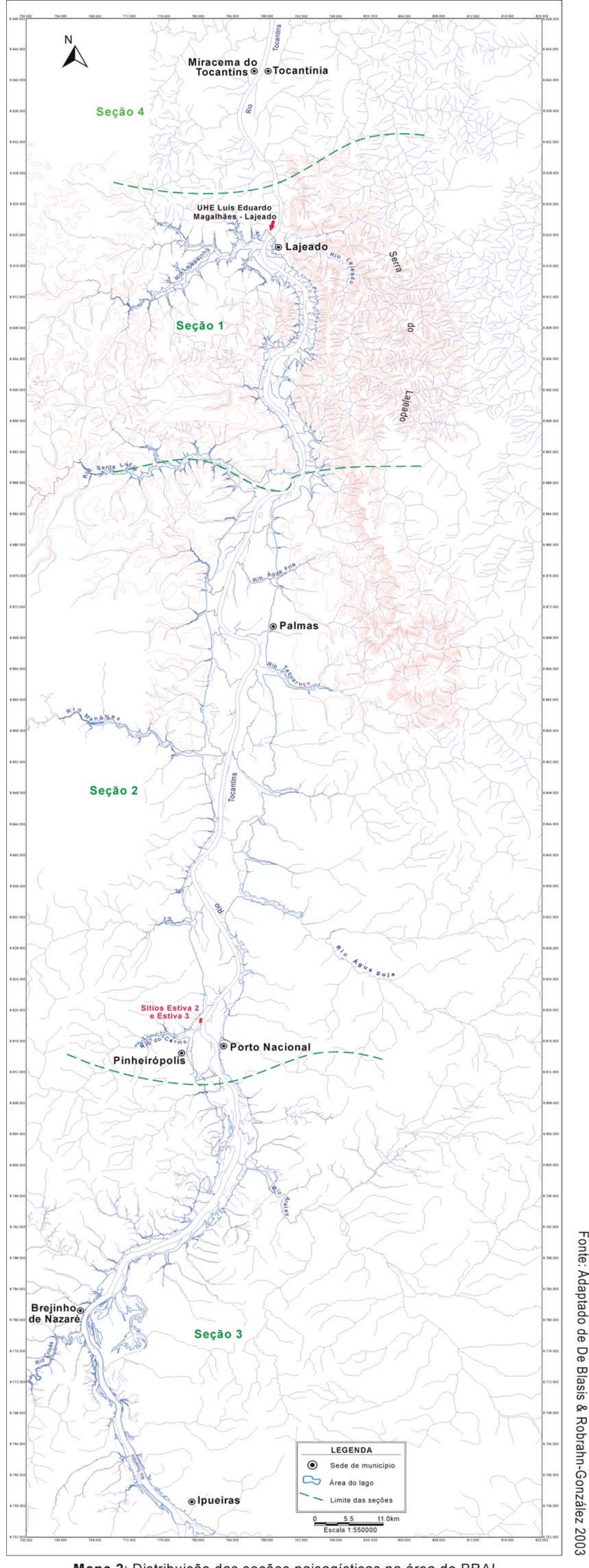

Mapa 2: Distribuição das seções paisagísticas na área do PRAL 
A primeira seção compreende o trecho entre o eixo da barragem da UHE Lajeado e a bacia do córrego Mirindiba, tributário da margem direita do rio Tocantins. Esta seção caracteriza-se pela presença imponente da escarpa arenítica denominada serra do Lajeado, parte do compartimento geomorfológico dos Planaltos Residuais do Interflúvio AraguaiaTocantins, que segue paralelamente à margem direita do rio "espremendo" seu vale juntamente com os morros residuais da margem oposta, conhecidos como serra dos Pilões (fotos 1 e 2). Neste trecho o Tocantins segue veloz por uma série de corredeiras até que na altura da foz do ribeirão Lajeado, seu mais importante afluente neste trecho, atravessa as escarpas e segue rumo ao norte num patamar planáltico mais rebaixado.

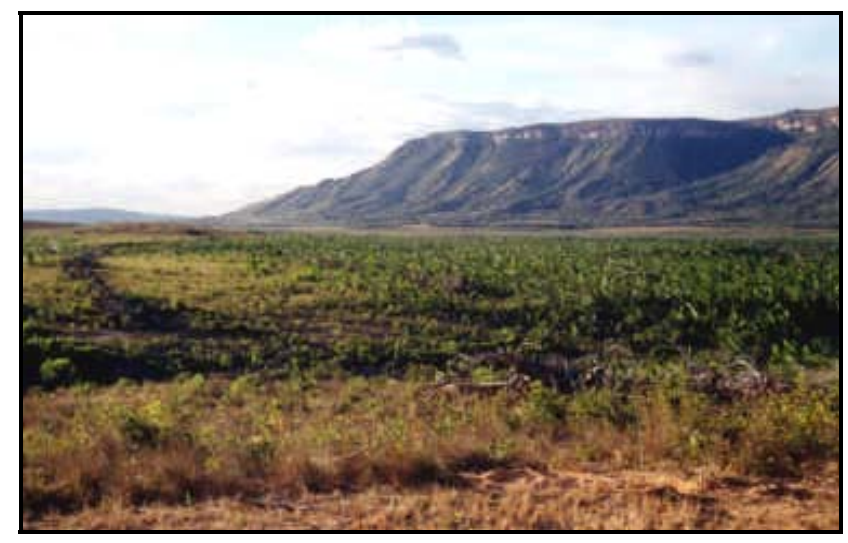

Foto 1: Serra do Lajeado

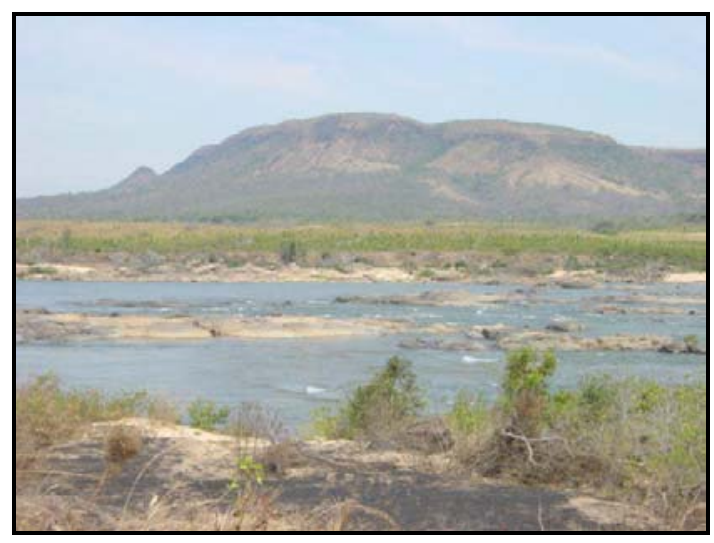

Foto 2: Serra dos Pilões

Durante o período de seca as águas recuam expondo grandes cascalheiras e barrancos nas margens do rio, as planícies aluviais (compostas pela atual planície de inundação e terraços fluviais) atingem sua maior extensão e nos vales encaixados surgem afloramentos graníticos que possibilitam a travessia de uma margem à outra do rio a pé. Aliados ao surgimento de ilhas e bancos de areia tais afloramentos tornam impossível a navegação em alguns trechos do Tocantins, além de possuírem em diversos lajedos várias gravuras rupestres identificadas nos trabalhos de prospecção do PRAL (De Blasis \& Robrahn-González 2003; Robrahn-González \& De Blasis 1997 - fotos 3 e 4).

Já durante o período chuvoso o rio Tocantins torna-se caudaloso e nestes mesmos vales encaixados segue veloz por entre corredeiras e desníveis típicos dos rios planálticos, permanecendo submersas as cascalheiras e os afloramentos areníticos e graníticos. Nesta seção, além do ribeirão Lajeado, tributário da margem direita, destacam-se como afluentes da margem esquerda o ribeirão Lajeadinho e o córrego Mares. 


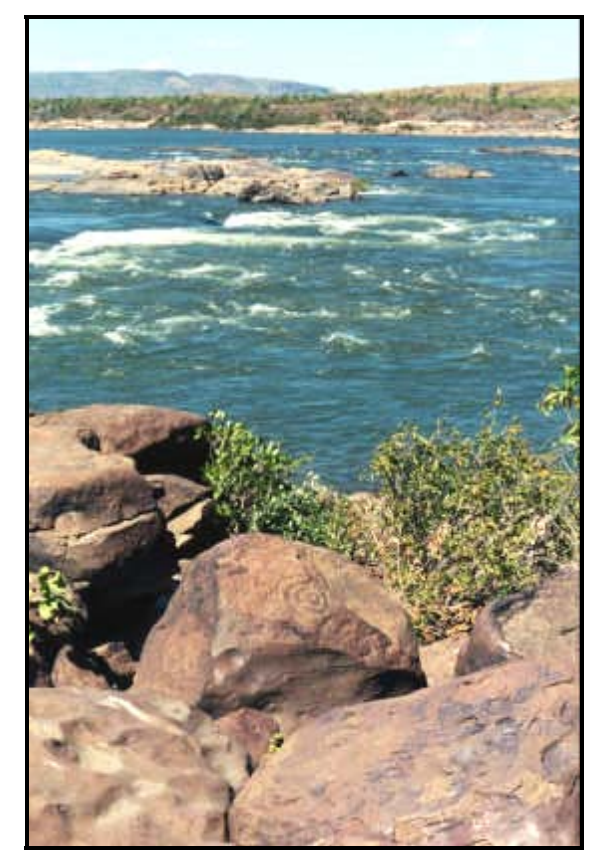

Foto 4: Gravura rupestre identificada em lajedo às margens do Tocantins

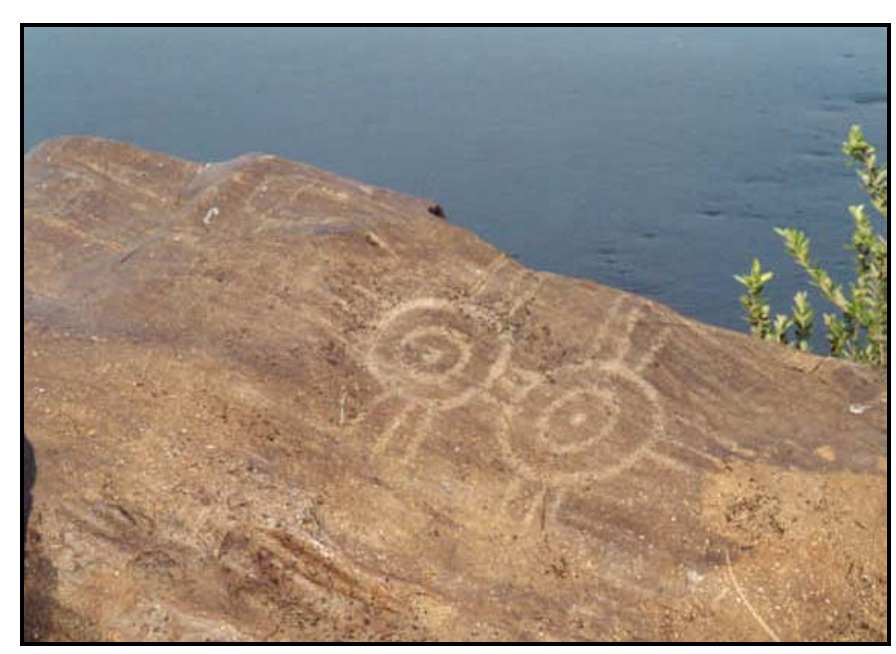

Foto 3: Afloramentos graníticos em trecho de corredeiras

$\mathrm{Na}$ região do município de Miracema do Tocantins, ao norte do eixo da barragem, enquanto que na margem direita do rio a serra do Lajeado deixa de ser um marco paisagístico, na margem esquerda existem uma série de paleodunas estabilizadas sob os afloramentos areníticos residuais que imprimem à paisagem um relevo colinar suave e arredondado e que se estendem para o sul até as planícies próximas da capital Palmas (fotos 5 e 6). Esta é a quarta seção paisagística da área de pesquisa, cujo extremo norte encontra-se na área de influência (Al) do empreendimento.

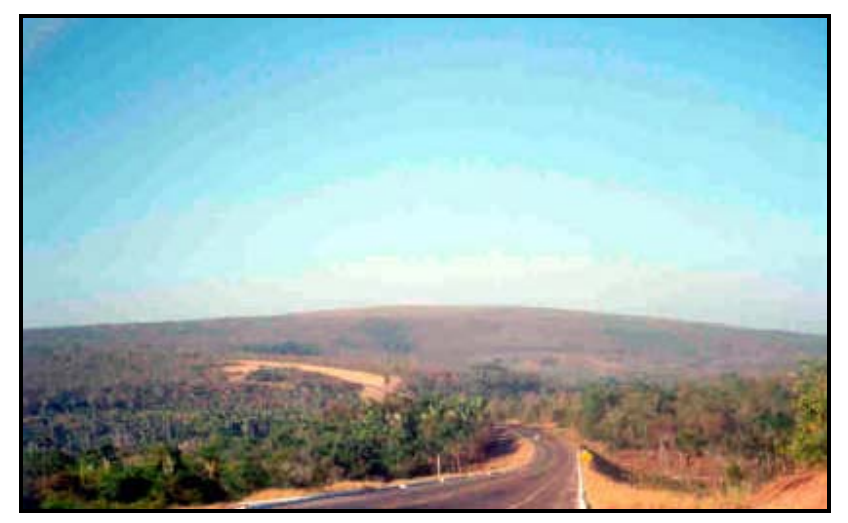

Foto 5: Aspecto geral do relevo colinar na margem esquerda do Tocantins
Foto 6: Detalhe do perfil de uma paleoduna

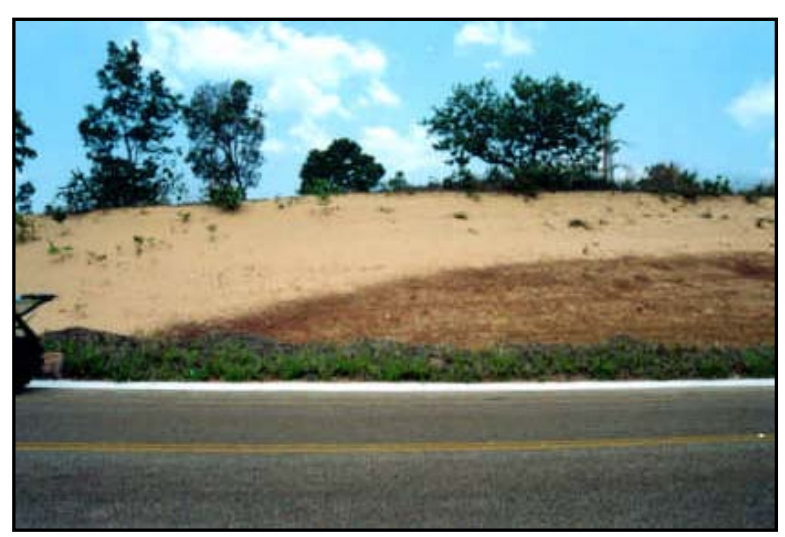


A segunda seção situa-se na porção central da área pesquisada, entre o córrego Mirindiba e o município de Porto Nacional. À medida que se segue para sul a serra do Lajeado progressivamente afasta-se do rio Tocantins em direção leste, até finalmente ceder o domínio da paisagem para uma série de micro-bacias dos afluentes que cobrem a extensa planície aluvial do Tocantins em ambas as margens, tais como os ribeirões Santa Luzia, Capivara, Porteiras e os rios Mangues e do Carmo na margem esquerda e os ribeirões Jaú, Água Fria, Taquaruçu, São João e o rio Água Suja na margem direita (foto 7). A vegetação predominante é o cerrado típico.

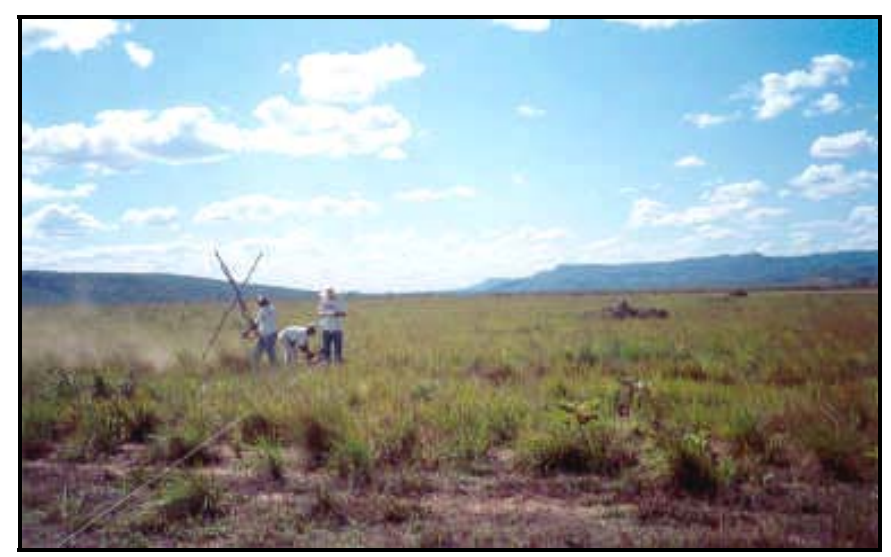

Foto 7: Planície aluvial do Tocantins na região do ribeirão Jaú. Ao fundo e a direita observa-se a serra do Lajeado

A grande dinâmica do rio Tocantins pode ser aí visualizada, pois nesta grande planície aluvial observam-se inúmeros compartimentos morfológicos distintos, relacionados possivelmente com mudanças na disposição e padrão do canal fluvial ao longo do tempo. Desta forma é comum a ocorrência de áreas hoje alagadas que representam braços mortos e meandros abandonados, assim como a presença de antigos depósitos de canais e diques marginais (Brochier 2002).

Neste contexto encontram-se os sítios estudados neste trabalho, Estiva 2 e Estiva 3 (foto 8). Ambos localizam-se às margens do córrego Estiva, um pequeno afluente da margem esquerda do rio Tocantins, em cuja área predomina a vegetação de cerrado e cerradão.

Foto 8: Aspecto geral do relevo na região onde se localizam os sítios Estiva 2 e Estiva 3. Ao fundo vê-se o rio Tocantins

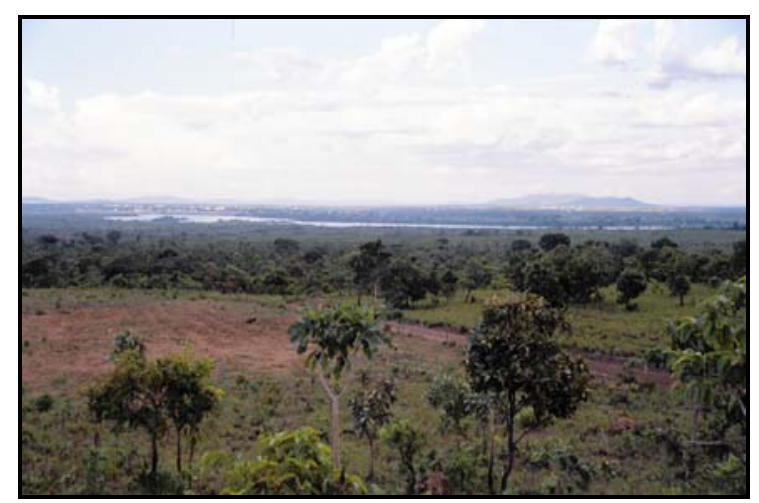


Por fim, a terceira seção paisagística do PRAL estende-se do limite sul de Porto Nacional até a cidade de Ipueiras, no fim do reservatório da UHE Lajeado. Neste setor as áreas inundadas são proporcionalmente menores que nas demais seções, a serra do Lajeado já não mais é avistada na margem direita do Tocantins, restando somente alguns morrotes isolados em meio à planície (fotos 9 e 10). O tributário mais importante que o Tocantins recebe nesta seção é o rio Crixás, além dele merecem menção os córregos Vidros, Conceição e Cipó.

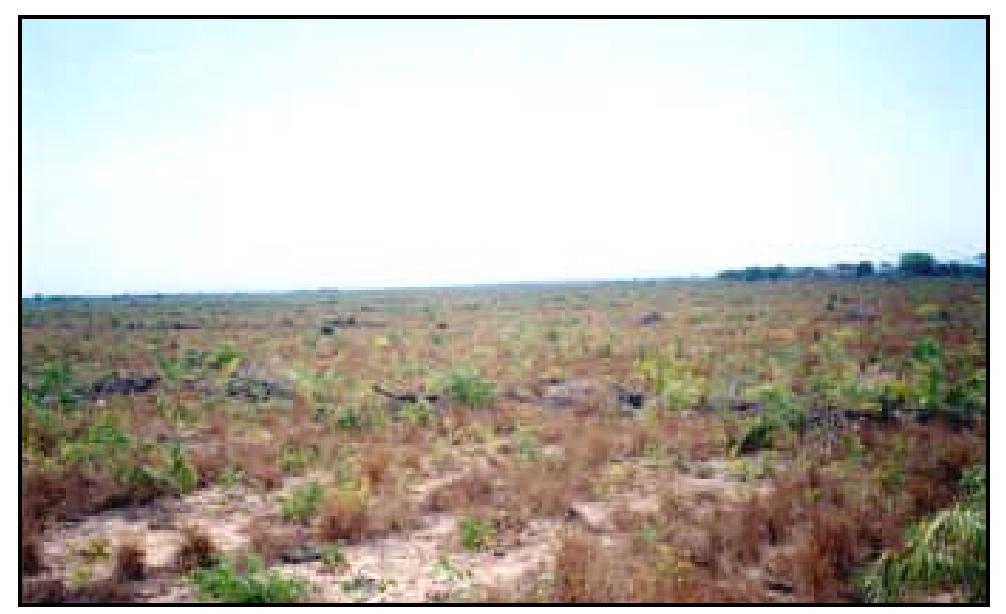

Foto 9: Aspecto geral das grandes planícies que tomam conta do cenário na terceira seção paisagística

Foto 10: Planície e morrotes isolados na região do município de Brejinho de Nazaré, terceira seção paisagística

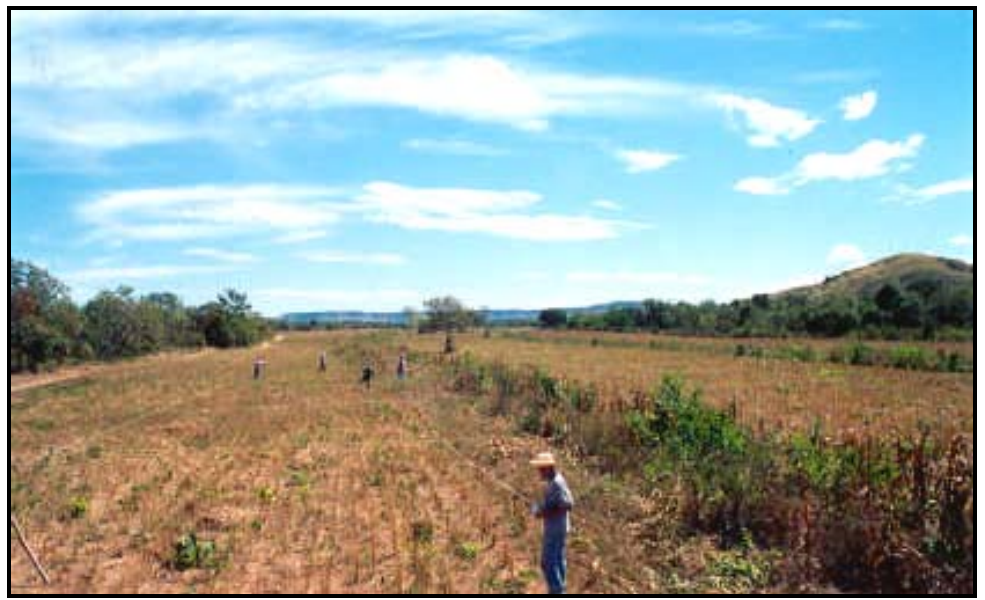




\section{CAPítulo III}

O CONTEXTO DE OCUPAÇÃO REGIONAL DOS GRUPOS CERAMISTAS

A

pesquisa arqueológica sistemática na macro-região do Brasil Central iniciou-se na década de 1970. Nos estados de Tocantins e Goiás ela se processou através, principalmente, do Programa Arqueológico de Goiás coordenado pelo Prof. Dr. Pedro I. Schmitz e desenvolvido através de convênio entre o Instituto Goiano de Pré-História da Universidade Católica e a UNISINOS. Iniciado em 1972, este Programa englobou vários projetos paralelos, cujo objetivo final era basicamente a obtenção de um primeiro quadro cronológico da ocupação humana pré-colonial através da identificação extensiva de sítios e da classificação em tradições e fases do material identificado (Barbosa et al. 1976/77a, 1976/77b, 1982; Miranda 1980; Moehlecke et al. 1976/77; Schmitz 1976/77, 1980, 1996; Schmitz \& Barbosa 1985; Schmitz et al. 1974/75, 1979, 1981/82, 1982).

Na mesma época a Universidade Federal de Goiás desenvolveu em parceria com o Museu Paulista da Universidade de São Paulo o Projeto Anhangüera de Arqueologia, que sob a coordenação da Profa. Dra. Margarida Andreatta objetivou a escavação de alguns sítios e a obtenção de cronologias (Andreatta 1982, 1988).

Na década de 1980 I. Wüst desenvolveu pesquisas na área do "Mato Grosso de Goiás", região localizada na porção central do estado de Goiás, com proposta teóricometodológica voltada a problemas de cunho antropológico, onde a análise do padrão de distribuição espacial dos sítios, aliada a distribuição dos recursos na paisagem, permitiu a construção de hipóteses sobre o processo de ocupação humana desta área (Wüst 1981/82, 1983, 1991). Esta mesma pesquisadora atua desde a década de 1990 no sul-sudeste do estado do Mato Grosso coordenando pesquisas sistemáticas que, através dos aspectos morfológicos e de implantação na paisagem dos sítios, pretenderam encaminhar questões relativas às continuidades e/ou mudanças nestas sociedades pré-coloniais (Wüst 1990, 1998, 1999; Wüst \& Barreto 1999).

Seguindo esta linha de pesquisa encontra-se o já mencionado trabalho de RobrahnGonzález (1996a), que considerando a existência tanto de influências internas quanto 
externas para explicar as origens e o desenvolvimento dos grupos ceramistas, propõe ter sido o Planalto Central uma "área de confluência para deslocamentos de informações, objetos e/ou pessoas relacionados a grupos ceramistas, oriundos das regiões circunjacentes em período pré-colonial".

No estado do Mato Grosso do Sul estão também em andamento pesquisas sistemáticas, onde o levantamento e o estudo dos sítios, incluindo os em aterro, na região do Pantanal tem revelado dados sobre a ocupação humana neste ambiente e suas relações com a região chaquenha especialmente (Migliácio 2000, Oliveira 1995; Peixoto 2003, 1995; Veroneze 1993, entre outros).

Além dos projetos acadêmicos, gradativamente mais regiões do Planalto Central tem sido objeto de pesquisas arqueológicas relacionadas a Estudos de Impacto Ambiental (EIARIMA), o que a longo prazo, com a publicação dos dados levantados, permitirá ampliar o conhecimento acerca das ocupações humanas nos mais variados ambientes desta macroregião. Entre os inúmeros trabalhos concluídos ou em andamento (um quadro bastante amplo com tais projetos, seus objetivos, coordenação, área de atuação e andamento das pesquisas pode ser encontrado em Oliveira \& Viana 1999/00), destaca-se também por ter vinculado às atividades de resgate projetos acadêmicos de pesquisa com objetivos próprios o Projeto de Salvamento Arqueológico da UHE Serra da Mesa (Martins 1998), ao qual estão relacionadas duas teses de doutoramento (Martins 1999, Souza 2003) e uma dissertação de mestrado (Pontim 2004).

Em comum, todos os projetos desenvolvidos no Brasil Central têm revelado o potencial arqueológico desta macro-região através da constatação empírica da diversidade e do alcance geográfico da ocupação humana. Como aponta Robrahn-González (1996a), o Planalto Central é a única região no Brasil que aglutina vestígios arqueológicos relacionados às demais porções do país.

Para a contextualização regional desta pesquisa foram utilizados os trabalhos de Robrahn-González (1996a, 1996b) por fornecer um quadro de referência regional para a ocupação de grupos ceramistas segundo a análise relacional entre padrões de elementos tais como indícios de contatos culturais, áreas de ocorrência, diversidade, natureza e cronologias das ocupações. A partir destas análises a autora indica a existência de 7 grupos culturais (sem vínculos com etnias específicas) na região do Brasil Central, perspectiva com a qual se situam os assentamentos aqui estudados.

Os sítios identificados pelo PRAL relacionam-se a quatro destes grupos, o denominado das "grandes aldeias do leste", o das "grandes aldeias do oeste", o das "aldeias do centro-norte" e o Tupiguarani, sendo que esta pesquisa trabalha especificamente dentro da perspectiva dos três primeiros grupos, motivo pelo qual apenas estes terão suas características principais aqui detalhadas. 


\subsection{A ARQUEOLOGIA DAS ALDEIAS CIRCULARES}

Em torno do ano 800 AD o Brasil Central começa a ser gradativa e maciçamente ocupado por grupos ceramistas que viviam em grandes aldeias de morfologia circular com até mais de $500 \mathrm{~m}$ de diâmetro e formadas por 1 a 3 anéis concêntricos de habitações em cujo interior havia uma grande praça central. O debate acerca do surgimento e desenvolvimento destas aldeias permanece em aberto, contudo, a maioria dos pesquisadores tende a concordar que a emergência destas aldeias esteve relacionada ao menos a dois fluxos migratórios distintos: uma frente pioneira do leste que ocupou todo o centro-sul de Goiás estendendo-se em direção ao valo do São Francisco e para cujo conjunto material atribuiu-se a denominação de tradição Aratu; e uma frente posterior do oeste, que ocupou o estado do Mato Grosso e ficou conhecida como tradição Uru.

Não se sabe ao certo a origem destes grupos, contudo, quando da ocupação do Planalto Central teve curso uma série de mudanças e adaptações no cenário regional, pois mesmo possuindo características culturais distintas, ambos os grupos tinham na aldeia circular uma mesma estratégia de estruturação e organização da sociedade que foi amplamente implantada na região.

Esta configuração da organização do espaço permanece até os dias de hoje entre sociedades indígenas filiadas ao tronco lingüístico Jê como os Kayapó, os Bororo e os Xavante e estão relacionadas a concepção holística de organização da própria vida destas sociedades. Todavia, esta mesma conformação deturpou durante muitos anos a visão que muitos antropólogos e arqueólogos tinham acerca destas sociedades, consideradas igualitárias e sem estratificação aparente, a variabilidade no uso do espaço nas aldeias e a hierarquia interna eram tidas como ausentes no espaço aparentemente igualitário do círculo de casas da aldeia.

Tal visão começou a ser dilapidada apenas a partir dos trabalhos de Maybury-Lewis (1979), Nimuendajú (1942), Turner (1979a, 1979b) entre outros, que demonstram a complexidade da estrutura hierárquica destas sociedades apesar da aparente igualdade que a aldeia de morfologia circular parece encerrar em si. Na arqueologia, apenas em fins da década de 1980 pesquisas desenvolvidas na área começaram a detectar variações espaciais na distribuição dos vestígios nos sítios arqueológicos identificados como aldeias circulares que poderiam relacionar-se a diferenças sociais e políticas presentes nestes grupos (Wüst 1983, 1990, Wüst \& Carvalho 1996). 


\subsubsection{As grandes aldeias do leste}

Relacionados à tradição Aratu, cuja área de ocorrência abrange os estados do Piauí, Maranhão, Bahia, Minas Gerais, Goiás e São Paulo, estes grupos encontram-se por toda a região centro-sul-sudeste de Goiás, tendo o vale do Araguaia como limite oeste de ocupação e o médio vale do Tocantins como limite setentrional. Ocuparam de forma intensa o Planalto Central entre os séculos VIII e IX, espalhando por este vasto território as extensas aldeias circulares que constituem seus assentamentos, com algumas podendo alcançar até mesmo 500 metros de diâmetro, formando 1, 2 ou 3 anéis concêntricos de ocupação ao redor de uma praça central vazia.

A origem destes grupos é duvidosa, muito embora alguns arqueólogos especulem que estejam relacionados a grupos externos ao Brasil Central. Constituem a primeira ocupação em grande escala do Planalto Central e caracterizam-se pela grande permeabilidade a influências externas em contrapartida de certa homogeneidade interna (Robrahn-González 1996a, Wüst 1990).

Em linhas gerais, a indústria cerâmica destes grupos apresenta vasilhames cônicos, globulares e semi-globulares de contorno simples e infletido (com predominância de contorno simples) de grande volume. O antiplástico utilizado mais comumente é o mineral e a presença de motivos decorativos (plásticos ou pintados) é muito rara. Documentou-se também a presença de fusos, cachimbos tubulares e formas duplas. Tais características levaram arqueólogos a especular que estes grupos possuíam no cultivo do milho uma de suas principais fontes de subsistência (Schmitz et al. 1982).

A partir dos séculos $X$ e XI nota-se nos sítios um aumento na presença de peças relacionadas a outros grupos (Tupiguarani e Uru) e a adoção cada vez maior de elementos tecnológicos destes nos artefatos cerâmicos, assim como variações consideráveis no tamanho, forma e implantação na paisagem dos sítios, fatos que indicam processos de mudança cultural profundos nestas sociedades, talvez relacionados à presença cada vez mais intensa dos grupos Uru em seu território (Wüst 1990). A partir do século XV já não são mais identificados assentamentos tipicamente Aratu na região como um todo.

Apesar das datações indicarem terem sido estes os primeiros grupos a ocupar a região do médio Tocantins, esta ocupação teria se processado no âmbito das profundas mudanças observadas em sítios no restante do Planalto Central, desta forma é necessária cautela quanto ao estudo de seus assentamentos. 


\subsubsection{As grandes aldeias do oeste}

Relacionados à tradição Uru, estes grupos ocuparam inicialmente o alto/médio Araguaia, alto Tocantins e o vale do rio São Lourenço por volta dos séculos VIII e IX. Até o século XI sua ocupação restringiu-se ao vale do rio Araguaia, quando então se iniciou uma marcha rumo leste destes grupos, que gradativamente invadiram territórios outrora ocupados apenas pelos grupos portadores da cerâmica Aratu.

Neste processo, que dura aproximadamente até o século XIV, suas aldeias anulares e lineares ocupam maciçamente o Brasil Central, muito provavelmente assimilando os grupos das aldeias do leste. Tais grupos caracterizam-se pela grande diversidade interna (Wüst 1990) aliada a pouca permeabilidade às influências externas.

A indústria cerâmica caracteriza-se pela presença de tigelas rasas e pratos com bases planas em pedestal às vezes apresentando perfurações, assadores e grandes jarros, as bordas usualmente apresentam-se reforçadas, o cariapé é o antiplástico utilizado por excelência. As características desta indústria cerâmica levaram arqueólogos a creditar a manufatura da mandioca brava como um dos produtos de subsistência mais importantes entre estes grupos, fato que também pode relacioná-los a contextos amazônicos uma vez que sua origem, também, é incerta (Schmitz \& Barbosa 1985; Schmitz et al. 1982).

Por volta do século XII aparentemente ocorre um grande crescimento populacional entre estes grupos (Wüst 1990), apesar de não se saber quais processos estão envolvidos neste crescimento demográfico, este com certeza contribuiu na intensificação da ocupação destes grupos em áreas a leste do Araguaia. Em contrapartida, este crescimento pode ter proporcionado um incremento interno com uma maior organização das aldeias.

\subsubsection{As aldeias do centro norte}

Com a expansão da ocupação dos grupos do oeste do Araguaia para o leste e o conseqüente contato destes com os grupos originalmente aí estabelecidos, surgiu uma "área de contato" imediato localizada entre os alto/médio rios Araguaia e Tocantins, onde a presença de assentamentos cuja indústria associada é um misto de elementos Aratu e Uru predomina. Estes assentamentos caracterizariam o surgimento de um novo grupo, denominado de "agricultores do centro-norte".

Os sítios do médio Tocantins parecem indicar que à expansão oeste-leste dos grupos portadores da cerâmica Uru teria se sucedido, em período tardio (séculos XIV e XV), uma expansão sentido sul-norte pela bacia do Tocantins, cujo limite de ocorrência seria a 
confluência Araguaia/Tocantins. O médio Tocantins seria, portanto, a área mais setentrional de ocorrência destes agricultores do centro-norte, uma vez que a expansão Aratu também possuía este limite.

\subsection{OS GRUPOS CERAMISTAS NO MÉDIO CURSO DO RIO TOCANTINS}

Até meados da década de 1990, enquanto que no alto curso do rio Tocantins um quadro geral da ocupação dos grupos ceramistas se delineava a partir dos resultados obtidos pelo Projeto de Salvamento Arqueológico da UHE Serra da Mesa (Martins 1998) e no baixo curso dados obtidos na década de 70 , durante o resgate arqueológico na área afetada pela construção da UHE Tucuruí, indicavam a presença de assentamentos relacionados à tradição Tupiguarani datados em torno do ano 1000 de nossa era (AraujoCosta 1983; Simões \& Araujo-Costa 1987), para o médio curso havia apenas a descrição de quatro sítios identificados pelo "Projeto Médio Tocantins", parte do Programa Arqueológico de Goiás coordenado pelo professor Pedro I. Schmitz, que estabeleceu os parâmetros para a definição da fase cerâmica Pindorama (Barbosa et al. 1982).

\subsubsection{A ocupação ceramista na área do PRAL}

À exceção dos quatro sítios identificados pelo Prof. Dr. Pedro I. Schmitz em 1978 na região de Monte do Carmo, a leste da cidade de Porto Nacional, a bacia do médio rio Tocantins permanecia arqueologicamente desconhecida até o início das investigações sistemáticas realizadas pelo PRAL no setor impactado pela construção da UHE Lajeado. Tal programa de resgate foi decisivo, pois, para a construção de um primeiro quadro relativo ao modo como se processou a ocupação humana nesta porção do vale do Tocantins.

Especificamente com relação aos grupos ceramistas, o conjunto material referente aos 120 sítios identificados pelo PRAL permitiu relacionar esta ocupação no médio vale do rio Tocantins ao contexto arqueológico regional do Brasil Central uma vez que as indústrias arqueológicas apresentam atributos relacionáveis a quatro tradições ceramistas com área de ocorrência nesta macro-região: Una, Aratu, Uru e Tupiguarani.

Os aspectos gerais identificados na ocupação destes grupos na área estudada foram:

- quanto à implantação na paisagem, os assentamentos localizam-se nos terraços próximos a cursos d'água, desde córregos até às margens do próprio Tocantins, 
tanto em área de cerrado quanto em área de mata. Os sítios apresentam-se de forma generalizada pela área de pesquisa, estando presentes em todas as seções paisagísticas à exceção da região extremo norte ou quarta seção;

- quanto à morfologia os sítios possuem duas configurações básicas: 1) grandes áreas de dispersão de material dispostas seja em forma circular, elipsoidal ou irregular, que correspondem a aldeias de médio/grande porte compostas por diferentes unidades habitacionais; 2) áreas de dispersão pequenas, alcançando no máximo 50m de diâmetro, formando uma única concentração de vestígios que sugerem acampamentos ou áreas de atividades específicas relacionadas às grandes aldeias;

- todos os sítios são caracterizados pela superficialidade do pacote arqueológico, que varia de 25 a $30 \mathrm{~cm}$ de profundidade. Esta configuração, aliada à intensa utilização do solo para fins agrícolas prejudicou sobremaneira a conservação dos mesmos, restringindo a possibilidade de realização de pesquisas intra-sítio para algo em torno de $20 \%$ do total de sítios identificados;

- quanto às características das indústrias associadas, a maior parte dos 120 sítios identificados relacionam-se às tradições Aratu e Uru, quantitativamente menos expressivos encontram-se os relacionados ao horizonte Tupiguarani. Não foram identificados sítios relacionados à tradição Una, sua presença na área restringese a poucas peças encontradas em alguns abrigos sob-rocha e a ocorrências isoladas na margem direita do Tocantins, na altura do eixo da barragem;

- embora poucos tenham sido os sítios que forneceram amostras confiáveis de carvão, as datações obtidas situam o médio Tocantins como uma ocupação tardia destes grupos ceramistas se comparada com a cronologia dos mesmos no Brasil Central propriamente dito. As datas indicam os séculos XII da nossa era para a tradição Aratu, XIV e XV para o horizonte Uru e XV para a ocupação relacionada à tradição Tupiguarani na área;

- padrão recorrente é a presença de componentes de duas ou três tradições em um mesmo sítio, indicada seja pela confecção dos artefatos (vasilhas de formas típicas Aratu que possuem antiplástico característico da tradição Uru, por exemplo), quanto pela existência de pequenas concentrações de artefatos cuja manufatura difere do restante do material identificado no assentamento (peças da tradição Uru em setores de sítios tipicamente Aratu). A associação mais comum identificada nos sítios da área de pesquisa foi a ocorrência de material Uru em sítios Aratu. 
Quanto a este último aspecto, os sítios da fase Pindorama (Barbosa et al. 1982) já haviam revelado esta característica, que pode relacionar-se à ocupação em diferentes momentos de uma mesma área por grupos distintos (sobreposição) ou corresponder à ocupação, simultânea ou não, de uma mesma área por diferentes grupos.

A segunda situação remete a fenômenos de interação culturais amplos, como a manutenção de redes internas e/ou externas de troca de bens, pessoas e/ou idéias ou mesmo a fusão gradativa de grupos culturais portadores de indústrias cerâmicas diversas. Todavia, seja qual for sua natureza, este fenômeno revela uma complexa dinâmica cultural, social e política presente nestas sociedades pretéritas (Wüst 1983, 1990).

$\mathrm{Na}$ região centro-norte do Brasil Central, especificamente no alto curso dos rios Araguaia e Tocantins, como já mencionado, foi identificada uma gradativa fusão entre a cultura material das tradições Aratu e Uru a partir do século $X$ e até o século $X V$, sendo que o predomínio tecnológico permaneceu da tradição Uru (Robrahn-González 1996a, 1996b; Wüst 1999). Considerando as poucas datações obtidas para os sítios da área de pesquisa, entre os séculos XII e XV, vê-se que estão situados neste período, caracterizado como tardio e de intensa mudança na estrutura interna destas sociedades. 


\section{Capítulo iv}

OS SÍTIOS ARQUEOLÓGICOS

\subsection{O TRABALHO DE CAMPO}

$\AA_{\text {s etapas de campo para o resgate de sítios filiados a ocupações ceramistas }}$ foram organizadas no âmbito do PRAL de modo a propiciar um quadro amplo acerca da ocupação destes grupos na porção estudada do médio Tocantins. Desta forma, os sítios a serem resgatados foram selecionados de modo a cobrir amostralmente toda a área de pesquisa, para tanto foi utilizado como parâmetro a localização destes nas quatro seções paisagísticas propostas para a área (mapa 2).

Deste modo, no âmbito da terceira etapa do Programa foram realizadas 4 campanhas de campo nos cenários das segunda e terceira seções. O enfoque destas campanhas foi a escavação sistemática de sítios relacionados a ocupações de grupos ceramistas, tendo como resultado o mapeamento intra-sítio de 10 assentamentos précoloniais, entre os quais os sítios Estiva 2 e Estiva 3 aqui analisados.

A primeira medida adotada em campo foi a seleção dos sítios a serem trabalhados. Primeiramente foram avaliadas as informações sobre localização, dimensão aproximada, tipos de vestígios associados, visibilidade do solo e o grau de conservação dos sítios identificados pelas equipes de prospecção na segunda etapa do PRAL, aqueles que apresentavam um quadro favorável quanto ao estado de conservação e a visibilidade do solo foram pré-selecionados para reavaliação em campo, uma vez que em alguns casos dois anos se passaram entre uma etapa e outra. Apenas os que mantiveram características favoráveis para a realização de estudos no âmbito intra-sítio foram trabalhados.

Metodologicamente trabalhou-se a maioria dos sítios através de coletas totais de superfície por quadrículas. O procedimento básico consistiu na identificação visual da área de dispersão dos vestígios em superfície e na construção de uma malha de quadrículas de 10×10m nesta área (em todos os sítios trabalhados a área de dispersão raramente foi inferior a $200 \times 200 \mathrm{~m}$ ), onde se procedeu a coleta dos vestígios dentro dos limites de cada quadra. Simultaneamente intervenções de subsuperfície (sondagens de $1 \mathrm{~m}^{2}$ e poços-teste 
com dimensões de $0,50 \times 0,50 \mathrm{~cm}$ ) foram utilizadas como controle dos limites horizontal e vertical do registro arqueológico, sendo que nos sítios onde a cobertura vegetal não impedia a visualização completa da área do assentamento, os limites de ocorrência dos vestígios de superfície se refletiram na contra prova das intervenções de subsuperfície.

Desta forma, acredita-se que a coleta total de superfície, nestes casos, foi profícua na medida em que a configuração superficial dos materiais refletia a configuração do sítio como um todo. Assim, ainda que autores como Flannery (1976), Redman (1987), Redman \& Watson (1970) e Plog et al. (1978) valorizem o método amostral para a coleta de dados, no caso dos sítios relacionados a grupos ceramistas no médio Tocantins a coleta total de superfície (Lewarch \& O’Brien 1981) representa uma opção vantajosa no que diz respeito aos objetivos das análises intra-sítio.

Do total de sítios cerâmicos resgatados pelo PRAL 19 possuem dados que propiciam análises intra-sítio que objetivem a compreensão da maneira pela qual o espaço interno do assentamento foi utilizado pelas sociedades pré-coloniais. Distribuídos pelas diferentes seções paisagísticas da área de pesquisa, estes sítios representam um conjunto muito bem documentado sobre a ocupação ceramista no médio vale do rio Tocantins, cuja cultura material possui características passíveis de filiação com três tradições arqueológicas: Aratu, Uru e Tupiguarani. Vistos no âmbito geral do PRAL, tais sítios somaram importantes informações para a melhor compreensão da ocupação ceramista nesta área, constituindo, desta forma, acervo informativo de grande relevância, disponível para quaisquer outros pesquisadores que se interessem pelo tema.

Os sítios Estiva 2 e Estiva 3 foram selecionados para serem aqui analisados por apresentarem características favoráveis para o estudo da interação cultural entre os grupos ceramistas pré-coloniais filiados às tradições Aratu e Uru. Apresentaram um relativo bom estado de conservação, sendo que o terreno em que se encontram prestava-se à pastagem e ao cultivo familiar em roças de toco ou coivara, havendo inclusive indícios de considerável cobertura vegetal de grande porte, indicada pela presença de grande quantidade de toras recém derrubadas em virtude da formação do reservatório da usina abandonadas pelo terreno (foto 11).

Além disto, o fato de localizarem-se em uma área densamente ocupada por grupos ceramistas também favoreceu na seleção. Estes sítios encontram-se próximos da bacia do rio do Carmo, na qual se encontram implantados sítios de menor porte relacionados às tradições Aratu e Uru além de uma aldeia relacionada à ocupação Tupiguarani (sítio Estiva 1), localizada cerca de $1 \mathrm{~km}$ dos sítios aqui analisados. 


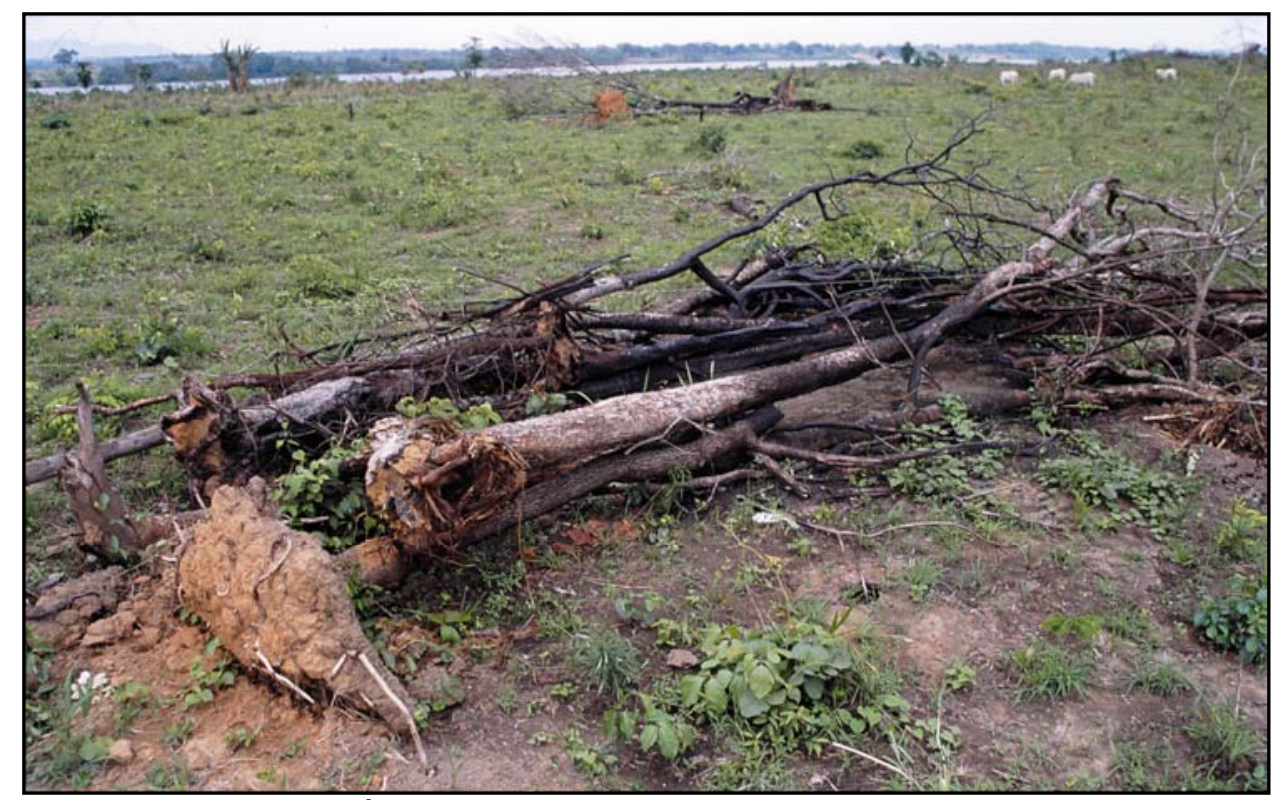

Foto 11: Árvores derrubadas no terreno do sítio Estiva 2

O mapa 3, apresentado a seguir, indica a localização dos sítios Estiva 2 e Estiva 3 a partir da "Carta geológica do Brasil ao milionésimo" (IBGE 1998), ambos encontram-se implantados em terraços fluviais na planície aluvial da margem esquerda do rio Tocantins, na altura da sede do município de Porto Nacional, domínio da segunda seção paisagística do PRAL (foto 12).

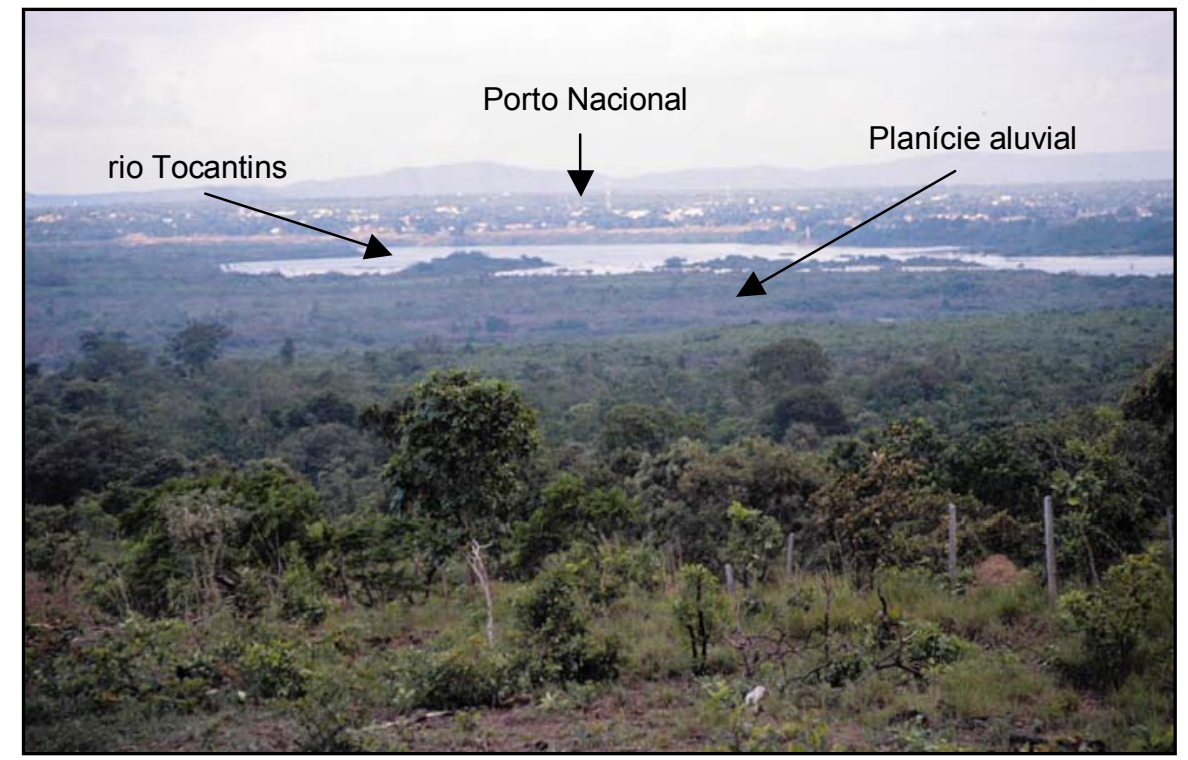

Foto 12: Implantação dos sítios Estiva 2 e Estiva 3 

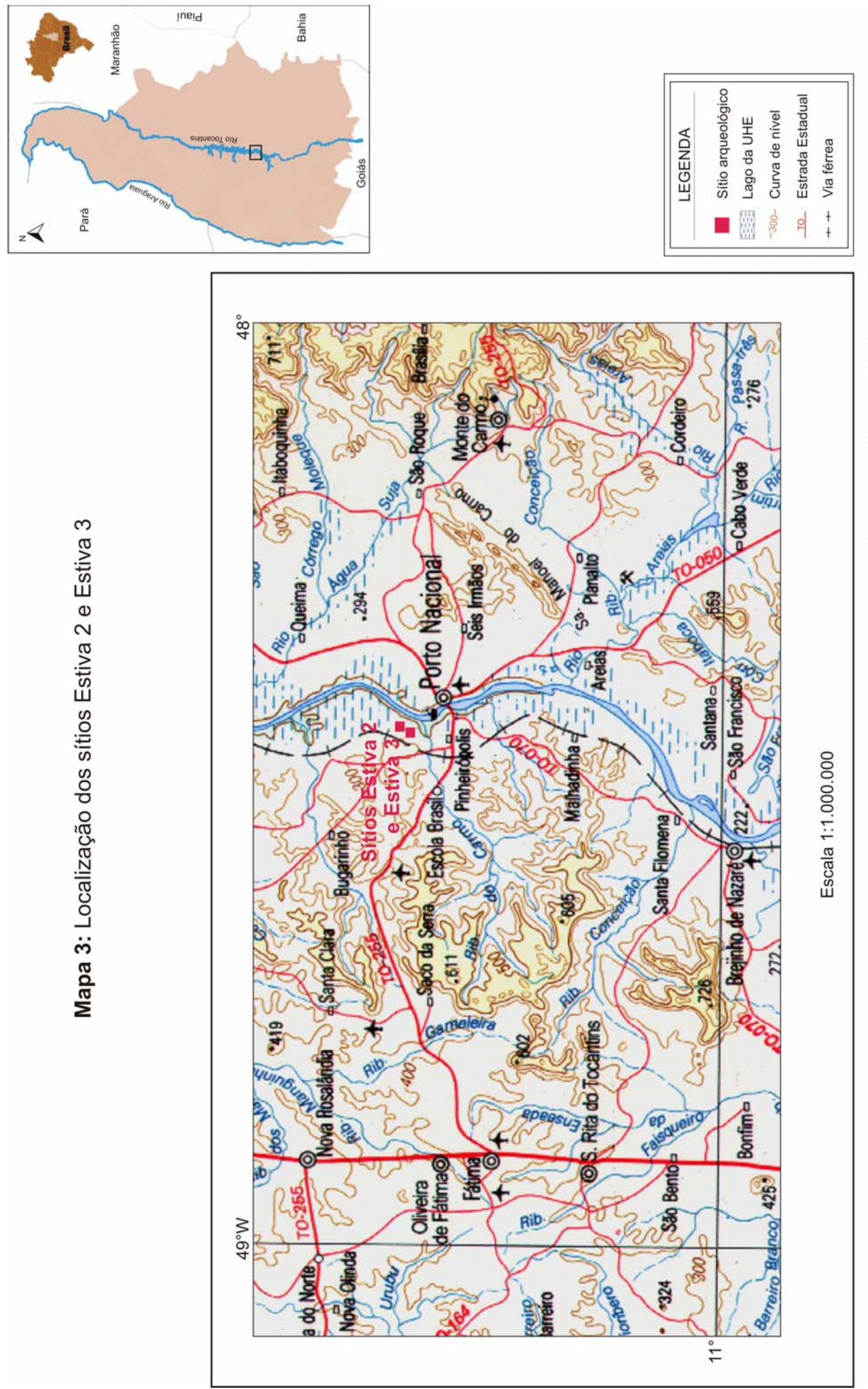


\subsection{Sítio Estiva 2 (Ev2)}

Localiza-se em antigo terraço fluvial a cerca de $200 \mathrm{~m}$ a oeste da margem esquerda do rio Tocantins e a $18 \mathrm{~m}$ da margem esquerda do córrego Estiva, um pequeno afluente do Tocantins localmente denominado brejo da Estiva. O terreno, plano no geral, apresenta suave declividade na porção oeste, em direção ao córrego, a noroeste em direção à estrada vicinal de acesso, a norte e a leste em direção ao rio Tocantins. Entre o sítio e o rio principal encontra-se um meandro abandonado deste, convertido em um brejo caracteriza-se como área alagada com vegetação rasteira abundante (figura 3).

À sudeste, próximo das ruínas de uma residência de alvenaria e de um curral, de onde se inicia um caminho de terra batida que segue na direção oeste até a estrada vicinal de acesso, foi possível visualizar entre lixo doméstico grande quantidade de material arqueológico. Também na porção nordeste, nas proximidades de uma choupana, foi identificado material cerâmico pré-colonial entre fragmentos de tijolos e louça contemporâneos. Convém esclarecer que os moradores não mais se encontravam na área quando da escavação do sítio arqueológico, de modo que não havia a quem interpelar acerca da natureza e do grau de intervenção de atividades antrópicas realizadas no terreno.

Afim de melhor caracterizar os limites da ocorrência do material em superfície foi realizada uma prospecção intensiva na área, com a equipe percorrendo ida e volta o terreno em linhas imaginárias de caminhamento, paralelas e eqüidistantes em 5 metros. Desta forma o terreno foi percorrido sistematicamente, sendo o material encontrado identificado visualmente com bandeirinhas azuis, o que permitiu a fácil observação da dispersão do material em todo o sítio (foto 13), cuja maior concentração localiza-se na parte plana mais elevada do terraço.

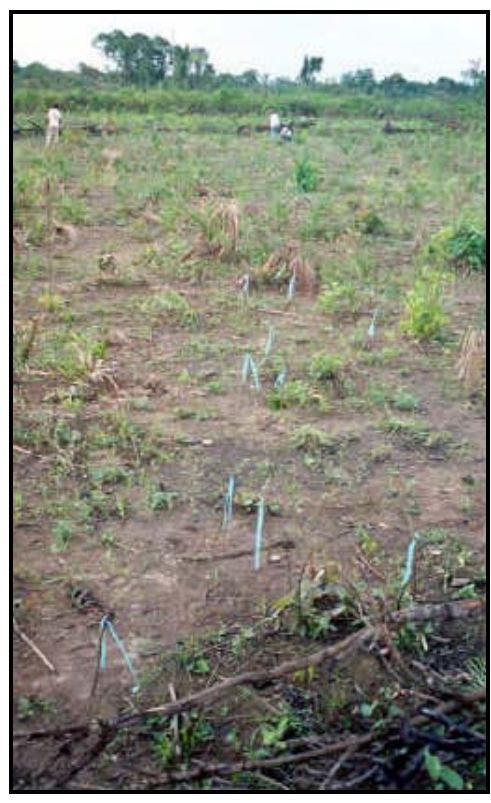

Foto 13: Detalhe da identificação do material de superfície com o auxílio de bandeirinhas azuis 
Figura 3: Croqui do sítio Estiva 2

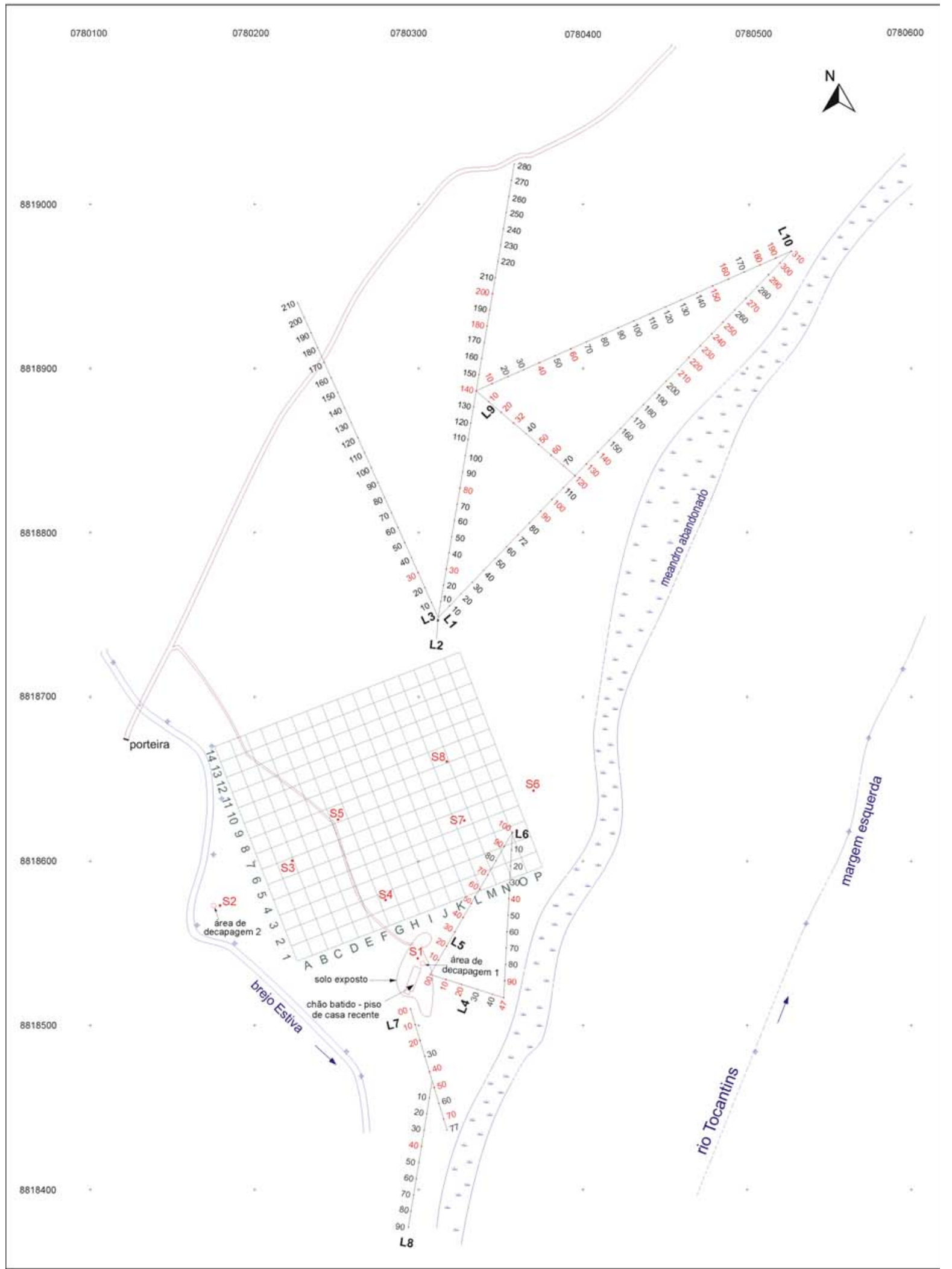

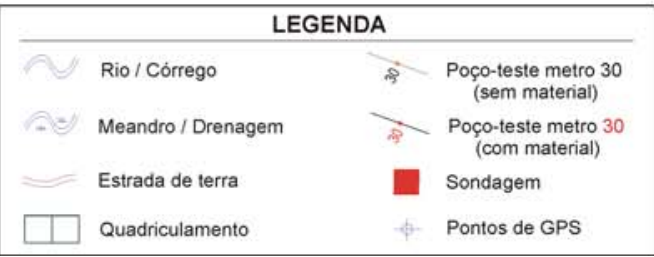

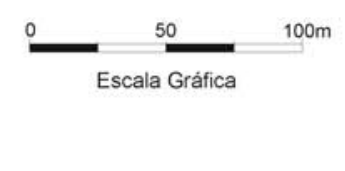

CROQUI DE CAMPO
Laercio Loiola Brochier
DIGITALIZAÇĀOO
Laercio Loiola Brochier
DIAGRAMAÇÃO E ARTE FINAL
Elisângela Regina de Oliveira 
Após este procedimento, para caracterizar com mais apuro os limites horizontal e vertical do assentamento foram posicionadas 10 linhas de poços-teste de modo a cobrir as áreas em que a observação superficial foi impossibilitada pela cobertura vegetal. Os poçosteste permaneceram eqüidistantes em 10 metros, com dimensões de 0,50 x 0,50 cm e profundidade variando entre 20 e $30 \mathrm{~cm}$. A configuração das linhas, observável na figura 3 , obedeceu ao seguinte critério:

Três linhas foram definidas no extremo norte do sítio a partir do final da concentração superficial, cobrindo daí as direções leste (L1), norte (L2) e oeste (L3). Outras três linhas foram posicionadas no estremo sul, a partir dos alicerces da casa de alvenaria em sentido leste (em direção ao meandro - L4), nordeste (L5) e unindo as anteriores L6, fechando, pois, o limite da ocorrência de material neste setor. As L7 e L8 foram posicionadas a sul destes alicerces e as L9 e L10 fecharam o setor norte, unindo o metro 140 da L2 ao metro 310 da L1 (L10) e o mesmo metro 140 da L2 ao metro 120 da L1 (L9).

No croqui do sítio (figura 3) é possível visualizar que as L1, 2, 9 e 10 captaram uma área periférica com pouca ocorrência de material localizada próxima do sítio Estiva 3 . 0 material coletado nos poços-teste desta região refere-se a poucos fragmentos cerâmicos relacionados à tradição Uru, material lítico lascado, além de algumas peças históricas (a choupana mencionada anteriormente localiza-se próxima dos metros 240 e 270 da L1). Esta área permaneceu dissociada da região de maior concentração de material do sítio Estiva 2 até que a identificação do sítio Estiva 3, durante a etapa de caminhamento, permitiu levantar a hipótese de esta ser interpretada como intermediária entre ambos.

O resultado obtido com a abertura das linhas de poços-teste possibilitou afirmar que os limites da área do assentamento são, de fato, determinados pela topografia do terreno. $\mathrm{A}$ ocorrência material se limita a leste metros antes do início do canal abandonado do rio, a norte antes do início do declive do terreno e a oeste e sul escasseia nas proximidades do brejo Estiva, totalizando uma área de dispersão de $48.319 \mathrm{~m}^{2}$.

A coleta dos vestígios arqueológicos de superfície segundo sua localização espacial no terreno se processou por meio do quadriculamento de toda a área de concentração material identificada pelo caminhamento do terreno. Um total de 224 quadrículas de $10 \times 10 \mathrm{~m}$ cobriu uma área de $160 \times 120 \mathrm{~m}$, na qual todo o material arqueológico foi coletado. Ainda com o objetivo de investigar a configuração do refugo em subsuperfície foram abertas dentro desta malha seis sondagens de $1 \mathrm{~m}^{2}$, a partir das quais foi possível verificar que o pacote arqueológico não ultrapassa $25 \mathrm{~cm}$ de profundidade, sendo os 10 primeiros centímetros os de maior densidade material.

Enquanto o quadriculamento era construído, fora dele duas áreas de concentração material foram selecionadas para a abertura de superfícies amplas de escavação de $2 \times 2$ m, uma posicionada próxima dos alicerces da antiga moradia de alvenaria (área de 
decapagem 1) e outra localizada próxima do brejo Estiva (área de decapagem 2). Contudo, não foi possível captar quaisquer estruturas como fundos de cabana e/ou áreas de lascamento nestas intervenções, cujo registro foi utilizado como referência do comportamento em subsuperfície do refugo arqueológico.

$\mathrm{Na}$ área de decapagem 1, escavada em níveis artificiais de $5 \mathrm{~cm}$, foi evidenciada grande concentração de material cerâmico muito fragmentado até $10 \mathrm{~cm}$ de profundidade, além de uma pequena estrutura de combustão da qual provém a amostra de C14 com a qual este assentamento foi datado em $760 \pm 60$ BP (Beta 184620). Todo o material aí identificado teve sua posição espacial mapeada em croquis de acordo com os níveis escavados. Já na área de decapagem 2 foi identificada uma pequena concentração de material lascado misturado com poucos fragmentos cerâmicos e muitas rochas com marcas de queima sem, contudo, configurar uma estrutura de lascamento.

Próxima de cada área de decapagem foi realizada uma sondagem que atingiu profundidade máxima de $120 \mathrm{~cm}$, a impossibilidade de prosseguir a escavação a partir deste ponto se deu pela presença de latossolo variegado (com formações lateríticas e ferruginosas) muito compactado a partir de $1 \mathrm{~m}$ de profundidade. De maneira geral o solo correspondente à ocupação pré-colonial se caracteriza como areno-argiloso entre solto e ligeiramente compactado com espessura de no máximo $30 \mathrm{~cm}$, fato que propiciou o rebaixamento até $50 \mathrm{~cm}$ de profundidade das demais sondagens abertas no sítio.

O material arqueológico identificado em Estiva 2 possui características relacionáveis a denominada tradição Aratu. Contudo, a presença de material cerâmico Uru nas porções oeste e leste do assentamento indicou que este se encontrava sobreposto ao sítio Estiva 3, suscitando assim questões relativas à interação cultural entre estes grupos, cuja problemática será discutida em detalhe nos capítulos finais desta dissertação. Quanto ao material lítico, caracteriza-se como uma indústria predominantemente sobre lascas e seixos sobre matérias primas em quartzo (na maioria), quartzito e arenito de pouca qualidade.

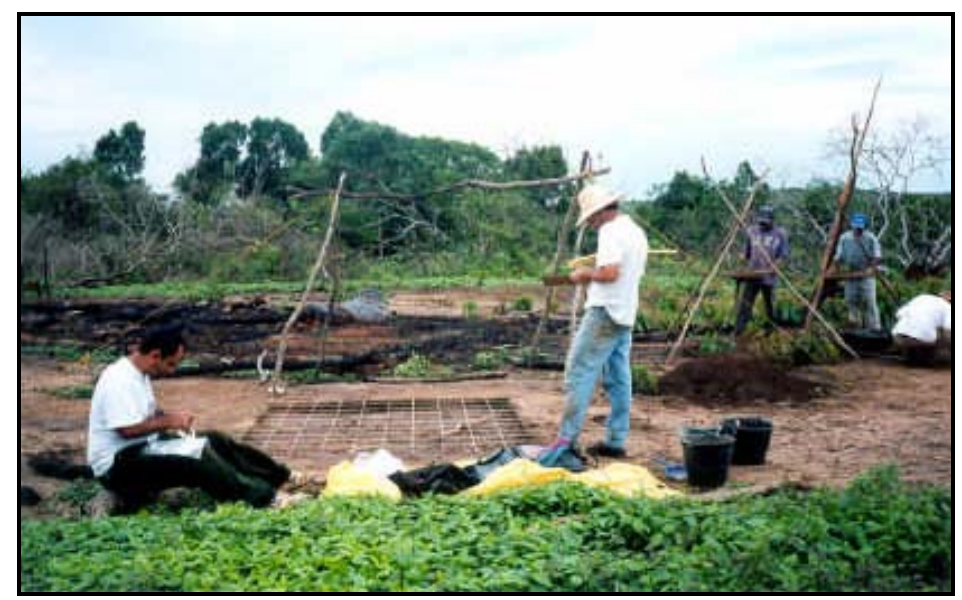

Foto 14: Área de decapagem 1 


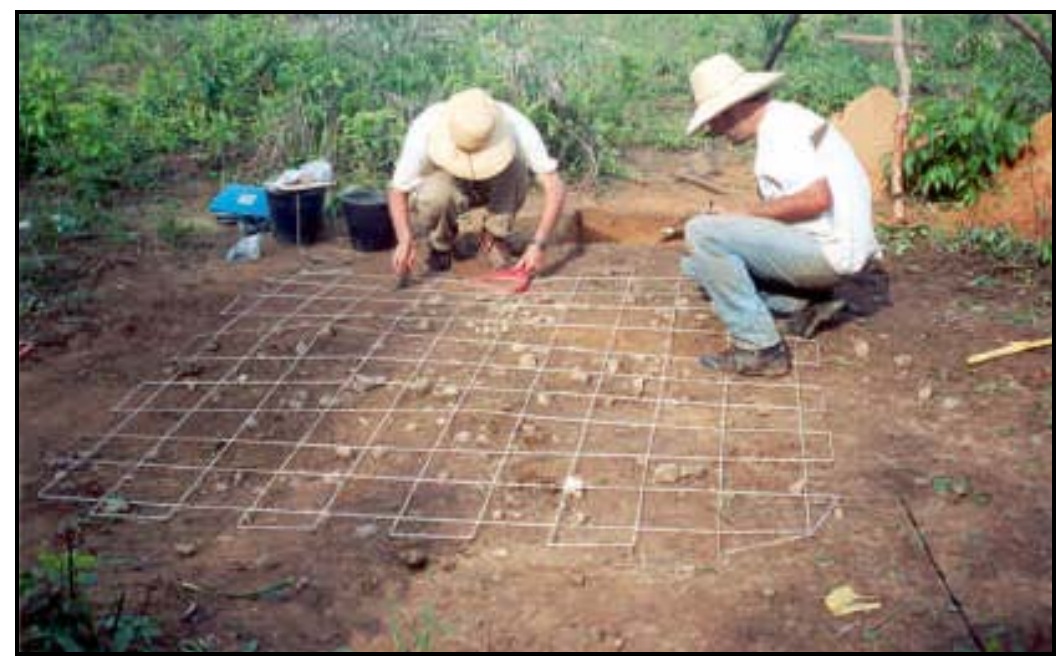

Foto 15: Área de decapagem 2

\subsection{Sítıo Estiva 3 (Ev3)}

Identificado durante a prospecção sistemática na área do sítio Estiva 2, localiza-se em área plana adjacente a este (figura 5). Delimitando a ocorrência material nos setores nordeste-noroeste encontra-se uma drenagem que deságua no brejo Estiva (figura 4), a beira deste curso d'água ruínas de uma residência foram localizadas na porção nordeste, onde se verificou a presença de material cerâmico histórico, bem como lixo doméstico recente. A cobertura vegetal do solo, rasteira e arbustiva apresentou-se mais densa se comparada com a presente em Estiva 2.

O material cerâmico nele identificado possui características relacionáveis à tradição Uru, com fragmentos de coloração cinza, uso do tempero cariapé, bordas reforçadas e bases planas em pedestal remetendo a vasilhames do tipo assador. O material lítico se caracteriza como uma indústria sobre seixos e fragmentos de blocos com matérias primas em quartzo, quartzito e arenito silicificado, entre os artefatos encontram-se choppers, percutores e alguns raspadores.

Num primeiro momento o trabalho de escavação foi direcionado entendendo que esta era uma área periférica do sítio Estiva 2. No entanto, durante a varredura do terreno para identificação da disposição do material em superfície, percebeu-se que se tratava de outro sítio, pois o material encontrado possuía características morfológicas e tecnológicas muito diferentes daquele identificado em Estiva 2, além da dispersão do material ocupar uma área tão grande quanto a do outro sítio. A partir desta constatação o assentamento recém encontrado recebeu o nome de Estiva 3. 

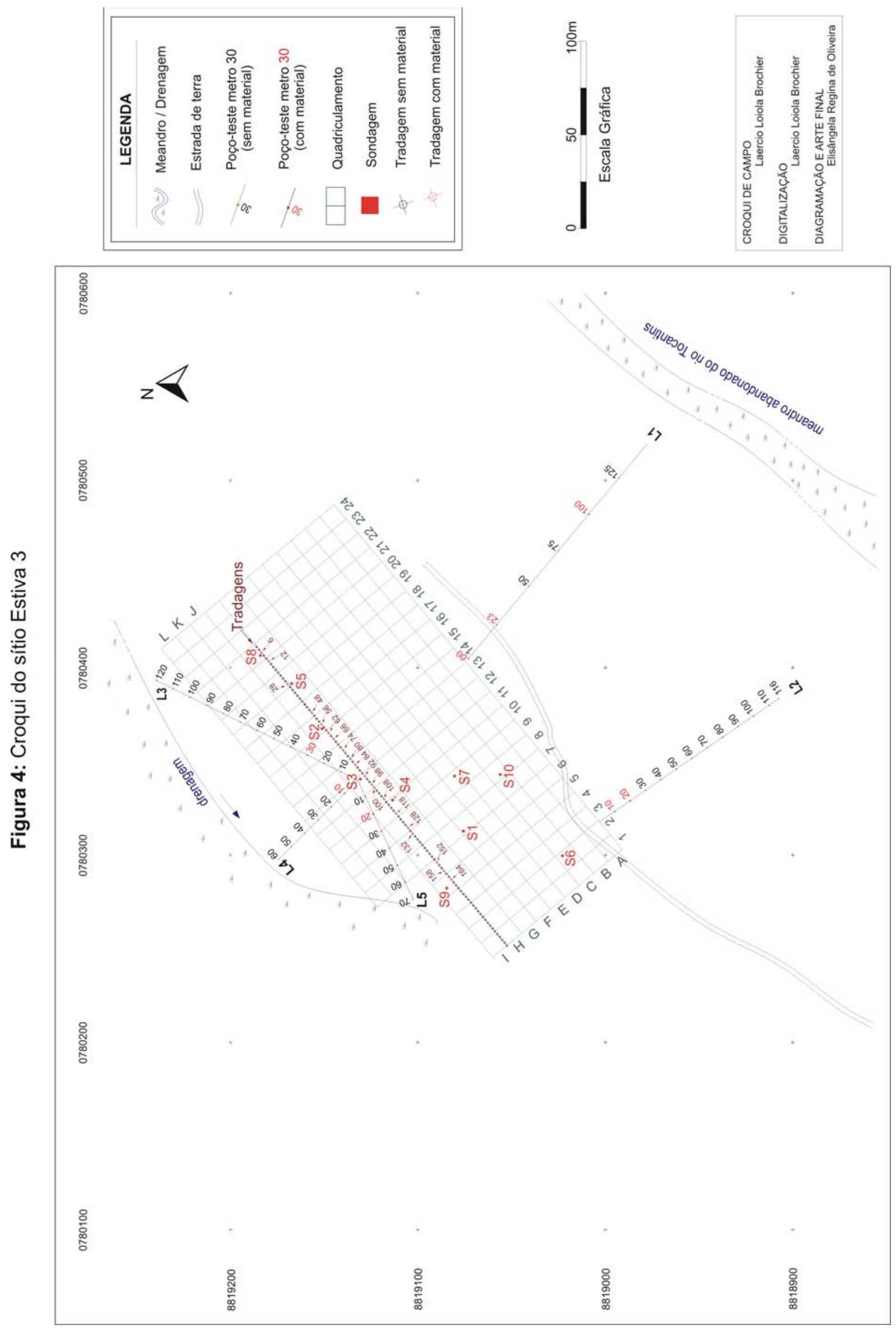


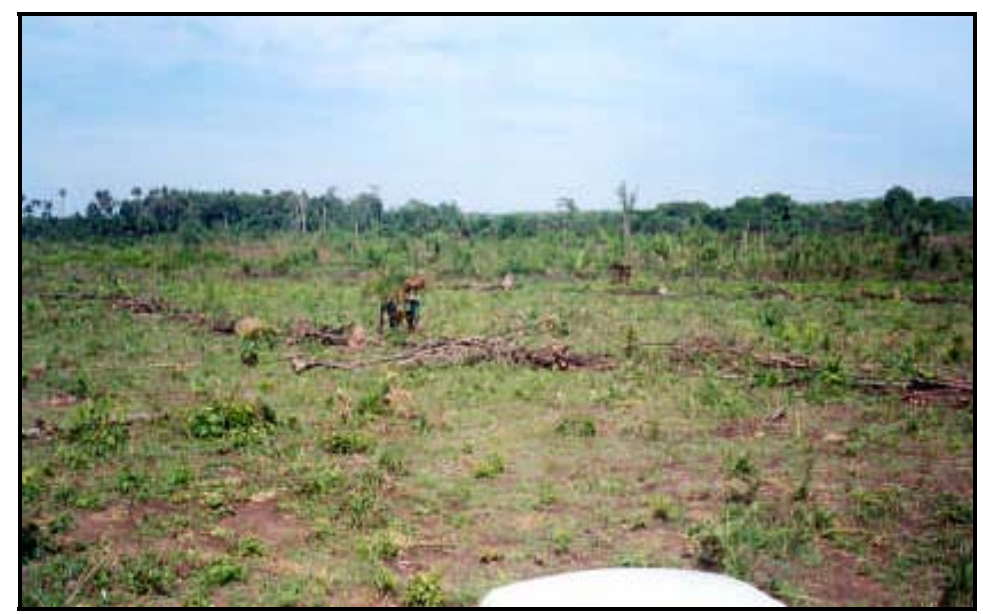

Foto 16: Aspecto geral do terreno no sítio Estiva 3. No centro da foto vê-se uma leira de troncos

Após a identificação visual do material superficial com bandeirinhas azuis, realizada através do caminhamento sistemático no terreno, procedeu-se a construção da malha de 276 quadras de $10 \mathrm{~m}^{2}$ em uma área de $200 \times 90 \mathrm{~m}$, na qual foi realizada a coleta total do material de superfície. A abertura de 10 sondagens $\left(1 \mathrm{~m}^{2} \times 50 \mathrm{~cm}\right.$ de profundidade) e de 5 linhas de poços-teste (dimensões de $0,50 \times 0,50 \mathrm{~cm}$ e $20 \mathrm{~cm}$ de profundidade) para averiguação do comportamento subsuperficial e da área de dispersão do material constituíram as intervenções realizadas neste sítio (figura 4).

Duas linhas de poços-teste (L1 e L2) alcançaram as L2 e L10 localizadas no extremo norte de Estiva 2, enquanto que as L3, L4 e L5 foram abertas na direção da drenagem (figuras 4 e 5). As sondagens não captaram estruturas de combustão preservadas, mas identificaram a superficialidade da camada arqueológica, até $25 \mathrm{~cm}$ de profundidade, portanto o mesmo padrão observado em Estiva 2. Afim de confirmar esta configuração foi aberta uma linha de tradagens no limite das quadras $\mathrm{H}$ e I, que confirmaram de fato este comportamento dos vestígios em subsuperfície.

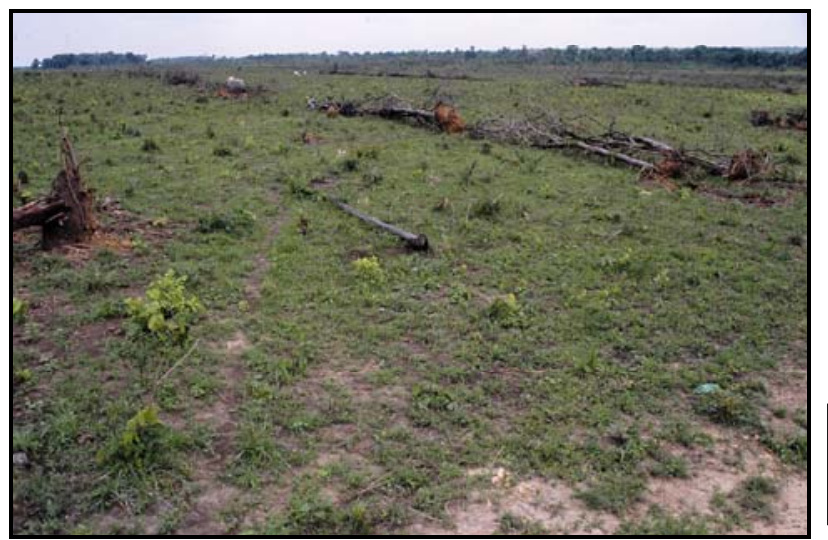

Foto 17: Vista geral da área onde se localiza o sítio Estiva 3 
Estiva 3 foi datado pelo método de termoluminescência ( $T L$ ), pois não foram encontrados quaisquer vestígios de material confiável para a realização de datações por C14. Sua ocupação foi situada em $970 \pm 120$ BP (LVD 1239), portanto anterior à ocupação do sítio Estiva 2, sendo, pois, bastante improvável que seus habitantes tenham se encontrado ou partilhado qualquer tipo de contato direto. Segundo estimativas de Wüst $(1983,1990)$ sítios de até 3 anéis concêntricos não devem ter sido ocupados por mais de duas gerações, o que nos leva a crer que este assentamento, pequeno se comparado a aldeias de 3 anéis concêntricos, não deva ter sido ocupado por mais de uma geração.

De maneira geral Estiva 2 e Estiva 3 são assentamentos de dimensões medianas, cuja morfologia e implantação na paisagem refletem padrões distintos das típicas aldeias circulares que caracterizam a ocupação das respectivas áreas core dos grupos Aratu e Uru. Como será discutido adiante, as características destes sítios demonstram que o médio Tocantins foi ocupado por estes grupos em momento posterior ao início do processo de interação cultural verificado entre eles no restante do Brasil Central. 


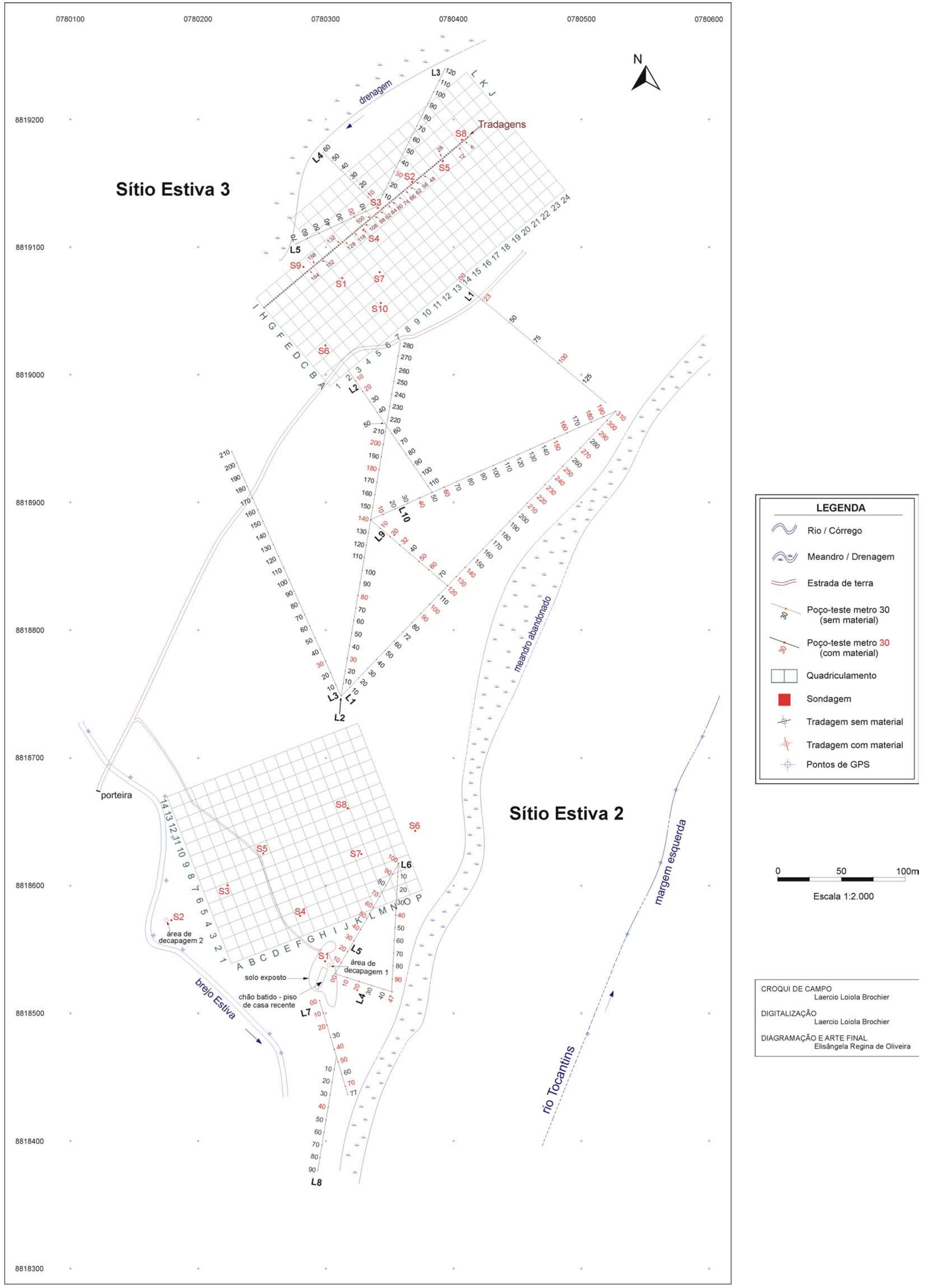




\section{Capítulo V}

AS INDÚSTRIAS CERÂMICAS

\subsection{OBJETIVOS E ORIENTAÇÃo METODOLÓGICA DA ANÁLISE}

$\mathrm{H}$ ipóteses acerca da organização da estrutura do uso do espaço em sítios arqueológicos, estruturadas através do estudo dos padrões do refugo e sua variação ao longo do tempo, tem fornecido parâmetros através dos quais pesquisadores tentam discutir problemáticas mais abrangentes como processos de continuidade e/ou mudança na estrutura das sociedades pretéritas (Allison 1999; Arnold 1990; Carr 1984; Clark 1977; Flannery 1976; Hietala 1984; Hooder \& Orton 1981; Kent 1987; Kroll \& Price 1991; Whallon Jr. 1973, 1974).

As sociedades aqui estudadas, reconhecidas como etnias pertencentes ao grupo lingüístico Jê, aparentemente não desenvolveram sistemas sócio-políticos centralizados tal qual, por exemplo, as sociedades Mesoamericanas e Andinas, todavia, dados etnográficos (Maybury-Lewis 1979; Nimuendajú 1942) e arqueológicos (Wüst 1990) indicam a presença de certo nível de hierarquização interna nestas sociedades. Assim sendo, a compreensão da variabilidade da cultura material no espaço intra-sítio, comparada aos padrões de implantação na paisagem, à morfologia e cronologia dos assentamentos, pode fornecer elementos que possibilitem inferir hipóteses acerca da natureza da organização social destes grupos, bem como de relações que possam ter estabelecido entre si.

Deste modo, uma das maneiras para tentar vislumbrar tal hierarquização seria através do estudo das especificidades destas sociedades no tocante a mecanismos de transformação e manutenção da organização social (Silva 2000; Wüst 2000). Para tanto, com o intuito de identificar elementos indicadores de variação, configurados através de uma distribuição diferenciada de atributos qualitativa e quantitativamente, procedeu-se a análise da cultura material identificada nos sítios arqueológicos pesquisados.

Conforme anteriormente explicitado, as indústrias cerâmicas são o vetor de informação aqui trabalhado. Assim sendo, objetivou-se primeiramente não restringir a 
perspectiva analítica ao universo de fragmentos, mas sim trabalhar com a perspectiva do artefato enquanto unidade básica de análise. Desta forma não o material em si, porém como sua produção está vinculada à cultura e ao ambiente são considerados (Rice 1984).

Portanto, não foram considerados os fragmentos cerâmicos e a análise dos atributos associados de maneira isolada, mas sim a relação que mantêm entre si na forma de vasilhame. Segundo Robrahn-González (1996a: 78-79) esta se mostra uma vantajosa opção quando a proposta recai na identificação de variações dentro de uma mesma indústria, pois é possível o reconhecimento da natureza das alterações, se ocorrem apenas em alguns atributos que passam a ser adotados pela indústria ou se aparecem agrupados em vasilhames, que podem ter sido introduzidos no sítio como artefatos inteiros.

O potencial informativo sobre fenômenos culturais deste artefato é amplo uma vez que além de estar relacionado às funções cotidianas coletivas tais como estocagem e manufatura de alimentos, vincula-se também a usos específicos dentro das sociedades, como atividades ritualísticas e de troca de bens (Robrahn-González 1998). De maneira geral, esta permeabilidade entre contextos sociais distintos, aliada ao alto grau de preservação das peças atesta a relevância do estudo das indústrias cerâmicas na Arqueologia (Barnett \& Hoopes 1995).

Desta forma, pensou-se em uma metodologia de análise capaz de reconhecer as variações tecnológicas próprias de cada uma das indústrias em questão que reflitam opções culturais. Foram realizados estudos qualitativos e quantitativos por meio da análise de atributos morfológicos, tecnológicos e estilísticos de bordas, bases, apêndices, bolotas de argila, rodelas de fuso e demais itens que possibilitassem às análises basearem-se em artefatos, como os vasilhames que podem ser reconstituídos graficamente a partir do desenho dos fragmentos de bordas. A leitura em cada uma destas peças dos atributos selecionados e codificados foi reunida em um banco de dados informatizado, a partir do qual se realizaram testes estatísticos de Cluster e Componente Principal (Cowgill 1968; Johnson \& Wichern 1982).

\subsection{A ANÁLISE DAS INDÚSTRIAS CERÂMICAS DOS SÍTIOS ESTIVA 2 E ESTIVA 3}

Afim de padronizar os termos aqui empregados com aqueles adotados comumente na bibliografia foram consultados manuais de uso corrente na Arqueologia Brasileira como Chmyz 1976, Meggers \& Evans 1970, Rice 1987, Rye 1981 e Shepard 1985. Contudo, em alguns casos foi necessário o estabelecimento de nomenclaturas e critérios de classificação que atendessem a especificidade do material analisado. 
Foram analisados no total 464 fragmentos cerâmicos em ambos os sítios, que se encontram distribuídos nas seguintes classes:

Tabela 1: Quantidade de material analisado por classe nos sítios Estiva 2 e 3

\begin{tabular}{|l|c|l|c|}
\hline \multicolumn{2}{|c|}{ Sítio Estiva 2 } & \multicolumn{2}{c|}{ Sítio Estiva 3 } \\
\hline \multicolumn{1}{|c|}{ Classe } & Quantidade & \multicolumn{1}{c|}{ Classe } & Quantidade \\
\hline Fragmento de borda & 83 & Fragmento de borda & 226 \\
Fragmento de base & 10 & Fragmento de base & 49 \\
Parede decorada & 33 & Parede decorada & 15 \\
Bolota de argila & 10 & Bolota de argila & 23 \\
Trempe & 0 & Trempe & 2 \\
Vaso (borda + base) & 0 & Vaso (borda + base) & 3 \\
Rodela de fuso & 7 & Rodela de fuso & 0 \\
Suporte de tampa & 1 & Suporte de tampa & 0 \\
Borda perfurada & 1 & Borda perfurada & 0 \\
Parede perfurada & 1 & Parede perfurada & 0 \\
\hline Total & $\mathbf{1 4 6}$ & Total & $\mathbf{3 1 8}$ \\
\hline
\end{tabular}

Convém ressaltar que a percentagem de material analisado se refere ao total coletado em superfície na área quadriculada de cada sítio, incluindo-se aí o material proveniente da superfície das sondagens abertas dentro das malhas. Uma vez que as intervenções realizadas em subsuperfície (sondagens, poços-teste e tradagens) tiveram por objetivo a delimitação geral da dispersão material pela área dos sítios por um lado, e por outro a melhor caracterização da região de maior adensamento de vestígios, e sendo que neste último aspecto em ambos os casos confirmaram a tendência observada pela distribuição superficial do material arqueológico, é possível afirmar que o quadriculamento comporta de fato a extensão dos sítios, o que explica a centralização da análise sobre as peças daí provenientes.

No caso do sítio Estiva 2, conforme pode ser observado no croqui do sítio (figura 3), existe uma concentração de material no extremo norte do sítio captada pela abertura das linhas 1, 2, 9 e 10 de poços-teste, tal concentração se refere em grande parte a presença de material lítico, não analisado neste trabalho.

Deste maneira, no sítio Estiva 3 do total de 3.261 peças coletadas em todas as intervenções realizadas, 2.623 são provenientes da coleta quadriculada de superfície. Destas, 339 são peças líticas e 2.284 cerâmicas. Portanto o material analisado (318 peças) 
corresponde a $13,92 \%$ do total de peças cerâmicas coletadas no quadriculamento. Para Estiva 2, do total de 5.354 peças coletadas nas diversas intervenções no sítio, 3.049 correspondem ao material da área quadriculada, deste total 2.150 referem-se a peças cerâmicas e 899 a peças líticas. Assim sendo 6,79\% das peças referentes à coleta quadriculada foram analisadas.

A baixa quantidade de peças analisadas frente à alta densidade do material identificado como um todo advém do fato de em ambos os sítios as peças apresentarem-se muito fragmentadas. A observação da estratigrafia dos assentamentos sugere que o terreno em que se encontram pode ter sido utilizado como roça de toco, pois existiam faixas de sedimento queimado próximo da superfície, além disto, durante a análise material foi observada grande quantidade de fragmentos cerâmicos e líticos que exibiam marcas recentes de fogo em suas superfícies. Também a presença de gado bovino que pastava no terreno indica quais fatores pós-deposicionais influenciaram para a intensa fragmentação do material. No entanto, como já não havia moradores no local quando da escavação dos sítios, não foi possível averiguar a quanto tempo e com que intensidade estes fatores atuaram na área.

Uma vez definido como parâmetro de comparação os trabalhos desenvolvidos no Brasil Central, procurou-se na leitura e classificação dos atributos e suas respectivas variáveis seguir as diretrizes de análise propostas pelos trabalhos de Robrahn-González (1996a) e Wüst (1983, 1990). Além destes trabalhos, para a tipologia das formas dos vasilhames foi consultada a publicação assinada por Schmitz; Wüst; Copé \& Thies (1982), que também serviu de apoio aos trabalhos acima citados uma vez que constitui um dos trabalhos pioneiros de sistematização das indústrias Aratu e Uru do Brasil Central juntamente com Barbosa, Schmitz, Stobäus \& Miranda 1982; Schmitz 1980; Schmitz \& Barbosa 1985; Schmitz, Wüst \& Copé 1981/82.

Desta forma, a análise material considerou um total de 17 atributos relacionados a $\mathbf{8 9}$ variáveis conforme segue:

\section{1 - Espessura da peça}

- de 0,4 a 1,0 cm

- de 1,1 a 2,0 cm

- de 2,1 a 3,0 cm

- de 3,1 a 4,0 cm

- acima de $4,0 \mathrm{~cm}$ 


\section{2 - Antiplástico}

- mineral (grãos de quartzo, feldspato e/ou mica)

- cariapé A

- cariapé $A+B$

- cariapé A + B + caco moído

Durante a secagem e a queima da vasilha cerâmica a argila perde água, o que pode eventualmente ocasionar rachaduras e/ou fissuras nos vasilhames. Para evitar que isto ocorra as oleiras geralmente acrescentam elementos não plásticos à argila afim de fornecer consistência e resistência à pasta cerâmica, tais elementos são denominados de tempero. Contudo, quando não é possível aferir a intencionalidade da presença de materiais antiplásticos na pasta cerâmica, pois tais elementos fazem parte da composição da argila, o termo antiplástico é utilizado (para uma discussão mais detalhada ver Shepard 1985: 24-26).

No Brasil os materiais comumente utilizados como tempero da pasta cerâmica pelos grupos ceramistas pré-coloniais são o cariapé (entrecascas de árvores queimadas e maceradas), o caco moído, resultado da trituração de fragmentos cerâmicos já manufaturados, o cauixi (espículas queimadas e trituradas de esponjas de água doce), conchas moídas e o mineral (grãos de quartzo, feldspato e/ou mica). Nos casos em que a função antiplástica é exercida apenas pelo mineral fica praticamente impossível afirmar se estes elementos foram conscientemente adicionados à pasta ou se fazem parte da composição natural da argila sem um controle analítico, por parte do arqueólogo, acerca das possíveis fontes de argila na região em estudo.

Assim sendo, apesar de nas indústrias aqui analisadas ter sido verificada a presença do tempero cariapé (fotos 17 e 18), optou-se por utilizar de forma genérica o termo antiplástico na denominação deste atributo, pois referente à coleção cuja presença de mineral foi atestada como função antiplástica não foi possível realizar o controle das fontes de matéria-prima disponíveis na área e, por conseguinte, não foi possível confirmar a intencionalidade de seu uso pelos grupos ceramistas em questão. 

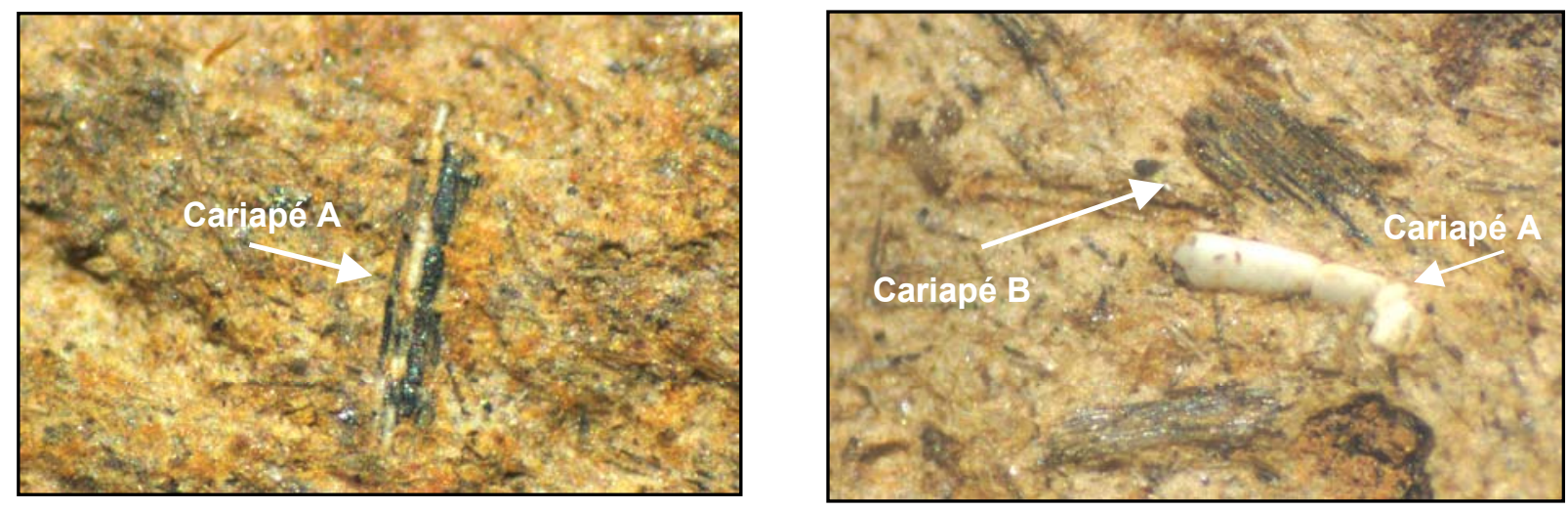

Fotos 18 e 19: Detalhe do tempero cariapé A e B na pasta cerâmica em peças do sítio Estiva 3 (fotos de Wagner Souza e Silva a partir de lupa binocular Zeiss com ampliação de 500 vezes)

\section{3 - Espessura do antiplástico}

- menor que 0,1 cm (pasta fina)

- de 0,1 a 0,3 cm (pasta média)

- de 0,3 a 0,5 cm (pasta grossa)

- acima de $0,5 \mathrm{~cm}$ (pasta muito grossa)

\section{4 - Queima}

- completa (sem núcleo com cor uniforme variando de cinza escuro a pardo)

- completa (sem núcleo, cor uniforme variando de marrom escuro a laranja tijolo)

- incompleta (com núcleo e superfícies int. e ext. variando de cinza claro a pardo)

- incompleta (com núcleo e superfícies interna e externa variando de marrom escuro a laranja tijolo)

\section{5 - Tratamento de superfície}

- alisamento interno / externo

- alisamento interno

- alisamento externo

- não alisado

- perda do alisamento interno

- perda do alisamento externo

- lustro

- polimento interno e externo 


\section{6 - Técnica de manufatura}

- roletado

- modelado

- roletado / modelado

\section{7 - Forma do lábio}

- arredondado

- plano

- plano / redondo (bordas reforçadas)

- plano / afinado (bordas reforçadas)

- biselado

- apontado

- duplo

- afinado

- arredondado aplainado

\section{8 - Distância do lábio ao ponto de inflexão}

- até $1,0 \mathrm{~cm}$

- de 1,1 a $3,0 \mathrm{~cm}$

- de 3,1 a $5,0 \mathrm{~cm}$

- acima de $5,1 \mathrm{~cm}$

\section{9 - Diâmetro da borda}

- 10 a $19 \mathrm{~cm}$

- 20 a $29 \mathrm{~cm}$

- 30 a $39 \mathrm{~cm}$

- 40 a $49 \mathrm{~cm}$

- 50 a $59 \mathrm{~cm}$

- 60 a $69 \mathrm{~cm}$

- 70 a $79 \mathrm{~cm}$

10 - Forma da borda

- direta simples

- direta expandida

- direta reforçada 
- infletida simples

- infletida expandida

- infletida reforçada

- infletida com ponto angular

- introvertida simples

- introvertida reforçada

- cambada

\section{1 - Ângulo de inclinação da borda}

- de $31^{\circ}$ a $60^{\circ}$

- de $61^{\circ}$ a $90^{\circ}$

- de $91^{\circ}$ a $120^{\circ}$

- $121^{\circ}$ a $150^{\circ}$

\section{2 - Formas de vasilhames}

No total foram reconstituídos, seguramente, 103 vasilhames. De acordo com a morfologia destes vasilhames foram identificados 9 diferentes tipos de formas, cuja presença em cada um dos sítios pode ser aferida nas tabelas 2 e 3 .

Tabela 2: Total de reconstituições por forma de vasilhame no Sítio Estiva 2

\begin{tabular}{|c|c|c|c|c|c|c|c|c|c|}
\hline Forma & 1 & 2 & 3 & 4 & 5 & 6 & 7 & 8 & 9 \\
\hline Total & 0 & 2 & 0 & 10 & 1 & 3 & 7 & 0 & 0 \\
\hline
\end{tabular}

Total de reconstituições: 23

Tabela 3: Total de reconstituições por forma de vasilhame no Sítio Estiva 3

\begin{tabular}{|c|c|c|c|c|c|c|c|c|c|}
\hline Forma & 1 & 2 & 3 & 4 & 5 & 6 & 7 & 8 & 9 \\
\hline Total & 2 & 4 & 17 & 7 & 0 & 26 & 4 & 18 & 2 \\
\hline
\end{tabular}

Por não haver peças com inflexões acentuadas (como ombros ou carenas) nas indústrias analisadas, foi considerado apenas o contorno simples nas reconstituições de forma, assim como a presença constante de bases planas e planas em pedestal no sítio Estiva 3 condicionou a representação gráfica simultânea de bases convexas e planas para 
cada forma identificada (pranchas 1 a 4). Deve-se ressaltar, todavia, que a classificação morfológica aqui atribuída aos vasilhames não corresponde necessariamente à classificação funcional definida pelas ceramistas.

\section{Descrição das formas identificadas}

- Forma 1: Prato de contorno direto ou infletido

- Forma 2: Tigela de contorno direto ou infletido (a altura do vaso é menor ou igual à metade do diâmetro da boca)

- Forma 3: Vaso semi-esférico de contorno direto

- Forma 4: Vaso esférico de contorno direto

- Forma 5: Vaso globular de contorno infletido

- Forma 6: Vaso semi-esférico de contorno infletido

- Forma 7: Vaso esférico de contorno infletido

- Forma 8: Vaso cilíndrico de contorno infletido

- Forma 9: Tigela funda de contorno infletido (a altura do vaso é maior que a metade do diâmetro da boca) 


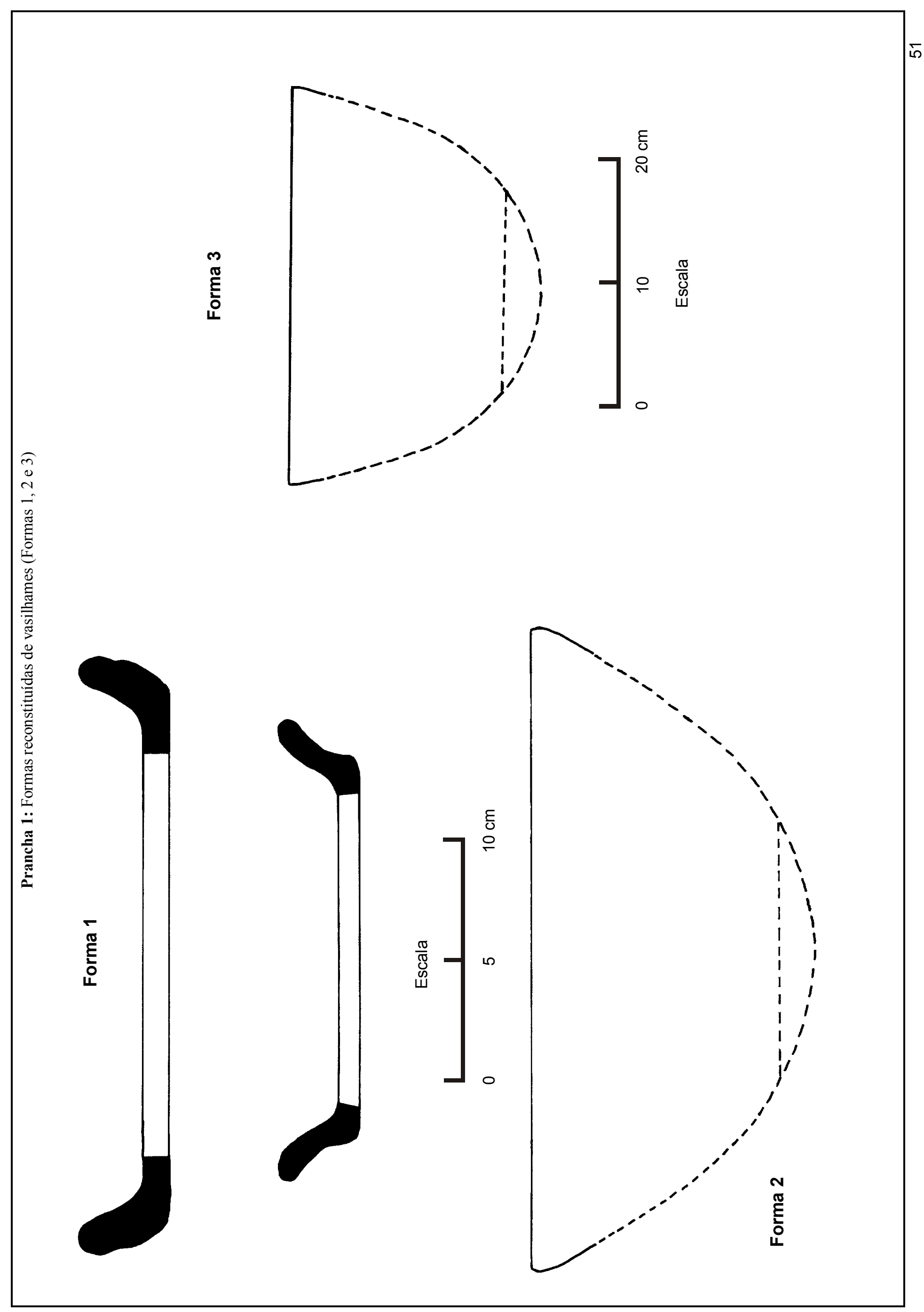




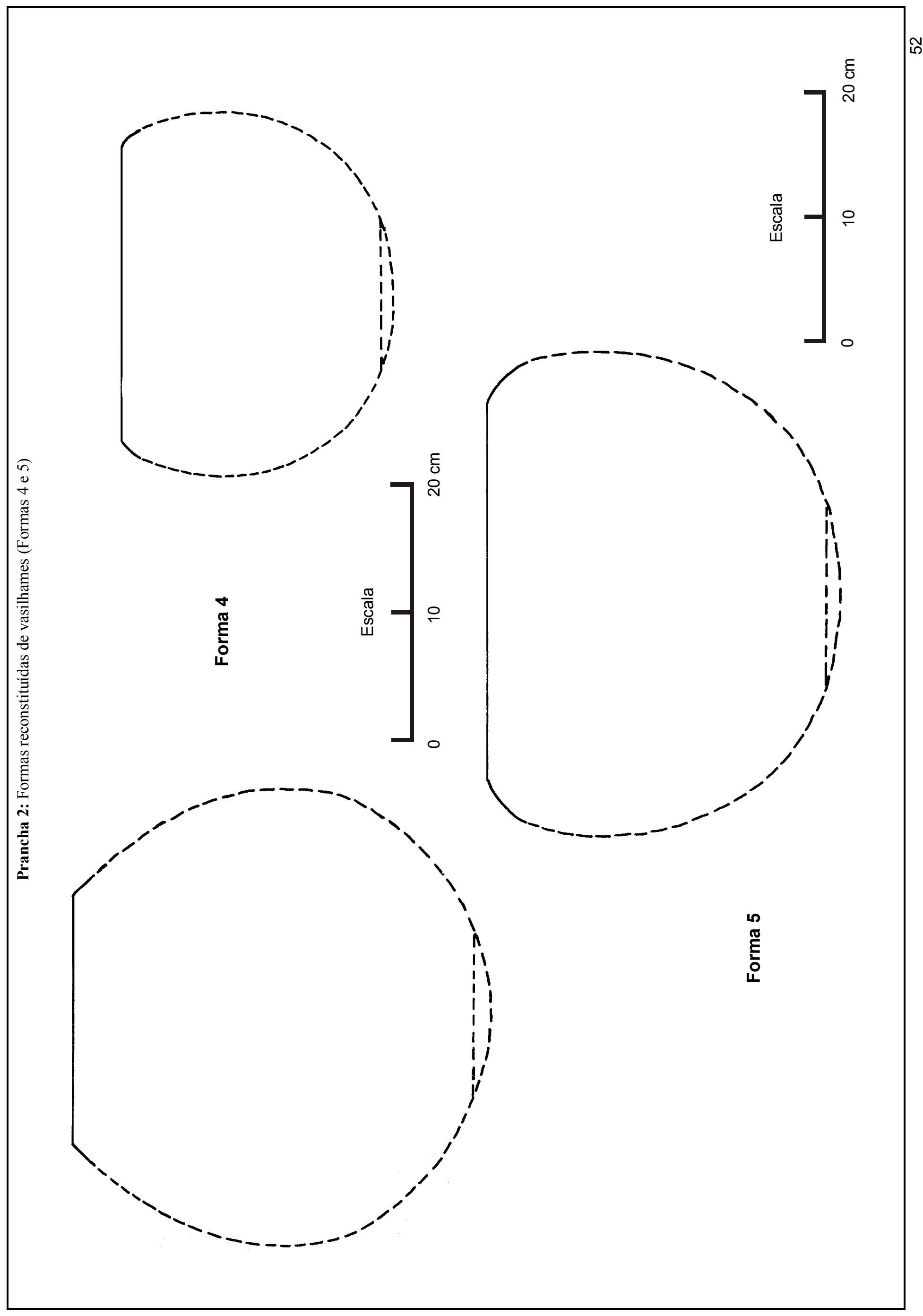




$$
\left[\begin{array}{l}
0 \\
0,4 \\
b 0
\end{array}\right.
$$




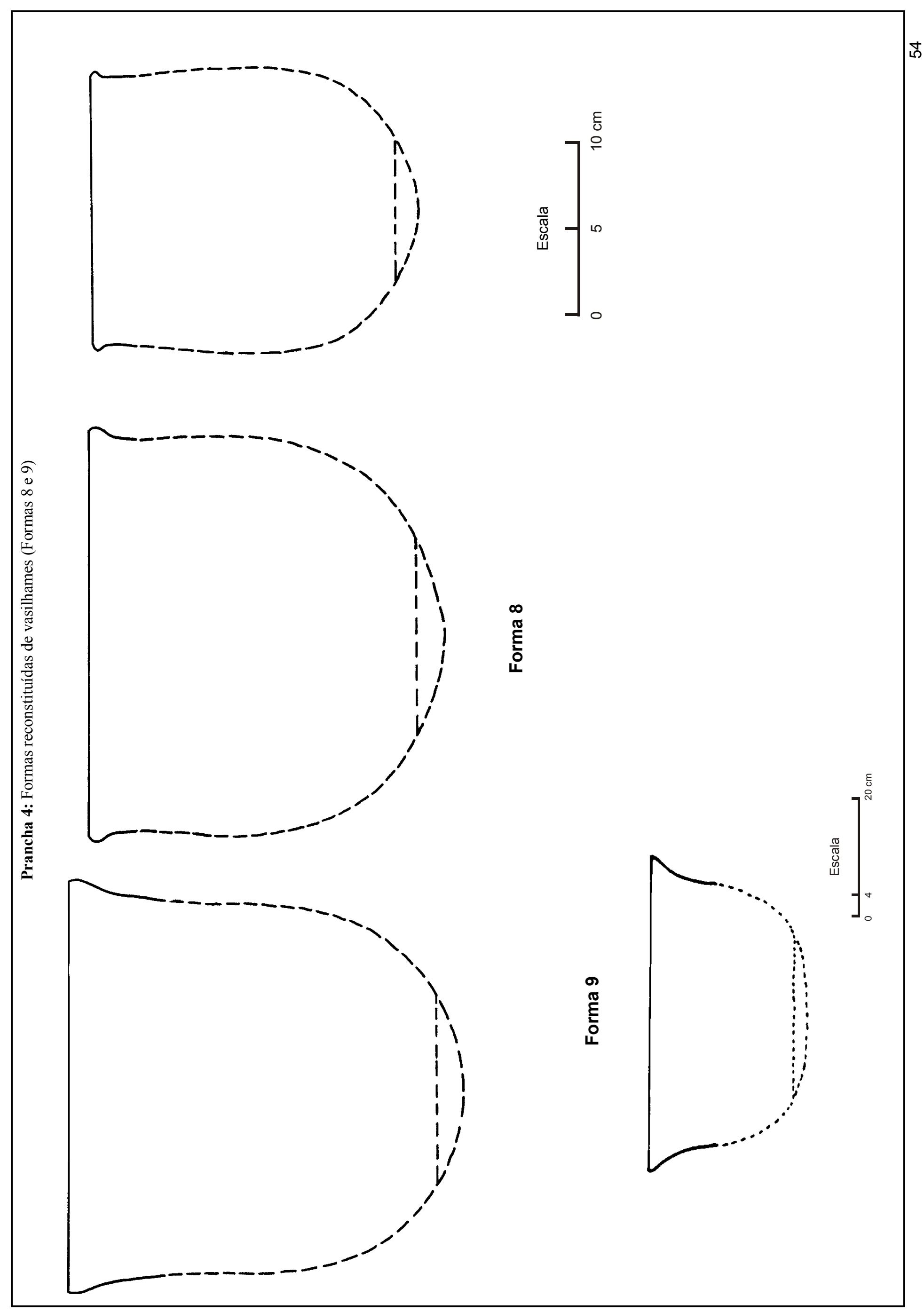




\section{3 - Volume dos vasilhames}

- até 10,0 I

- 10,1 a 30,0 I

- 31,1 a 50,0 I

- acima de 51,0 I

A partir das reconstituições gráficas de forma foi possível calcular aproximadamente o volume em litros que cada um dos 103 vasilhames possuía. Para tanto, utilizou-se a fórmula matemática do cálculo de volume de figuras geométricas relacionadas ao contorno das formas identificadas. Pensando que tais reconstituições representam aproximações gráficas das formas originais dos vasilhames, tal método parece bastante eficaz para a obtenção do volume destes recipientes. Desta forma, para:

- Forma reconstituída de número 1

Figura geométrica: Cilindro

Fórmula: $\pi$ (garganta $\div 2)^{2} \times$ altura $\times 2$

- Formas reconstituídas de números 2, 3 e 9

Figura geométrica: Elipse

Fórmula: $2 / 3 \pi(\text { largura } \div 2)^{2} \times$ altura

- Formas reconstituídas de números 6 e 8

Figura geométrica: Esfera + Cilindro

Fórmula: $4 / 3 \pi$ (largura $\div 2)^{3}+\pi(\text { garganta } \div 2)^{2} \times$ altura $\times 2$

- Formas reconstituídas de números 4, 5 e 7

Figura geométrica: Esfera

Fórmula: $4 / 3 \pi$ (largura $\div 2)^{3}$

\section{4 - Tipo de base}

- plana

- convexa

- côncava

- plana em pedestal 
Prancha 5: Material cerâmico identificado no sítio Estiva 2

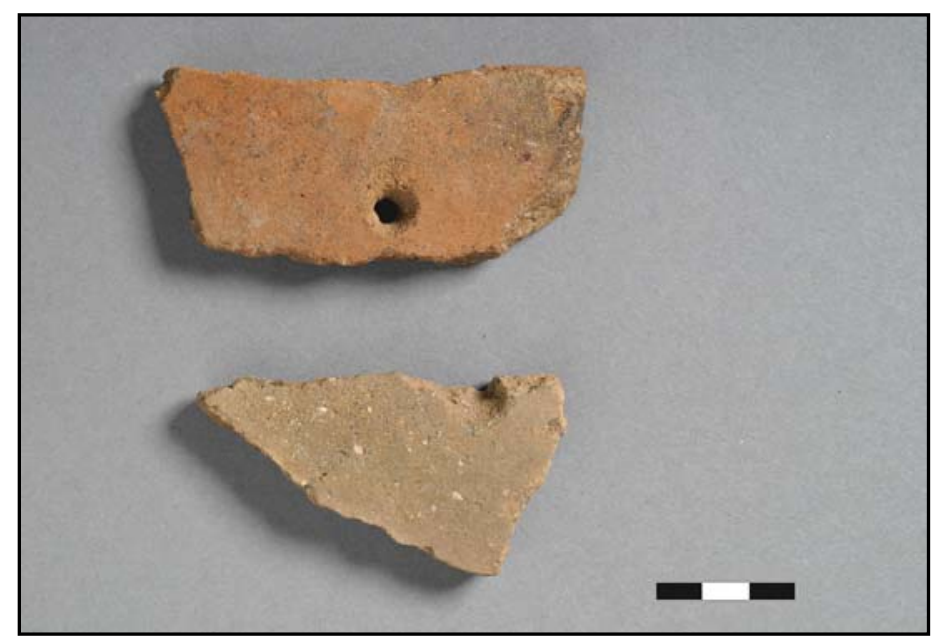

A: Parede (acima) e borda perfurada

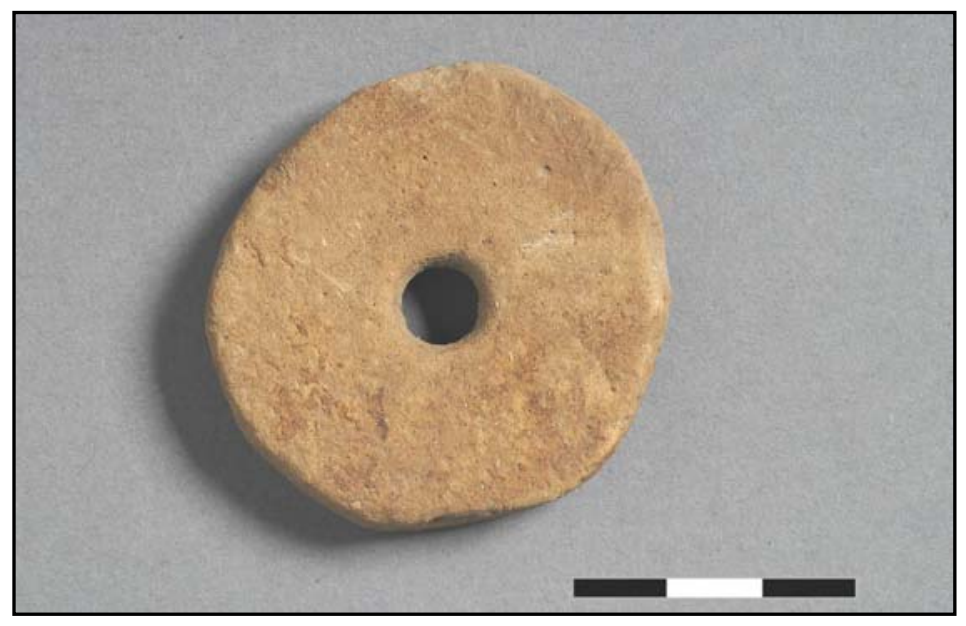

C: Fuso cerâmico com tempero cariapé

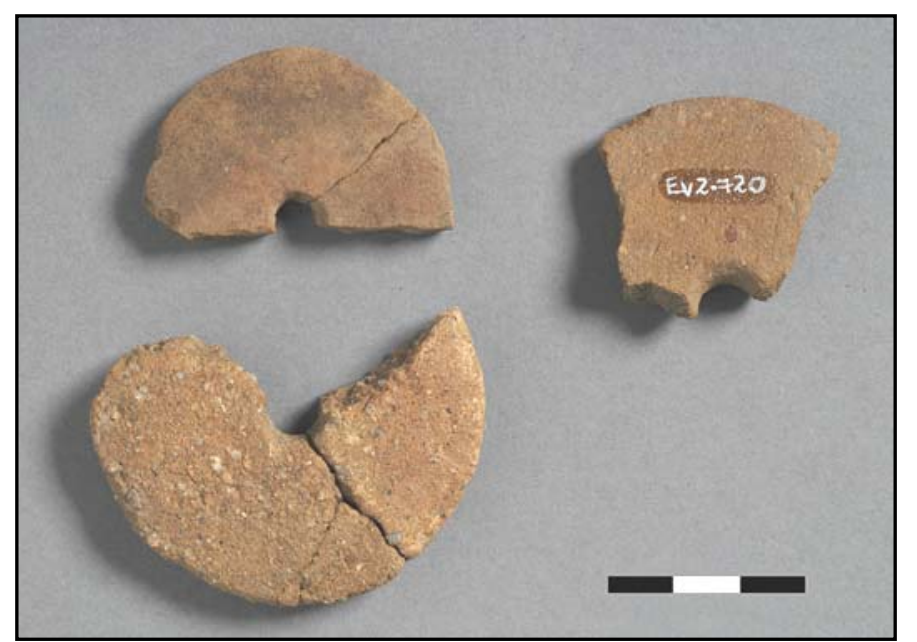

B: Fusos fragmentados

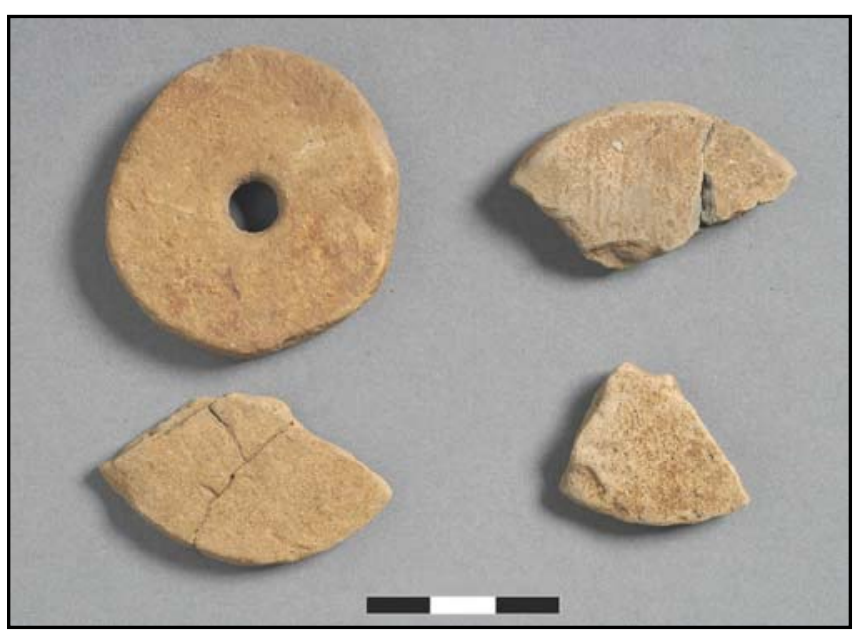

D: Fusos fragmentados (tempero cariapé)

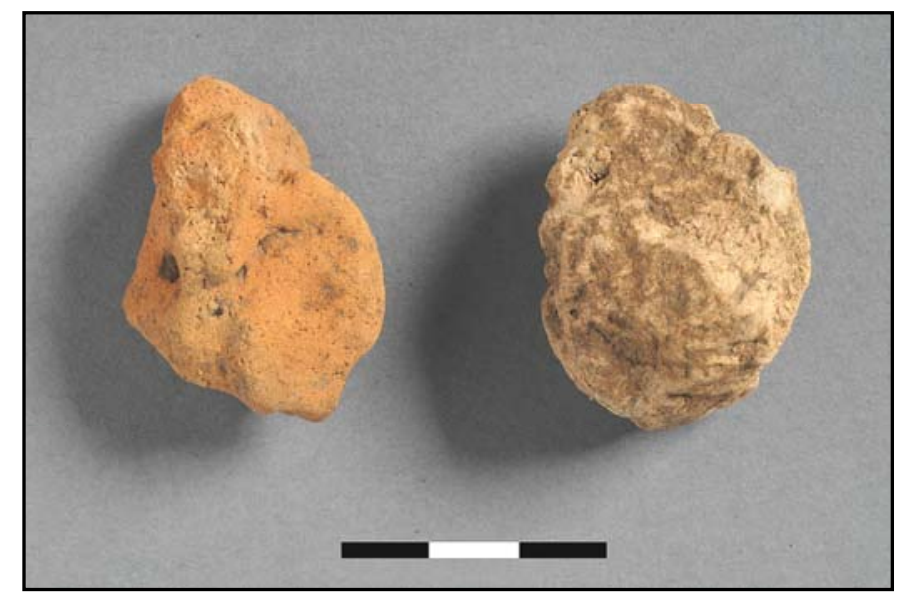

E: Bolotas de argila

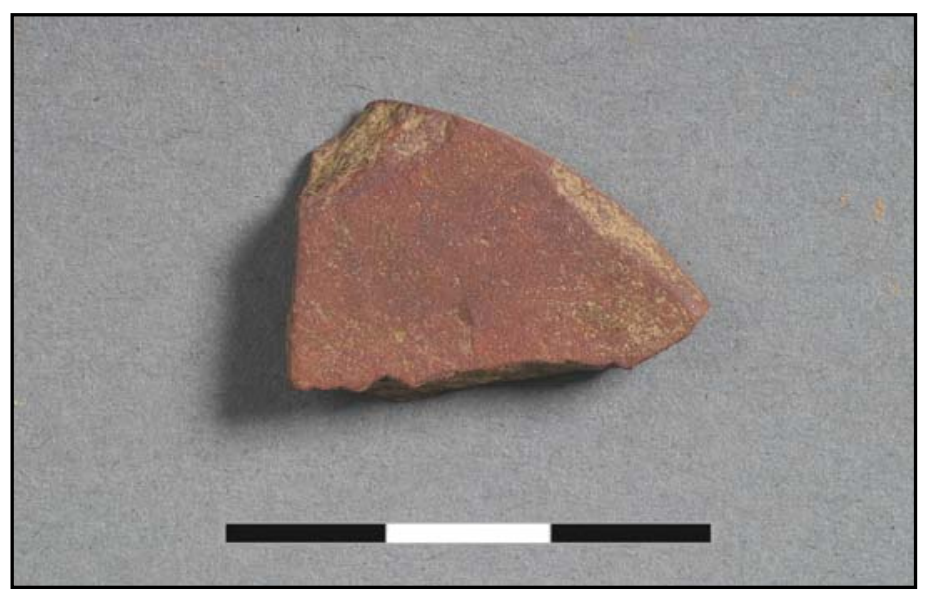

F: Plaqueta de hematita 
Prancha 6: Material cerâmico identificado no sítio Estiva 3

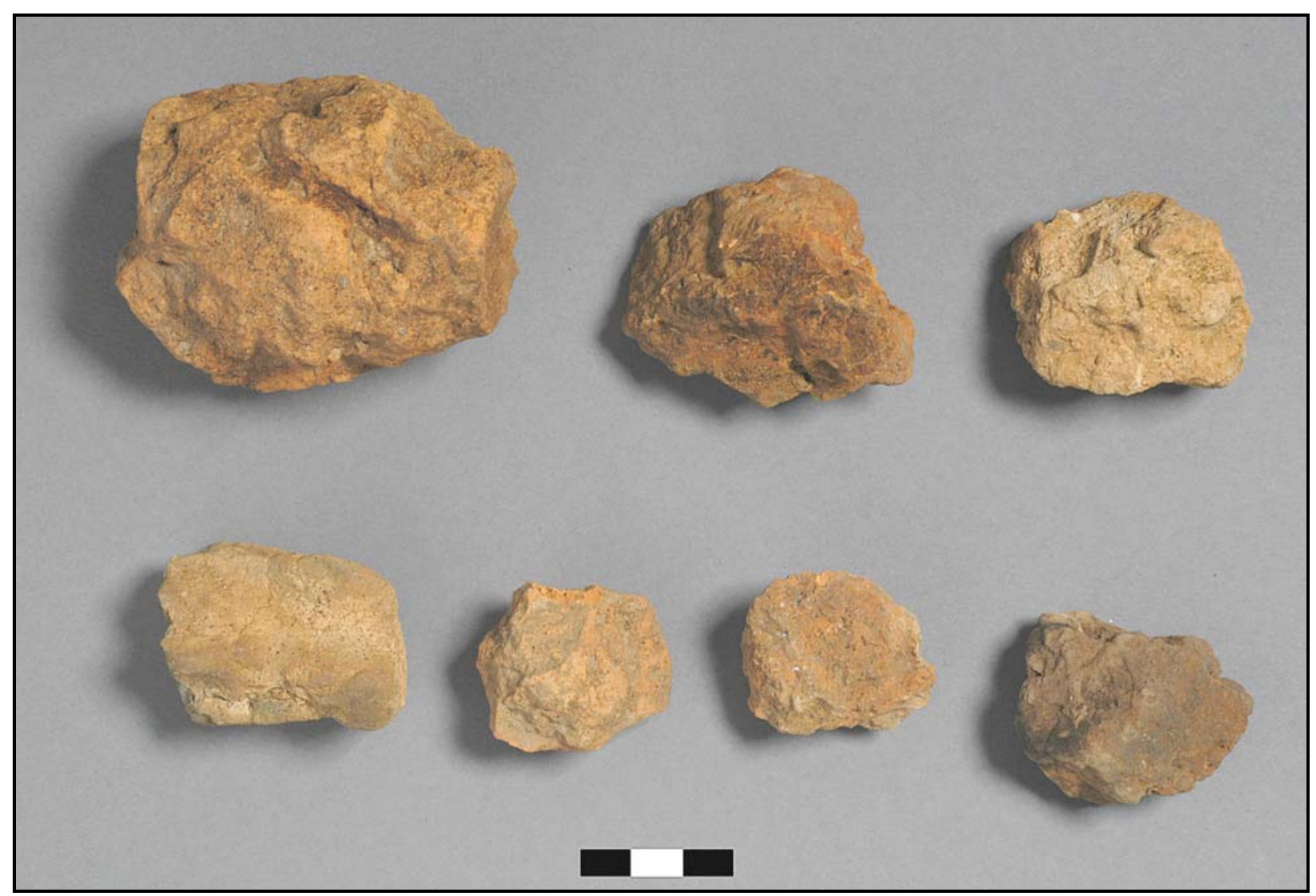

A: Bolotas de argila

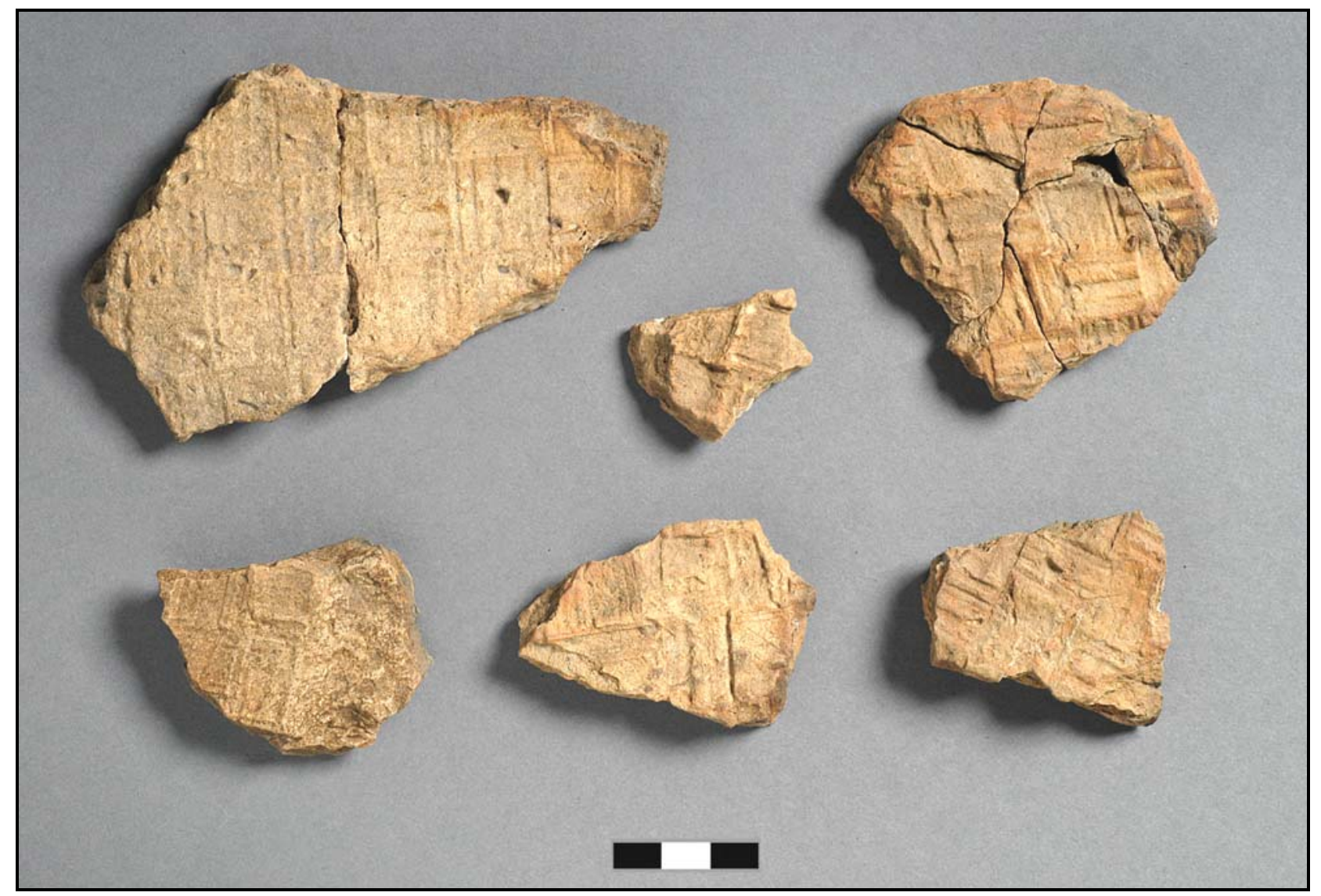

B: Peças com decoração em marca de cestaria 


\section{5 - Diâmetro da base}

- até $10 \mathrm{~cm}$

- de 11 a $20 \mathrm{~cm}$

- de 21 a $25 \mathrm{~cm}$

- acima de $25 \mathrm{~cm}$

\section{6 - Tipo de engobo}

- vermelho externo

- vermelho interno

- vermelho interno / externo

\section{7 - Tipo de decoração}

- marcas de cestaria

- asa (apêndice compacto para suspensão da vasilha)

- canaleta abaixo do lábio

Como anteriormente mencionado, os testes estatísticos a que foram submetidos os dados das análises tecnotipológicas das indústrias cerâmicas dos sítios Estiva 2 e Estiva 3 forneceram, através dos graus de semelhanças presentes entre os artefatos e a partir de um conjunto de atributos, primeiros padrões estilísticos presentes nestas indústrias. No capítulo seguinte serão apresentados de maneira pormenorizada os resultados obtidos nos experimentos estatísticos, sendo aqui explicitadas as características gerais apresentadas pelo conjunto cerâmico de cada um dos sítios em questão.

\subsubsection{Descrição geral da indústria cerâmica de Estiva 2}

As classes de peças diagnósticas analisadas neste sítio foram: fragmentos de borda e base, paredes decoradas (com engobo), bolotas de argila, borda e parede com perfuração, suporte de tampa fragmentado e rodelas de fusos (para a quantificação de cada classe consultar a tabela 1, p. 44).

Das rodelas de fuso encontradas neste sítio, comumente relacionadas às atividades de fiação de fibras como o algodão, metade possuem características morfológicas e tecnológicas relacionadas à tradição Uru, tais como o emprego do antiplástico cariapé e a 
típica coloração cinza claro das superfícies (prancha 5). Analisando a manufatura de tais peças pôde-se identificar um reaproveitamento de artefatos já manufaturados.

A análise dos atributos nas peças diagnósticas indica que, de maneira geral, com relação aos aspectos tecnológicos predomina na indústria as paredes finas (com $58,2 \%$ das peças apresentando espessuras entre 0,4 e $1 \mathrm{~cm})$, o emprego de uma pasta média $(53,4 \%)$ com antiplástico mineral $(97,3 \%)$ e queima incompleta. As bases das vasilhas apresentaram-se entre côncavas e convexas, sendo que das 5 formas de vasilhame identificadas predominam as de número $4(43,48 \%)$ e $7(30,43 \%)$, que constituem vasos esféricos de contorno infletido e direto (pranchas 2 e 3 ).

Independente da forma, os vasilhames deste sítio caracterizam-se como recipientes de grande capacidade, a maioria $(43,48 \%)$ com volume acima de 50 litros, sendo que em diâmetro de boca prevalecem aqueles entre 20 e $29 \mathrm{~cm}$ (47,83\%). Ainda quanto à morfologia das peças, predominam os lábios do tipo arredondado (50,60 \%).

Nenhuma decoração do tipo pintada e/ou plástica foi empregada nos artefatos do sítio Estiva 2, apenas o uso de engobo foi observado em $26 \%$ das peças, sendo que entre estas prevalecem o engobo vermelho aplicado no lado externo da peça e o vermelho aplicado em ambas as superfícies, cada qual demonstrando um percentual de $44,74 \%$ sobre o total de fragmentos com este tipo de técnica.

Considerando as variáveis referentes aos atributos tipo de lábio e diâmetro da borda é possível vislumbrar a baixa integridade dos artefatos desta indústria, uma vez que do total de 83 bordas identificadas apenas $23(27,71 \%)$ possibilitaram a obtenção do diâmetro da vasilha e posterior reconstituição gráfica através do desenho das bordas e $16,87 \%$ do total apresentavam-se tão erodidas que nem ao menos foi possível identificar o tipo de lábio.

Abaixo as tabelas 4 a 13 expõem as quantificações referentes às variáveis identificadas em cada um dos atributos utilizados nas análises estatísticas.

\begin{tabular}{|c|c|c|}
\hline \multicolumn{3}{|c|}{ Tabela 4 - Estiva 2 / Espessura da peça (cm) } \\
\hline & $N^{\circ}$ de peças & $\%$ \\
\hline 0,4 a 1,0 & 85 & 58,2 \\
\hline 1,1 a 2,0 & 56 & 38,4 \\
\hline 2,1 a 3,0 & 4 & 2,7 \\
\hline 3,1 a 4,0 & 1 & 0,7 \\
\hline Total & 146 & 100 \\
\hline
\end{tabular}




\begin{tabular}{|l|c|c|}
\hline \multicolumn{3}{|c|}{ Tabela 5 - Estiva 2 I Antiplástico } \\
\hline & $N^{\circ}$ de peças & $\%$ \\
\hline mineral & 142 & 97,3 \\
\hline cariapé A + B & 4 & 2,7 \\
\hline \multicolumn{1}{|c|}{ Total } & 146 & 100 \\
\hline
\end{tabular}

\begin{tabular}{|l|c|c|}
\hline \multicolumn{3}{|c|}{ Tabela 6 - Estiva 2 / Espessura do antiplástico (cm) } \\
\hline & $N^{\circ}$ de peças & $\%$ \\
\hline menor que 0,1 & 23 & 15,8 \\
\hline 0,1 a 0,3 & 78 & 53,4 \\
\hline 0,3 a 0,5 & 36 & 24,7 \\
\hline acima de 0,5 & 9 & 6,2 \\
\hline \multicolumn{1}{|c|}{ Total } & 146 & 100 \\
\hline
\end{tabular}

\begin{tabular}{|c|c|c|}
\hline \multicolumn{3}{|c|}{ Tabela 7 - Estiva 2 I Queima } \\
\hline & $N^{\circ}$ de peças & $\%$ \\
\hline completa & 15 & 10,3 \\
\hline incompleta & 130 & 89 \\
\hline sem leitura & 1 & 0,7 \\
\hline Total & 146 & 100 \\
\hline
\end{tabular}

\begin{tabular}{|l|c|c|}
\hline \multicolumn{3}{|c|}{ Tabela 8 - Estiva 2 I Tipo de lábio } \\
\hline & $N^{\circ}$ de peças & $\%$ \\
\hline arredondado & 42 & 50,60 \\
\hline plano & 13 & 15,66 \\
\hline biselado & 2 & 2,41 \\
\hline duplo & 1 & 1,21 \\
\hline afinado & 2 & 2,41 \\
\hline arredondado aplainado & 9 & 10,84 \\
\hline sem leitura & 14 & 16,87 \\
\hline \multicolumn{1}{|c|}{ Total } & 83 & 100 \\
\hline
\end{tabular}




\begin{tabular}{|l|c|c|}
\hline \multicolumn{3}{|c|}{ Tabela 9 - Estiva 2 I Formas de vasilhames } \\
\hline & $N^{\circ}$ de peças & $\%$ \\
\hline 2 & 2 & 8,70 \\
\hline 4 & 10 & 43,48 \\
\hline 5 & 1 & 4,35 \\
\hline 6 & 3 & 13,04 \\
\hline 7 & 7 & 30,43 \\
\hline Total & 23 & 100 \\
\hline
\end{tabular}

\begin{tabular}{|l|c|c|}
\hline \multicolumn{3}{|c|}{ Tabela 10 - Estiva 2 / Volume dos vasilhames (litros) } \\
\hline & $N^{\circ}$ de peças & $\%$ \\
\hline até 10,0 & 6 & 21,74 \\
\hline 10,1 a 30,0 & 5 & 26,08 \\
\hline 31,1 a 50,0 & 2 & 8,70 \\
\hline acima de 51,0 & 10 & 43,48 \\
\hline \multicolumn{1}{|c|}{ Total } & 23 & 100 \\
\hline
\end{tabular}

\begin{tabular}{|l|c|c|}
\hline \multicolumn{3}{|c|}{ Tabela 11 - Estiva 2 I Diâmetro da borda (cm) } \\
\hline & $N^{\circ}$ de peças & $\%$ \\
\hline 10 a 19 & 7 & 8,43 \\
\hline 20 a 29 & 11 & 13,25 \\
\hline 30 a 39 & 5 & 6,03 \\
\hline sem leitura & 60 & 72,29 \\
\hline \multicolumn{1}{|c|}{ Total } & 83 & 100 \\
\hline
\end{tabular}

\begin{tabular}{|l|c|c|}
\hline \multicolumn{3}{|c|}{ Tabela 12 - Estiva 2 I Engobo } \\
\hline & $N^{\circ}$ de peças & $\%$ \\
\hline vermelho externo & 17 & 44,74 \\
\hline vermelho interno & 4 & 10,52 \\
\hline vermelho interno / externo & 17 & 44,74 \\
\hline \multicolumn{1}{|c|}{ Total } & 38 & 100 \\
\hline
\end{tabular}




\begin{tabular}{|l|c|c|}
\hline \multicolumn{3}{|c|}{ Tabela 13 - Estiva 2 I Base } \\
\hline & $N^{\circ}$ de peças & $\%$ \\
\hline convexa & 5 & 50 \\
\hline côncava & 4 & 40 \\
\hline sem leitura & 1 & 10 \\
\hline \multicolumn{1}{|c|}{ Total } & 10 & 100 \\
\hline
\end{tabular}

\subsubsection{Descrição geral da indústria cerâmica de Estiva 3}

As classes de peças diagnósticas analisadas neste sítio foram: fragmentos de borda e base, paredes decoradas, bolotas de argila e trempes (para a quantificação de cada classe consultar a tabela 1, p. 44).

A análise dos atributos nas peças diagnósticas indica que, de maneira geral, com relação aos aspectos tecnológicos predomina na indústria a confecção de peças com espessura média (entre 1,1 e 2,0 cm) e pasta cerâmica fina $(49,7 \%)$ com queima predominantemente incompleta $(78,6 \%)$.

$\mathrm{O}$ antiplástico empregado mais comumente combina as variações $\mathrm{A}$ e $\mathrm{B}$ do cariapé, sendo que existem 18 peças com a combinação dos cariapé $A$, B e caco moído $(5,7 \%)$, o que pode indicar algum tipo de contato com grupos filiados à tradição Tupiguarani, estabelecidos a cerca de $1 \mathrm{~km}$ dos sítios aqui pesquisados, em um sítio arqueológico fora da área de inundação da UHE. Existem também 30 peças cujas características tecnológicas e morfológicas remetem ao contexto Aratu, com paredes muito finas e antiplástico mineral.

Quanto à morfologia, os lábios mais frequentemente confeccionados são os do tipo arredondado $(28,38 \%)$, plano $(27,07 \%)$ e plano-redondo $(20,09 \%)$ enquanto que entre as bases prevalecem aquelas planas e convexas.

Entre as formas de vasilhames apenas a de número 5 não se faz presente, sendo predominantes as de número 3, 6 e 8, (vasilhames semi-esféricos de contornos direto e infletido e vasilhames cilíndricos de contorno infletido). Quanto à capacidade volumétrica, independente das formas, a grande maioria dos vasilhames comporta entre 10 a 30 litros.

Com relação aos atributos estilísticos, observa-se uma variabilidade interna, com poucas peças apresentando engobo vermelho (1,3\% do total de peças analisada), decoração em marcas de cestaria $(6,3 \%)$ além do registro de uma peça com aplique em forma de asa. 
Desta forma, verifica-se que enquanto em Estiva 2 impera certa homogeneidade interna no tocante à confecção dos artefatos cerâmicos, em Estiva 3 existe uma diversidade maior quanto aos aspectos morfológicos e estilísticos principalmente.

Abaixo as tabelas 14 a 23 expõem as quantificações referentes às variáveis identificadas em cada um dos atributos utilizados nas análises estatísticas.

\begin{tabular}{|l|c|c|}
\hline \multicolumn{3}{|c|}{ Tabela 14 - Estiva 3 Espessura da peça (cm) } \\
\hline & $N^{\circ}$ de peças & $\%$ \\
\hline 0,4 a 1,0 & 102 & 32,1 \\
\hline 1,1 a 2,0 & 196 & 61,6 \\
\hline 2,1 a 3,0 & 14 & 4,4 \\
\hline 3,1 a 4,0 & 5 & 1,6 \\
\hline acima de 4,1 & 1 & 0,3 \\
\hline \multicolumn{1}{|c|}{ Total } & 318 & 100 \\
\hline
\end{tabular}

\begin{tabular}{|l|c|c|}
\hline \multicolumn{3}{|c|}{ Tabela 15 - Estiva 3 Antiplástico } \\
\hline & $N^{\circ}$ de peças & $\%$ \\
\hline mineral & 30 & 9,4 \\
\hline cariapé A & 5 & 1,6 \\
\hline cariapé A + B & 265 & 83,3 \\
\hline cariapé A + B + caco moído & 18 & 5,7 \\
\hline \multicolumn{1}{|c|}{ Total } & 318 & 100 \\
\hline
\end{tabular}

\begin{tabular}{|l|c|c|}
\hline \multicolumn{3}{|c|}{ Tabela 16 - Estiva 3 / Espessura do antiplástico (cm) } \\
\hline & $N^{\circ}$ de peças & $\%$ \\
\hline menor que 0,1 & 158 & 49,7 \\
\hline 0,1 a 0,3 & 148 & 46,5 \\
\hline 0,3 a 0,5 & 8 & 2,5 \\
\hline acima de 0,5 & 4 & 1,3 \\
\hline \multicolumn{1}{|c|}{ Total } & 318 & 100 \\
\hline
\end{tabular}




\begin{tabular}{|c|c|c|}
\hline \multicolumn{3}{|c|}{ Tabela 17 - Estiva 3 / Queima } \\
\hline & $N^{\circ}$ de peças & $\%$ \\
\hline completa & 49 & 15,4 \\
\hline incompleta & 269 & 84,6 \\
\hline Total & 318 & 100 \\
\hline
\end{tabular}

\begin{tabular}{|l|c|c|}
\hline \multicolumn{3}{|c|}{ Tabela 18 - Estiva 3 / Formas de vasilhames } \\
\hline & $N^{\circ}$ de peças & $\%$ \\
\hline 1 & 2 & 2,5 \\
\hline 2 & 4 & 5 \\
\hline 3 & 17 & 21,25 \\
\hline 4 & 7 & 8,75 \\
\hline 6 & 26 & 32,5 \\
\hline 7 & 4 & 5 \\
\hline 8 & 18 & 22,5 \\
\hline 9 & 2 & 2,5 \\
\hline Total & 80 & 100 \\
\hline
\end{tabular}

\begin{tabular}{|l|c|c|}
\hline \multicolumn{3}{|c|}{ Tabela 19 - Estiva 3 Volume dos vasilhames (litros) } \\
\hline & $N^{\circ}$ de peças & $\%$ \\
\hline até 10,0 & 16 & 20 \\
\hline 10,1 a 30,0 & 33 & 41,25 \\
\hline 31,1 a 50,0 & 17 & 21,25 \\
\hline acima de 51,0 & 14 & 17,5 \\
\hline \multicolumn{1}{|c|}{ Total } & 80 & 100 \\
\hline
\end{tabular}

\begin{tabular}{|c|c|c|}
\hline \multicolumn{3}{|c|}{ Tabela 20 - Estiva 3 / Tipo de lábio } \\
\hline & $N^{\circ}$ de peças & $\%$ \\
\hline arredondado & 65 & 28,38 \\
\hline plano & 62 & 27,07 \\
\hline plano / redondo & 46 & 20,09 \\
\hline plano / afinado & 3 & 1,31 \\
\hline biselado & 11 & 4,80 \\
\hline apontado & 2 & 0,88 \\
\hline duplo & 7 & 3,06 \\
\hline sem leitura & 33 & 14,41 \\
\hline Total & 229 & 100 \\
\hline
\end{tabular}




\begin{tabular}{|l|c|c|}
\hline \multicolumn{3}{|c|}{ Tabela 21 - Estiva 3 / Diâmetro da borda (cm) } \\
\hline & $N^{\circ}$ de peças & $\%$ \\
\hline 10 a 19 & 6 & 2,62 \\
\hline 20 a 29 & 36 & 15,72 \\
\hline 30 a 39 & 24 & 10,48 \\
\hline 40 a 49 & 14 & 6,11 \\
\hline 50 a 59 & 14 & 6,11 \\
\hline 60 a 69 & 2 & 0,88 \\
\hline 70 a 79 & 1 & 0,44 \\
\hline sem leitura & 132 & 57,64 \\
\hline Total & 229 & 100 \\
\hline
\end{tabular}

\begin{tabular}{|c|c|c|}
\hline \multicolumn{3}{|c|}{ Tabela 22 - Estiva 3 / Base } \\
\hline & $\overline{N^{\circ} \text { de peças }}$ & $\%$ \\
\hline plana & 17 & 32,69 \\
\hline convexa & 10 & 19,23 \\
\hline côncava & 2 & 3,85 \\
\hline plana com pedestal & 9 & 17,31 \\
\hline sem leitura & 14 & 26,92 \\
\hline Total & 52 & 100 \\
\hline
\end{tabular}

\begin{tabular}{|l|c|c|}
\hline \multicolumn{3}{|c|}{ Tabela 23 - Estiva 3 / Decoração } \\
\hline & $N^{\circ}$ de peças & $\%$ \\
\hline marcas de cestaria & 15 & 75 \\
\hline asa & 2 & 10 \\
\hline canaleta abaixo do lábio & 3 & 15 \\
\hline \multicolumn{1}{|c|}{ Total } & 20 & 100 \\
\hline
\end{tabular}




\section{Capítulo VI}

ANÁLISES ESTATÍSTICAS

\subsection{APRESENTAÇÃO E DISCUSSÃO DOS DADOS}

$\mathrm{P}$

ara o desenvolvimento dos testes estatísticos foram comparados de forma simultânea 12 dos 17 atributos analisados e as variáveis a eles relacionadas por meio da Análise de Cluster (distância euclidiana e método de ligação completa) e de Componentes Principais. Todo o tratamento estatístico foi realizado pela Empresa Júnior de Informática, Matemática e Estatística do Instituto de Matemática e Estatística da Universidade de São Paulo (IME Jr.).

As variáveis forma da borda e distância do lábio ao ponto de inflexão foram excluídas do tratamento estatístico por se sobreporem às variáveis ângulo de inclinação da borda e forma do vasilhame, estes dois mantidos nos testes. Também não participaram das análises estatísticas os atributos diâmetro da base, técnica de manufatura e tratamento de superfície devido em parte ao tamanho da matriz a ser analisada (caso do diâmetro da base) e em razão da grande homogeneidade com que se apresentaram.

Na seqüência são expostos separadamente os resultados do tratamento estatístico dos dados levantados em cada sítio, após o que segue uma tentativa de interpretação de padrões detectados nos assentamentos, bem como possíveis relações entre si. Tais considerações serão retomadas nas considerações finais, de modo a subsidiar as hipóteses aqui levantadas.

A distribuição dos artefatos cerâmicos em superfície indica para o sítio Estiva 2 uma morfologia circular de contorno irregular, sendo que as curvas de nível de sua densidade evidenciaram 13 concentrações de material com grande espaçamento entre si (figuras 6 e 7).

Ambos os testes de Cluster e Componente Principal apresentaram resultados essencialmente semelhantes, indicando que as variáveis que apresentam maior porcentagem de contribuição para a distinção de conjuntos na indústria do sítio são: espessura da peça $(0,4$ a 1,0 cm; 1,1 a 2,0 cm; 2,1 a 3,0 cm e 3,1 a 4,0 cm), espessura do 
Figura 6 - Sítio Estiva 2

Mapa de densidade do material cerâmico

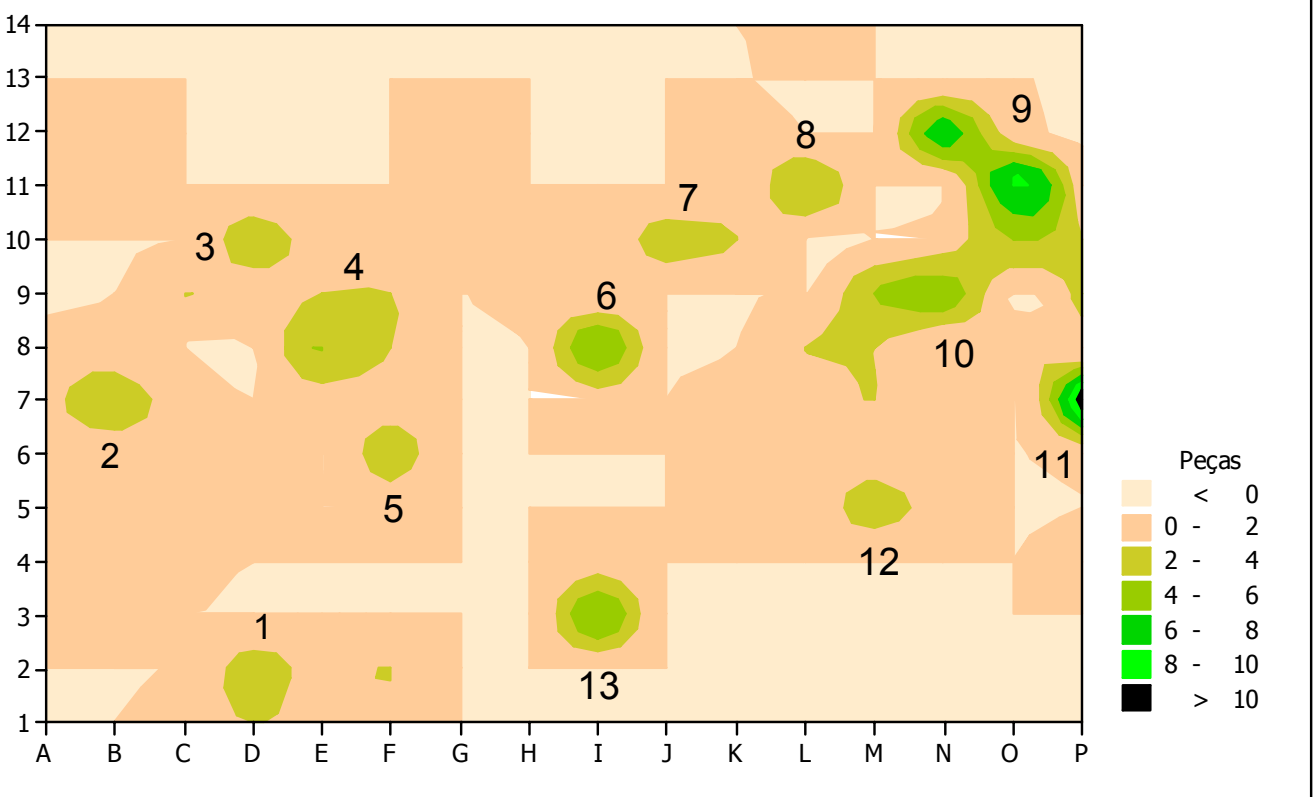

Figura 7 - Sítio Estiva 2

Densidade dos artefatos cerâmicos

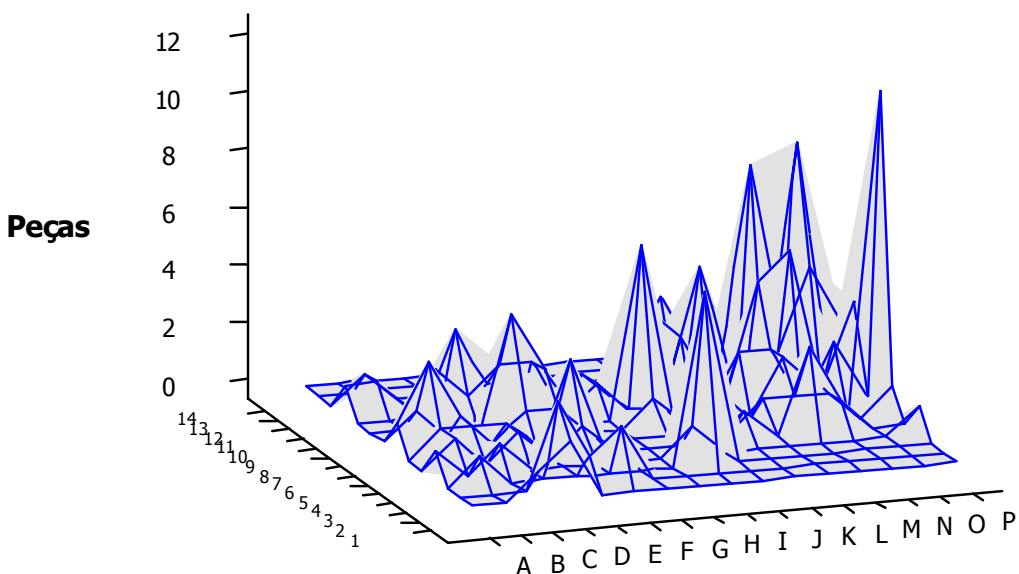


antiplástico (menor que $0,1 \mathrm{~cm} ; 0,1$ a $0,3 \mathrm{~cm} ; 0,3$ a $0,5 \mathrm{~cm}$ e acima de $0,5 \mathrm{~cm}$ ), queima (completa e incompleta) e tipo de engobo (vermelho externo; vermelho interno e vermelho interno / externo).

Segundo a análise de Componente Principal na primeira componente, a de maior representatividade, as variáveis mais relacionadas são espessura do antiplástico, queima e engobo sendo inversa a participação da variável espessura da peça. Na segunda componente as variáveis mais relacionadas são espessura da peça, espessura do antiplástico e tipo de engobo (as duas últimas com menor participação) sendo inversa a participação da variável queima (tabela 24 e anexo 1).

Tabela 24: Resultado da análise de componente principal (sítio Ev2)

\begin{tabular}{|lrr|}
\hline Variable & PC1 & PC2 \\
\hline ESP PÇ & $-0,224$ & $\mathbf{0 , 8 2 0}$ \\
\hline ESP ANTI & $\mathbf{0 , 5 8 2}$ & $\mathbf{0 , 3 8 6}$ \\
\hline QUEIMA & $\mathbf{0 , 6 2 4}$ & $-0,294$ \\
\hline CDENG & $\mathbf{0 , 4 7 0}$ & $\mathbf{0 , 3 0 3}$ \\
\hline
\end{tabular}

Os testes identificaram a presença de quatro conjuntos ou grupos artefatuais no sítio Estiva 2 (vide dendograma de Cluster no anexo 1). Afim de caracterizar cada um destes grupos será agora apresentada a análise das indústrias cerâmicas a partir da classificação morfológica dos vasilhames reconstituídos, tidos aqui como unidade básica de análise, para daí ponderar sobre a ocorrência dos demais atributos segundo as variáveis que contribuíram diretamente para a formação destes conjuntos. Desta forma, se em determinado conjunto registra-se a forma tigela, serão descritos os tipos de antiplástico, queima, volume que apresenta e assim sucessivamente para cada uma das formas identificadas.

\section{Grupo 1}

Composto por um total de 65 peças cujas principais características são: espessura da parede até $1 \mathrm{~cm}$, pasta média $(0,1$ a $0,3 \mathrm{~cm})$, queima incompleta e ausência de engobo.

As formas a ele relacionadas são as de número 2 com volumes até 10 litros, 4 (de todos os tamanhos, desde os vasilhames com capacidade até 10 litros indo aos extragrandes com mais de 50 litros de volume), 6 (com até 10 litros de volume) e 7 (vasilhas com volumes entre 10 e 30 litros, bem como acima de 50 litros).

Também fazem parte deste grupo rodelas de fuso, bolotas de argila e a borda com perfuração. 


\section{Grupo 2}

Este grupo reúne um total de 18 peças assim caracterizadas: espessura da parede entre 1,1 e 2,0 cm, pasta fina e queima completa com cor uniforme variando de marrom escuro a laranja tijolo.

O único vasilhame presente neste grupo possui forma 7 e volume acima de 51 litros. Estão reunidas aí a maioria das bolotas de argila, a parede perfurada e grande parte dos fusos identificados no sítio.

\section{Grupo 3}

O grupo 3 reúne 42 peças, cujas características principais são a espessura de parede fina (menor que $0,1 \mathrm{~cm}$ ), a pasta grossa com queima incompleta e a presença de peças com engobo vermelho externo.

As formas a ele relacionadas são as de número 2 com volume até 10 litros, 4 com capacidade acima de 50 litros, 5 de volume até 10 e a forma 7 com capacidade superior a 501.

Este grupo comporta também a grande maioria das peças com engobo vermelho e agrega rodelas de fuso.

\section{Grupo 4}

21 peças formam este conjunto, caracterizadas pelas paredes de espessura predominantemente fina, pasta variando entre média e grossa e queima incompleta apresentando cor uniforme variando de marrom escuro a laranja tijolo, além das peças com engobo em ambas as superfícies.

A única forma relacionada ao grupo foi a de número 4 , com capacidade acima de 50 litros.

Pode-se observar tanto pelas descrições quanto pela análise do dendograma que o grupo 2 é o que mais se distancia dos demais, ao mesmo tempo em que os grupos mais próximos (semelhantes) são os de número 3 e 1. Aliás, são estes conjuntos que agregam maior diversidade qualitativa de formas e volumes de vasilhames no sítio. 
Para o sítio Estiva 3 a distribuição dos artefatos cerâmicos em superfície indica um assentamento com morfologia circular de contorno irregular no qual se encontram 11 concentrações de material que, diferentemente de Estiva 2, encontram-se próximas entre si (figuras 8 e 9).

Também neste sítio os resultados dos testes de Cluster e Componente Principal foram essencialmente semelhantes, indicando que as variáveis que apresentam maior porcentagem de contribuição para a distinção de conjuntos são: espessura da peça $(0,4$ a $1,0 \mathrm{~cm} ; 1,1$ a $2,0 \mathrm{~cm} ; 2,1$ a $3,0 \mathrm{~cm} ; 3,1$ a $4,0 \mathrm{~cm}$ e acima de $4,1 \mathrm{~cm}$ ), antiplástico (mineral; cariapé $A$; cariapé $A+B$ e cariapé $A+B+$ caco moído), espessura do antiplástico (menor que $0,1 \mathrm{~cm} ; 0,1$ a $0,3 \mathrm{~cm} ; 0,3$ a $0,5 \mathrm{~cm}$ e acima de $0,5 \mathrm{~cm}$ ) e queima (completa e incompleta).

Segundo a análise de Componente Principal a primeira componente, a de maior representatividade, é formada pela participação igual das variáveis espessura da peça e antiplástico, porém esta última atua de forma inversa, também tem participação inversa em relação à espessura do antiplástico as variáveis queima e espessura do antiplástico. $\mathrm{Na}$ segunda componente a variável mais relacionada é a espessura do antiplástico, com a variável antiplástico com participação inversa (tabela 25 e anexo 2).

Tabela 25: Resultado da análise de componente principal (sítio Ev3)

\begin{tabular}{|lrr|}
\hline Variable & PC1 & PC2 \\
\hline ESP PÇ & $\mathbf{0 , 6 7 6}$ & 0,261 \\
\hline ANTIPLÁS & $-0,662$ & $-0,062$ \\
\hline ESP ANTI & $-0,088$ & $\mathbf{0 , 8 4 8}$ \\
\hline QUEIMA & $-0,311$ & 0,458 \\
\hline
\end{tabular}

Os testes também identificaram a presença de quatro conjuntos ou grupos artefatuais no sítio Estiva 3 (vide dendograma de Cluster no anexo 2). Assim sendo, tal qual realizado acima, cada grupo será caracterizado a partir da indústria a eles relacionada.

\section{Grupo 1}

166 peças formam este grupo, caracterizado pelas seguintes variáveis: espessura da peça entre 1,1 e 2,0 cm, espessura do antiplástico entre 0,1 e 0,3 cm, queima variando entre completa e incompleta e antiplástico cariapé $A+B$.

As formas de vasilhame relacionadas são: 1 (prato assador com menos de 10 litros de volume), 2 (os vasilhames possuem capacidade até $10 \mathrm{l}$ e entre 10 e 30l), 3 (vasilhames com capacidades diversas, desde menos de 10l até acima de 50), 4 (esta forma apresenta 
volumes entre 10 e até 50l), 6 (vasilhas de diversos tamanhos, dos pequenos até os extragrandes), 7 (vasilhames predominantemente grandes, entre 30 e 50 litros), 8 (variação de volumes, desde 10 até 30 litros) e forma 9 (com volume entre 30 e 50 litros).

Além de agregar grande variabilidade de formas e volumes de vasilhames, este grupo ainda comporta as peças com decoração em marca e cestaria e engobo vermelho externo.

\section{Grupo 2}

O grupo 2 possui um total de 26 peças cujas características são: paredes com espessura variando entre 2,1 e 3,0 cm, pasta entre fina e média, antiplástico mineral e cariapé A e queima completa e incompleta. Nenhum vasilhame aparece neste conjunto, em contrapartida, todas as bolotas de argila e trempes identificadas encontram-se aqui agregados.

\section{Grupo 3}

Este grupo concentrou as peças com características relacionadas à tradição Aratu. São 9 peças assim descritas: queima incompleta, antiplástico mineral, pasta média e espessuras de parede pequenas, de até $1,0 \mathrm{~cm}$.

A única forma a ele agregada foi a de número 4, apresentando volume entre 10 e 30 litros.

\section{Grupo 4}

Grupo formado por 17 peças cujos atributos diferenciadores são: antiplástico cariapé combinado com caco moído, queima incompleta e completa, espessura do antiplástico mediana e paredes com espessura entre 1,1 e 2,0 cm.

As formas relacionadas são: 3 (capacidade entre 10 e 30 litros), 4 representada por uma peça de grande capacidade (mais de 50I) e $\mathbf{8}$ (volumes com menos de 10 litros e entre 10 e 30 litros).

O grupo 1 possui nitidamente a maior diversidade qualitativa se analisarmos a presença em seu agrupamento do maior número de tipos de forma e volume de vasilhames, da mesma forma que neste grupo também estão presentes bolotas de argila, pintura de engobo vermelho e fusos, artefatos presentes também em todos os demais grupos. Desta 
Figura 8 - Sítio Estiva 3

Mapa de densidade do material cerâmico

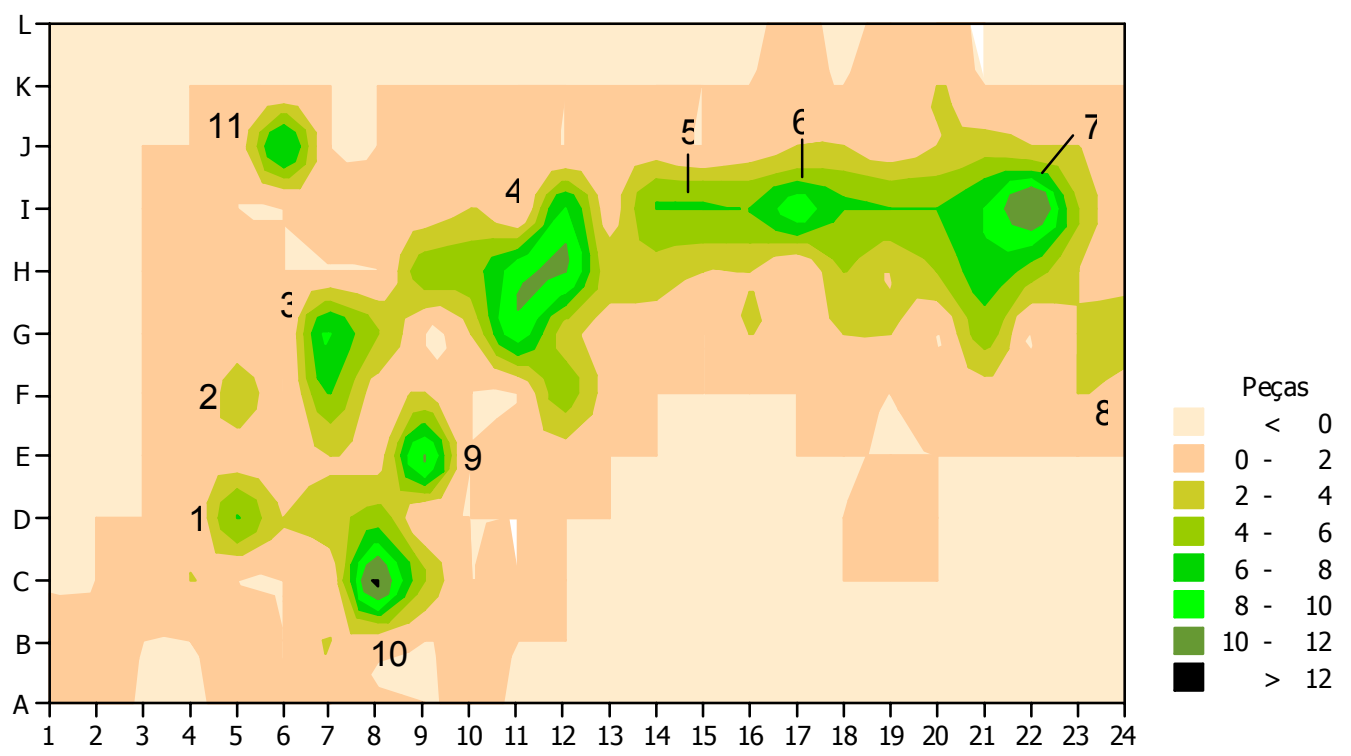

Figura 9 - Sítio Estiva 3

Densidade dos artefatos cerâmicos

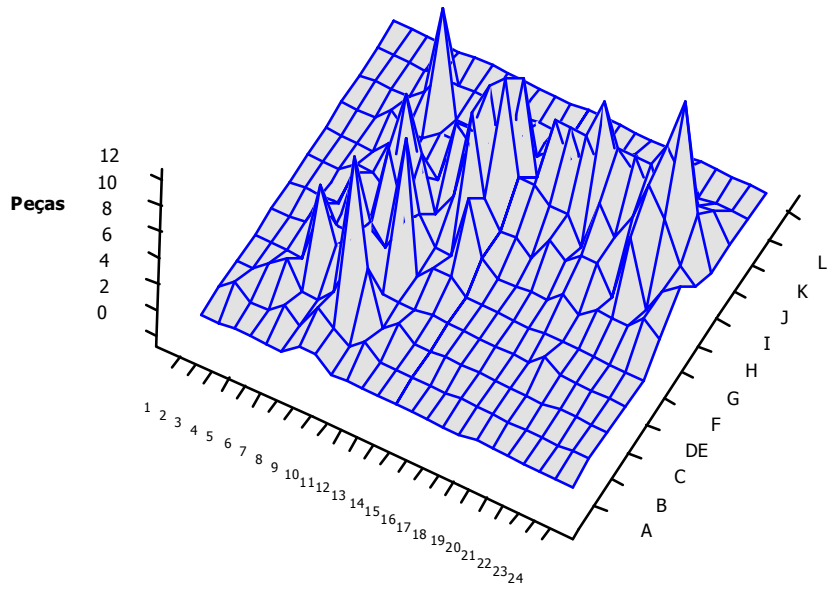


forma, a variabilidade neste sítio caracteriza-se principalmente através das variáveis de natureza tecnológica, pois são elas que comandam a organização dos agrupamentos. Assim sendo, os grupos 1 e 4 se diferenciam, por exemplo, pelos atributos antiplástico e espessura do antiplástico.

Analisados em conjunto, pode-se afirmar que no sítio Estiva 3 (filiado a tradição Uru) ocorre uma maior heterogeneidade nos artefatos cerâmicos do que no sítio Estiva 2 (filiado a tradição Aratu). Semelhante ao que foi detectado por Wüst em sítios localizados no estado do Mato Grosso (1990, 2000), em Estiva 3 não apenas o grau de variabilidade, mas, sobretudo a natureza da mesma informa sobre diferenças básicas de ambas estas sociedades. Desta forma, aparentemente poderia ter existido um envolvimento diferenciado entre as unidades residenciais do assentamento no tocante à manufatura dos artefatos cerâmicos (variáveis tecnológicas e estilísticas comandam a variabilidade). Esta seria uma atividade restrita a algumas unidades, o que poderia explicar a presença das bolotas de argila, tidas como sobras do processo de manufatura cerâmica, concentradas entre as áreas de concentração 8 e 9 (figura 8), bem como as peças com decoração, principalmente marcas de cestaria, localizadas entre as concentrações 5,6 e 2 .

Podemos supor, então, que as concentrações 8 e 9 poderiam estar relacionadas a manufatura de uma diversidade de artefatos e que após o abandono do sítio este seria um bom local para reaproveitamento de matéria-prima. E de fato, a maior concentração tanto de material relacionado à tradição Aratu, quanto material histórico contemporâneo foi localizada nesta área do sítio. O que interpretamos como um abandono por parte do grupo Aratu de material durante a exploração desta área, o mesmo podendo ter ocorrido com as populações caboclas que habitavam a área até sua desocupação por conta da formação do reservatório da UHE.

Quanto ao sítio Estiva 2, observa-se nele uma maior homogeneidade nas formas de vasilhames (sobretudo a presença maciça das formas 7 e 4, ambas com volumes superiores a 50 litros, por todo o sítio), no emprego do engobo vermelho, e nas variáveis tecnológicas como um todo. A distribuição espacial dispersa pelo assentamento tanto das peças com engobo quanto das formas de vasilhame 7 e 4 indica intensas redes de troca e/ou empréstimos internos.

Como apontado por Wüst em estudo com resultados similares em dois assentamentos também filiados às tradições Aratu e Uru, "uma distribuição nucleada ou generalizada dos chamados artefatos 'intrusivos' pode revelar a natureza dos fluxos de bens e de informação que envolvem sociedades culturalmente distintas" (Wüst 2000: 9). Assim sendo, também a distribuição dispersa em praticamente todas as concentrações do sítio de materiais "intrusivos" Uru indica a manutenção de uma rede interna de contatos em Estiva 2. 
Entretanto, não é tarefa simples identificar processos de interação e contato cultural entre sociedades distintas através da cultura material, uma vez que o abandono e/ou a manutenção de características estilísticas, por exemplo, encontram-se também intrinsecamente ligadas à própria natureza da interação, podendo ter havido tanto imposições de padrões estéticos quanto uma troca mútua, e apenas o registro material não é capaz de refletir tais processos complexos de contatos ou mesmo fusões culturais. 


\section{CONSIDERAÇõES FINAIS}

$\mathrm{B}_{\mathrm{ras}}$ rasil Central meados do século $X$ da nossa Era. Grupos ceramistas vindos de áreas a oeste da bacia do rio Araguaia iniciam um movimento migratório rumo leste, invadindo territórios outrora ocupados por sociedades ceramistas distintas, contudo que possuíam padrões culturais de organização do espaço ocupado muito semelhante aos dos invasores vindos do oeste. Deste encontro das sociedades construtoras de grandes aldeias circulares do Brasil Central emergiram complexos e intrincados processos de contatos e interações culturais, os quais a pesquisa arqueológica cada vez mais tenta vislumbrar através da realização, por exemplo, de projetos de vulto regional.

A bibliografia indica que, de fato, a interação entre os grupos ceramistas Aratu (ocupantes das áreas a leste do Araguaia) e os grupos Uru (os "intrusos" vindos do oeste) foi tão intensa a ponto de criar células de fusão entre os mesmos. Preconiza-se que desta fusão tenham resultados sítios que exibem elementos de ambos os grupos, porém com um gradativo predomínio das características dos grupos vindos do oeste. Tal configuração se deu muito em virtude dos aspectos internos que cada uma destas sociedades exibia, enquanto os grupos Uru passavam por um processo de franca expansão territorial, motivada talvez pelo aumento populacional ocorrido em sua área core, os grupos Aratu encontravamse em situação mais cômoda, e mesmo de retração interna. (Robrahn-González 1996a, 1996b; Wüst 1983, 1990 entre outros).

No médio rio Tocantins foram identificados diversos sítios arqueológicos representativos deste processo de fusão, nos quais recorrentemente haviam tanto artefatos relacionados a um grupo quanto ao outro, e mesmo de elementos outros, como os grupos Tupiguarani. Esta região pode ser caracterizada como um limite setentrional para este processo de expansão/interação iniciado mais a sul no alto curso dos rios Araguaia e Tocantins. Os sítios aí identificados, com datações tardias e indícios de interações não tão bem marcados quanto os identificadas, por exemplo, no alto rio Tocantins na região de 
Serra da Mesa, estado de Goiás (Pontim 2004, Souza 2003) possibilitaram a esta pesquisa supor que tal processo, apesar de intenso e abrangente, não foi fulminante e definitivo, de modo que em período tardio (séculos XIII - XV) ainda se processava com idas e vindas nestas terras mais setentrionais.

Aparentemente à onda migratória rumo leste e após certa acomodação, os grupos Uru teriam seguido rumo norte subindo a calha do rio Tocantins em busca de novos ambientes, lá também teriam encontrado assentamentos relacionados os grupos Aratu, talvez advindos de um momento anterior de migração, e iniciado nova onda de contatos, não apenas com estes, como também com os relacionados a tradição Tupiguarani que ali se localizavam.

As características dos sítios localizados no médio Tocantins nos permitem afirmar que eles já não possuíam, tanto morfologicamente quanto com relação a sua posição na paisagem, os padrões típicos dos antigos assentamentos, as aldeias são consideravelmente pequenas em comparação aos grandes sítios anelares ou circulares de suas áreas core, além de localizarem-se em diversos compartimentos da paisagem.

Os sítios aqui estudados enquadram-se neste novo perfil, são aldeias pequenas que exibem traços não bem demarcados de processos diversos de interação cultural. As análises efetuadas permitiram avaliar a variabilidade material em cada um destes assentamentos e desta forma levantar algumas hipóteses acerca de suas configurações sociais.

Para o sítio Estiva 2, relacionado aos grupos ceramistas Aratu, uma maior homogeneidade interna foi detectada em contrapartida de uma tendência a abertura frente a influências externas. A presença de materiais relacionados ao sítio Estiva 3 na área do assentamento talvez esteja relacionada a busca por parte de seus habitantes de novas técnicas de manufatura e/ou matérias-primas, disponíveis no terreno vizinho sem a necessidade de manutenção de redes de trocas externas, pois uma vez que Estiva 3 possui datação mais antiga, e também já foi preconizado para o Brasil Central, sendo ponto de concordância, que os assentamentos não permanecem mais de uma geração ocupados, ele já encontrava-se abandonado quando da chegada dos grupos Aratu. Fato que pode remeter a uma procura pelos mesmos ambientes por parte de ambos os grupos, questão esta que merece atenção em investigações futuras.

Por outro lado, no sítio Estiva 3 a variabilidade material apontou grande heterogeneidade interna e pouca permeabilidade a influências externas, sendo a única influência externa presente na cultura material a presença expedita do antiplástico caco moído, que remete a contatos de alguma natureza destes grupos Uru com sítios de grupos Tupiguarani, talvez o sítio Estiva 1, localizado a 1 km de distância deste. 
Assim sendo, é possível afirmar que tal qual identificado por Wüst em seus trabalhos no vale do São Lourenço no estado do Mato Grosso (1990) e na região do Mato Grosso de Goiás (1983), também no médio Tocantins os sítios das tradições Aratu e Uru apresentam como características marcantes a homogeneidade interna com aceitação de influências externas e a heterogeneidade interna com a pouca permeabilidade a influências externas respectivamente. Padrão mantido mesmo séculos depois do início da interação cultual entre estas populações.

De fato, talvez foram exatamente estas características que condicionaram, no Brasil Central, os contatos culturais entre estes grupos ceramistas desde pelo menos o século $\mathrm{X}$ da era Cristã, e como pode ser visto, tal processo continuou ainda que com especificidades, no médio Tocantins até meados do século XV. 


\section{REFERÊNCIAS BIBLIOGRÁFICAS}

DE ACORDO COM AS NORMAS DA ABNT

LIVROS, PERIÓDICOS E RELATÓRIOS

ALLISON, P. M. (Ed.) The archaeology of household activities. London: Routledge, 1999. 206 p.

ANDREATTA, M. D. Projeto Anhangüera de Arqueologia de Goiás (1975-1985). Revista do Museu Paulista (Nova Série), São Paulo: Universidade de São Paulo, vol. 33, p. 143-156, 1988.

Padrões de povoamento em pré-história goiana: análise de sítio tipo. 1982.

115 f. Tese (Doutorado) - Faculdade de Filosofia, Letras e Ciências Humanas, Universidade de São Paulo, São Paulo.

ARAUJO-COSTA, F. H. J. de C. de. Projeto baixo Tocantins: salvamento arqueológico na região de Tucuruí (Pará). 1983. 77 f. Dissertação (Mestrado) - Faculdade de Filosofia, Letras e Ciências Humanas, Universidade de São Paulo, São Paulo.

ARNOLD, P. J. The organization of refuse disposal and ceramic production within contemporany Mexican houselots. American Anthropologist, vol. 92, n. 4, p. 915-932, Dec. 1990.

BARBOSA, A. S.; SCHMITZ, P. I. \& MIRANDA, A. F. Projeto centro-sul de Goiás. Fase complementar - comunicação prévia. Anuário de Divulgação Científica, Goiânia: Universidade Católica de Goiás, n. 3-4, p. 45-59, 1976/77a.

Um sítio paleoíndio no médio norte de Goiás.

Anuário de Divulgação Científica, Goiânia: Universidade Católica de Goiás, n. 3-4, p. 2143, 1976/77b.

BARBOSA, A. S.; SCHMITZ, P. I.; STOBÄUS, A. \& MIRANDA, A. F. de. Projeto médio Tocantins: Monte do Carmo, GO. Fase cerâmica Pindorama. Pesquisas (Antropologia), São Leopoldo: Instituto Anchietano de Pesquisas, n. 34, p. 49-92, 1982.

BARNETT, W. K.; HOOPES, J. W. (Ed.). The emergence of pottery. Technology and innovation in ancient societies. Washington DC: Smithsonian Institution Press, 1995. 285 p. 
BERRA, J. C. de A. A arte rupestre na serra do Lajeado, Tocantins. 2003. $181 \mathrm{f}$, il., 1 CD. Dissertação (Mestrado) - Faculdade de Filosofia, Letras e Ciências Humanas, Universidade de São Paulo, São Paulo.

BROCHIER, L. L. Aspectos de interesse geoarqueológico na área do Programa de Resgate Arqueológico da UHE Lajeado/TO. [S.I.: s.n.], 2002. 8 p., il.

BUENO, L. M. R. Variabilidade tecnológica nos sítios líticos da região do Lajeado, médio rio Tocantins. 2005. Tese (Doutorado) - Faculdade de Filosofia, Letras e Ciências Humanas, Universidade de São Paulo, São Paulo.

CARR, C. The nature of organization of intrasite archaeological records and spatial analytic approaches to their investigation. In: SCHIFFER, M. B. (Ed.). Advances in archaeological method and theory, New York: Academic Press, vol. 7, p. 103-223, 1984.

CHMYZ, I. Terminologia arqueológica brasileira para a cerâmica. Cadernos de arqueologia, Paranaguá: Universidade Federal do Paraná, n. 1, p. 119-148, 1976.

CLARKE, D. L. (Ed.). Spatial archaeology. London: New York: Academic Press, 1977. 386 p.

COWGILL, G. L. Archaeological applications of factor, cluster, and proximity analysis. American Antiquity, vol. 33, n. 3, p. 367-375, Jul. 1968.

DE BLASIS, P. Diagnóstico do patrimônio arqueológico a ser impactado pela construção da UHE Lajeado, estado do Tocantins, e proposta de um programa de mitigação. Relatório Final. São Paulo: Museu de Arqueologia e Etnologia, Universidade de São Paulo, 1996b.

DE BLASIS, P. A. D.; ROBRAHN-GONZÁLEZ, E. M. Programa de resgate do patrimônio arqueológico da UHE Luis Eduardo Magalhães - Lajeado, estado do Tocantins. Relatório Final. São Paulo: Museu de Arqueologia e Etnologia, Universidade de São Paulo, 3 volumes, 2003.

Resgate do patrimônio arqueológico do eixo da UHE Lajeado e seu entorno, estado do Tocantins. Relatório Final. São Paulo: Museu de Arqueologia e Etnologia, Universidade de São Paulo, 1998.

FACCIO, N. B.; SOUZA, M. L.; VAZ, L. J. M. \& SANTOS, R. R. Subprograma materiais arqueológicos. In: MARTINS, D. C. (Coord.). Relatório conclusivo do PA-SALV-SM, vol. 6: Cerâmica. Goiânia: Museu Antropológico, Universidade Federal de Goiás, 1998. 
FERRI, M. G. Ecologia dos cerrados. In: FERRI, M. G. (Coord.). Simpósio sobre o cerrado (4., 1976, Brasília). São Paulo: Edusp; Belo Horizonte: Itatiaia, 1977. (Coleção Reconquista do Brasil, vol. 38). p. 15-33.

FOSTER, George M. Culture and conquest. America's Spanish Heritage. Chicago: Quadrangle Books, 1960.

HECKENBERGER, M. A periferia meridional amazônica: desenvolvimento cultural na fronteira entre a floresta tropical e o planalto central. In: Congresso DA SocIedAdE DE ARQUEOLOGIA BRASILEIRA, 9., 1997, Rio de Janeiro. Anais. Organização Sheila M. F. Mendonça de Souza. 1 CD. 2000.

INSTITUTO BRASILEIRO DE GEOGRAFIA E ESTATÍSTICA. Diretoria de Geociências. Geografia do Brasil, vol. 1: Região Centro-Oeste. Rio de Janeiro, 1988. 268 p.

HIETALA, H. (Ed.). Intrasite spatial analysis in archaeology. London: Cambridge University Press, 1984. 284 p.

HODDER, I.; ORTON, C. Spatial analysis in archaeology. Cambridge: Cambridge University Press, 1981. $270 \mathrm{p}$.

JOHNSON, R. A.; WICHERN, D. W. Applied multivariate statistical analysis. New Jersey: Practice Hall, 1982.

KENT, S. (Ed.). Understanding the use of space: an ethnoarchaeological approach. In: KENT, S. (Ed.). Method and theory for activity area research. An ethnoarchaeological approach. New York: Columbia University Press, 1987. p. 1-60.

LINTON, R. (Ed.). Acculturation in seven American Indian tribes. New York: D. Appleton-Century, 1940.

KROLL, E. M.; PRICE, T. D. (Ed.). The interpretation of archaeological spatial patterning. New York: London: Plenum Press, 1991. 315 p.

LEWARCH, D. E.; O'BRIEN, M. J. The expanding role of surface assemblages in archaeological research. In: SCHIFFER, M. B. (Ed.). Advances in archaeological method and theory, New York: Academic Press, vol. 4, p. 297-342, 1981. 
MARANCA, S. Estudo do sítio Aldeia da Queimada Nova, estado do Piauí. São Paulo: Museu Paulista, Universidade de São Paulo, 1976. 102 p. (Coleção Museu Paulista. Série de Arqueologia, n. 3).

MARTINS, D. C. Arqueologia da Serra da Mesa: planejamento, gestão e resultados de um projeto de salvamento arqueológico. 1999. 286 f. Tese (Doutorado) - Faculdade de Filosofia, Letras e Ciências Humanas, Universidade de São Paulo, São Paulo.

MARTINS, D. C. (Coord.). Relatório conclusivo do PA-SALV-SM. 13 volumes. Goiânia: Museu Antropológico, Universidade Federal de Goiás, 1998.

MAYBURY-LEWIS, D. (Ed.). Dialectical societies - the Gê and Bororo of Central Brazil. Cambridge: London: Harvard University Press, 1979. 340 p.

MEGGERS, B. J.; EVANS, C. Como interpretar a linguagem da cerâmica: manual para arqueólogos. Washington DC: Smithsonian Institution Press, 1970. 111 p.

MEGGERS, B. J.; MARANCA, S. Uma reconstituição experimental de organização social, baseada na distribuição de tipos de cerâmica num sítio habitação da tradição Tupiguarani. Pesquisas (Antropologia), São Leopoldo: Instituto Anchietano de Pesquisas, n. 31, p. 227-247, 1980.

MELLO, P. J. C. Análise do material cerâmico do sítio Quebra-Pau 2 (GO-NI-83). Cadernos de Pesquisa, Goiânia: Instituto Goiano de Pré-História e Antropologia, Universidade Católica de Goiás, n. 9, p. 51-63, 1995.

MIGLIÁCIO, M. C. A ocupação pré-colonial do pantanal de Cáceres - Mato Grosso: uma leitura preliminar. 2000. 2 v., anexos. Dissertação (Mestrado) - Faculdade de Filosofia, Letras e Ciências Humanas, Universidade de São Paulo, São Paulo.

MIRANDA, A. F. de. Notas sobre o habitat dos horticultores do centro-sul de Goiás. Pesquisas (Antropologia), São Leopoldo: Instituto Anchietano de Pesquisas, n. 31, p. 165-183, 1980.

MOI, F. P. Organização e uso do espaço em duas aldeias Xerente: uma abordagem etnoarqueológica. 2003. 203 f, anexos. Dissertação (Mestrado) - Faculdade de Filosofia, Letras e Ciências Humanas, Universidade de São Paulo, São Paulo.

MORALES, W. F. 12.000 anos de ocupação: um estudo de arqueologia regional na bacia do córrego Água Fria, médio curso do rio Tocantins. 2005. Tese (Doutorado) - Faculdade de Filosofia, Letras e Ciências Humanas, Universidade de São Paulo, São Paulo. 
NIMUENDAJÚ, C. The Serente. Los Angeles: The Southwest Museum, 1942. 106 p. (Publications of the Frederick Webb Hodge Anniversary Publication Fund., vol. IV).

OLIVEIRA, E. R. de. Os grupos ceramistas do médio curso do rio Tocantins: uma abordagem espacial intra-sítio em dois estudos de caso. 2004. Memorial de Qualificação (Mestrado) Museu de Arqueologia e Etnologia, Universidade de São Paulo, São Paulo.

OLIVEIRA, J. E. de. Os argonautas Guató: aportes para o conhecimento dos assentamentos e da subsistência dos grupos que se estabeleceram nas áreas inundáveis do Pantanal Matogrossense. 1995. 210 f, il. Dissertação (Mestrado) - Instituto de Filosofia e Ciências Humanas, Pontifícia Universidade Católica do Rio Grande do Sul, Porto Alegre.

OLIVEIRA, J. E. de; VIANA, S. A. O Centro-Oeste antes de Cabral. Revista da USP - Dossiê Antes de Cabral: Arqueologia Brasileira, São Paulo, n. 44, vol. 1, p. 142-189, 1999/00.

ORTON, C.; TYERS, P.; VINCE, A. Pottery in Archaeology. Cambridge: Cambridge University Press, 1997. 269 p. (Cambridge Manuals in Archaeology).

PEIXOTO, J. L. dos S. A ocupação dos povos indígenas pré-coloniais nos grandes lagos do Pantanal sul-matogrossense. 2003. Tese (Doutorado) - Instituto de Filosofia e Ciências Humanas, Pontifícia Universidade Católica do Rio Grande do Sul, Porto Alegre.

A ocupação Tupiguarani na borda oeste do Pantanal sul-matogrossense: maciço do Urucum. 1995. Dissertação (Mestrado) - Instituto de Filosofia e Ciências Humanas, Pontifícia Universidade Católica do Rio Grande do Sul, Porto Alegre.

PLOG, S.; PLOG, F. \& WAIT, W. Decision making in modern surveys. In: SCHIFFER, M. B. (Ed.). Advances in archaeological method and theory, New York: Academic Press, vol. 1, p. 383-421, 1978.

PONTIM, R. de L. Configuração do povoamento pré-colonial do norte goiano: o caso dos grupos ceramistas. 2004. 152 f, il. Dissertação (Mestrado) - Faculdade de Filosofia, Letras e Ciências Humanas, Universidade de São Paulo, São Paulo.

REDMAN, C. L. Surface collection, sampling, and research design: a retrospective. American Antiquity, vol. 52, n. 2, p. 249-265, Apr. 1987.

Multistage fieldwork and analytical techniques. American Antiquity, vol. 38, n. 1, p. 61-79, Jan. 1973.

REDMAN, C. L.; WATSON, P. J. Systematic, intensive surface collection. American Antiquity, vol. 35, n. 3, p. 279-291, Jul. 1970. 
RICE, P. M. Pottery analysis: a sourcebook. Chicago: University of Chicago Press, 1987. 559 p.

Pots and potters: current approaches in ceramic archaeology. Los Angeles: Institute of Archaeology, University of California, 1984. 255 p.

ROBRAHN-GONZÁLEZ, E. M. A aplicação do modelo etnoarqueológico Xerente de uso do espaço em sítios cerâmicos do Brasil Central: estudos de analogia. In: CONGRESSO DA SOCIEDADE DE ARqueOlogia Brasileira, 12., 2003, São Paulo. Resumos, 2003.

Repensando as fronteiras culturais de grupos ceramistas no estado de São Paulo. In: Congresso dA SociedAde De ARQUeologia BrasileIRA, 12., 2003, São Paulo. Resumos, 2003. p. 175.

São Paulo, terra de fronteiras: a ocupação de grupos ceramistas précoloniais. In: Congresso da SociedAde de Arqueologia BrasileiRA, 9., 1997, Rio de Janeiro. Anais. Organização Sheila M. F. Mendonça de Souza. 1 CD. 2000.

Teoria e métodos na análise cerâmica em arqueologia. Revista do Museu de Arqueologia e Etnologia, São Paulo: Universidade de São Paulo, n. 8, p. 287294, 1998b.

Os grupos ceramistas pré-coloniais do Brasil Central: origens e desenvolvimento. 1996a. 232 f. Tese (Doutorado) - Faculdade de Filosofia, Letras e Ciências Humanas, Universidade de São Paulo, São Paulo.

Os grupos ceramistas pré-coloniais do Centro-Oeste brasileiro. Revista do Museu de Arqueologia e Etnologia, São Paulo: Universidade de São Paulo, n. 6, p. 83-121, 1996b.

ROBRAHN-GONZÁLEZ, E. M.; DE BLASIS, P. A. D. Pesquisas arqueológicas no médio vale do rio Tocantins: o resgate no eixo da UHE Luis Eduardo Magalhães. Revista de Arqueologia, Rio de Janeiro: Sociedade de Arqueologia Brasileira, vol. 10, p. 7-50, 1997.

ROGGE, J. H. Fenômenos de fronteira: um estudo das situações de contato entre os portadores das tradições cerâmicas pré-históricas no Rio Grande do Sul. 2004. 241 f. Tese (Doutorado) - Centro de Ciências Humanas, UNISINOS, São Leopoldo.

RYE, O. S. Pottery technology. Principles and reconstruction. Washington DC: Smithsonian Institution Press, 1981. 150 p. (Manuals on Archaeology 4).

SCHMITZ, P. I. Arqueologia nos cerrados do Brasil Central: sudoeste da Bahia e leste de Goiás. O projeto Serra Geral. Pesquisas (Antropologia), São Leopoldo: Instituto Anchietano de Pesquisa, n. 52, 1996.

A evolução da cultura no sudoeste de Goiás, Brasil. Pesquisas (Antropologia), São Leopoldo: Instituto Anchietano de Pesquisas, n. 31, p. 185-225, 1980. 
Arqueologia de Goiás: seqüência cultural e datações C14. Anuário de Divulgação Científica, Goiânia: Universidade Católica de Goiás, n. 3-4, p. 1-17, 1976/77.

SCHMITZ, P. I.; BARBOSA, A. S. Horticultores pré-históricos do estado de Goiás. São Leopoldo: Instituto Anchietano de Pesquisas, 1985. 45 p.

SCHMITZ, P. I.; MOEHLECKE, S. \& BARBOSA, A. S. Sítios de petroglifos nos projetos alto-Tocantins e alto-Araguaia, Goiás. Pesquisas (Antropologia), São Leopoldo: Instituto Anchietano de Pesquisas, n. 30, 1979.

SCHMITZ, P. I.; WÜST, I.; BARBOSA, A. S. \& BECKER, I. I. B. Projeto alto Tocantins, Goiás (comunicação prévia). Anuário de Divulgação Científica, Goiânia: Universidade Católica de Goiás, n. 1-2, p. 1-21, 1974/75.

SCHMITZ, P. I.; WÜST, I. \& COPÉ, S. M. Os horticultores do centro-sul de Goiás. Arquivo do Museu de História Natural, Belo Horizonte, vol. 6-7, p. 221-234, 1981/82.

SCHMITZ, P. I.; WÜST, I.; COPÉ, S. M. \& THIES, U. M. E. Arqueologia do centro-sul de Goiás. Uma fronteira de horticultores indígenas no centro do Brasil. Pesquisas (Antropologia), São Leopoldo: Instituto Anchietano de Pesquisas, n. 33, 1982.

SCHMITZ, P. I.; RIBEIRO, M. B.; BARBOSA, A. S.; BARBOSA, M. O. \& MIRANDA, A. F. Caiapônia. Arqueologia nos cerrados do Brasil Central. São Leopoldo: Instituto Anchietano de Pesquisas, 1986. 334 p. (Publicações avulsas, n. 8)

SEEGER, A. Nature and society in Central Brazil: the Suya Indians of Mato Grosso. Cambridge: Harvard University Press, 1981. 278 p.

SHEPARD, A. O. Ceramics for the archaeologist. Washington DC: Carnegie Institute of Washington, 1985. 414 p. (Publication 609).

SIMÕES, M. F.; ARAUJO-COSTA, F. Pesquisas arqueológicas no baixo rio Tocantins (Pará). Revista de Arqueologia, Belém, vol. 4, n. 1, p. 11-27, jun. 1987.

SILVA, F. A. As tecnologias e seus significados: um estudo da cerâmica dos Asuriní do Xingu e da cestaria dos Kayapó-Xikrin sob uma perspectiva etnoarqueológica. 2000. 244 f, il., 1 anexo. Tese (Doutorado) - Faculdade de Filosofia, Letras e Ciências Humanas, Universidade de São Paulo, São Paulo. 
SIMONSEN, I.; SOUZA, A. A. C. M. de; OLIVEIRA, A. de P.; SOUZA, S. M. F. de \& SOUZA, M. A. C. M. de. Sítios cerâmicos da bacia do Paranã, Goiás. Arquivo do Museu de História Natural, Belo Horizonte, vol. 8-9, p. 121-129, $1983 / 84$.

SOUZA, M. de L. Estudos de sítios arqueológicos na bacia do rio Tocantins: análise arqueológica. 2003. 286 f. Tese (Doutorado) - Faculdade de Filosofia, Letras e Ciências Humanas, Universidade de São Paulo, São Paulo.

SPICER, E. (Ed). Perspectives in American Indian culture change. Chicago: University of Chicago Press, 1961.

TURNER, T. S. Kinship, household, and community structure among the Kayapó. In: MAYBURYLEWIS, D. (Ed.). Dialectical societies - the Gê and Bororo of Central Brazil. Cambridge: London: Harvard University Press, 1979a. p. 179-217.

The Gê and Bororo societies as dialectical systems: a general model. In: MAYBURYLEWIS, D. (Ed.). Dialectical societies - the Gê and Bororo of Central Brazil. Cambridge: London: Harvard University Press, 1979b. p. 147-178.

VERONEZE, E. A ocupação do planalto central brasileiro: o nordeste do Mato Grosso do Sul. 1993. 231 f. Dissertação (Mestrado) - UNISINOS, Instituto Anchietano de Pesquisas, São Leopoldo.

VIANA, S. A. Análise espacial intra-sítio: o estudo do sítio Lourenço (GO-CA-14). Revista de Arqueologia, Rio de Janeiro: Sociedade de Arqueologia Brasileira, vol. 9, p. 65-88, 1996.

WARMING, E.; FERRI, M. G. Lagoa Santa e a vegetação dos cerrados brasileiros. Belo Horizonte: Itatiaia; São Paulo: Edusp, 1973.

WHALLON, R. Jr. Spatial analysis of occupation floors II: the application of nearest neighbor analysis. American Antiquity, vol. 39, n. 1, p. 16-34, Jan. 1974.

Spatial analysis of occupation floors I: application of dimensional analysis of variance. American Antiquity, vol. 38, n. 3, p. 266-278, Jul. 1973.

WILMSEN, E. N. (Ed.). Social exchange and interaction. Anthropological papers. Ann Arbor: University of Michigan, 1972. (Museum of anthropology, University of Michigan, n. 46).

WÜST, I. As implicações teóricas e práticas da análise espacial intra-sítio no estudo das sociedades ceramistas pré-coloniais do centro-oeste brasileiro. In: CONGRESSO DA SOCIEDADE DE ARqueOlogia Brasileira, 9., 1997, Rio de Janeiro. Anais. Organização Sheila M. F. Mendonça de Souza. 1 CD. 2000. 
As aldeias dos agricultores ceramistas do Centro-Oeste brasileiro. In: TENÓRIO, M. C. (Org.). Pré-História da Terra Brasilis. Rio de Janeiro: Universidade Federal do Rio de Janeiro, 1999. p. 321-337.

Continuities and discontinuities: archaeology and ethnoarchaeology in the heart of the Eastern Bororo territory, Mato Grosso, Brazil. Antiquity, vol. 72, n. 277, p. 663-675, Sept. 1998.

Continuidade e mudança: para uma interpretação dos grupos ceramistas pré-coloniais da bacia do rio Vermelho, Mato Grosso. 1990. 3 v. Tese (Doutorado) - Faculdade de Filosofia, Letras e Ciências Humanas, Universidade de São Paulo, São Paulo: Goiânia.

Aspectos da ocupação pré-colonial em uma área do Mato Grosso de Goiás: tentativa de análise espacial. 1983. 357 f, 21 anexos. Dissertação (Mestrado) - Faculdade de Filosofia, Letras e Ciências Humanas, Universidade de São Paulo, São Paulo.

Primeiros resultados e perspectivas de uma análise espacial em uma área do Mato Grosso de Goiás. Arquivo do Museu de História Natural, Belo Horizonte, vol. 6-7, p. 235-247, $1981 / 82$

Observações sobre a tecnologia cerâmica Karajá de Aruanã. Arquivo do Museu de História Natural, Belo Horizonte, vol. 6-7, p. 311-327, 1981/82.

A cerâmica Carajá de Aruanã. Anuário de Divulgação Científica, Goiânia: Universidade Católica de Goiás, n. 2, p. 91-165, 1975.

WÜST, I.; BARRETO, C. N. The ring villages of Central Brazil: a challenge for Amazonian archaeology. Latin American Antiquity, vol. 10, n. 1, p. 3-23, Mar. 1999.

WÜST, I.; CARVALHO, H. B. Novas perspectivas para o estudo dos ceramistas pré-coloniais do Centro-Oeste brasileiro: a análise espacial do sítio Guará 1 (GO-NI-100), Goiás. Revista do Museu de Arqueologia e Etnologia, São Paulo: Universidade de São Paulo, n. 6, p. 47-81, 1996.

\section{MAPA}

INSTITUTO BRASILEIRO DE GEOGRAFIA E ESTATÍSTICA. Diretoria de Geociências. Folha Tocantins SC-22. 3. ed., Rio de Janeiro, 1998. 1 mapa, color. Escala 1: 1.000.000.

Mídia ELETRÔNICA (CDROM)

EMPRESA BRASILEIRA DE PESQUISA AGROPECUÁRIA. Coleção Brasil visto do espaço: estado do Tocantins. Embrapa monitoramento por satélite, 2002. 1 CD-ROM. 
INSTITUTO BRASILEIRO DE GEOGRAFIA E ESTATÍSTICA. Folha Tocantins SC-22: geologia, geomorfologia, vegetação, uso potencial da terra [1981]. Edição fac-similar. Rio de Janeiro: Projeto RADAMBRASIL, 2003. (Levantamento de recursos naturais, v. 22). 1 CD-ROM.

MíDIA ELETRÔNICA (INTERNET)

INSTITUTO BRASILEIRO DE GEOGRAFIA E ESTATÍSTICA. Mapa do Brasil - bacias hidrográficas. Disponível em: <http://www.ibge.gov.br>. Acesso em: 19 jan. 2005.

INSTITUTO BRASILEIRO DE GEOGRAFIA E ESTATÍSTICA. Mapa série Brasil cartográfico (imagem ESRI Map Kit). 2. ed., 2002. Escala 1:5.000.000. Disponível em: <http:// www.mapas.ibge.gov.br/website/index mapas.html>. Acesso em: 05 jan. 2005.

SECRETARIA DO PLANEJAMENTO E MEIO AMBIENTE (Tocantins). Diretoria de Pesquisa e Informação. Anuário estatístico do estado do Tocantins 1997-2003. Palmas, 2004. Disponível em: <http://www.seplan.to.gov.br/desenvolvimento/dpi/index3.php>. Acesso em: 23 dez. 2004.

SECRETARIA DO PLANEJAMENTO E MEIO AMBIENTE (Tocantins). Mapa de potencial hidrelétrico. Disponível em: <http://www.ceuto.seplan.to.gov.br>. Acesso em: 19 jan. 2005. 


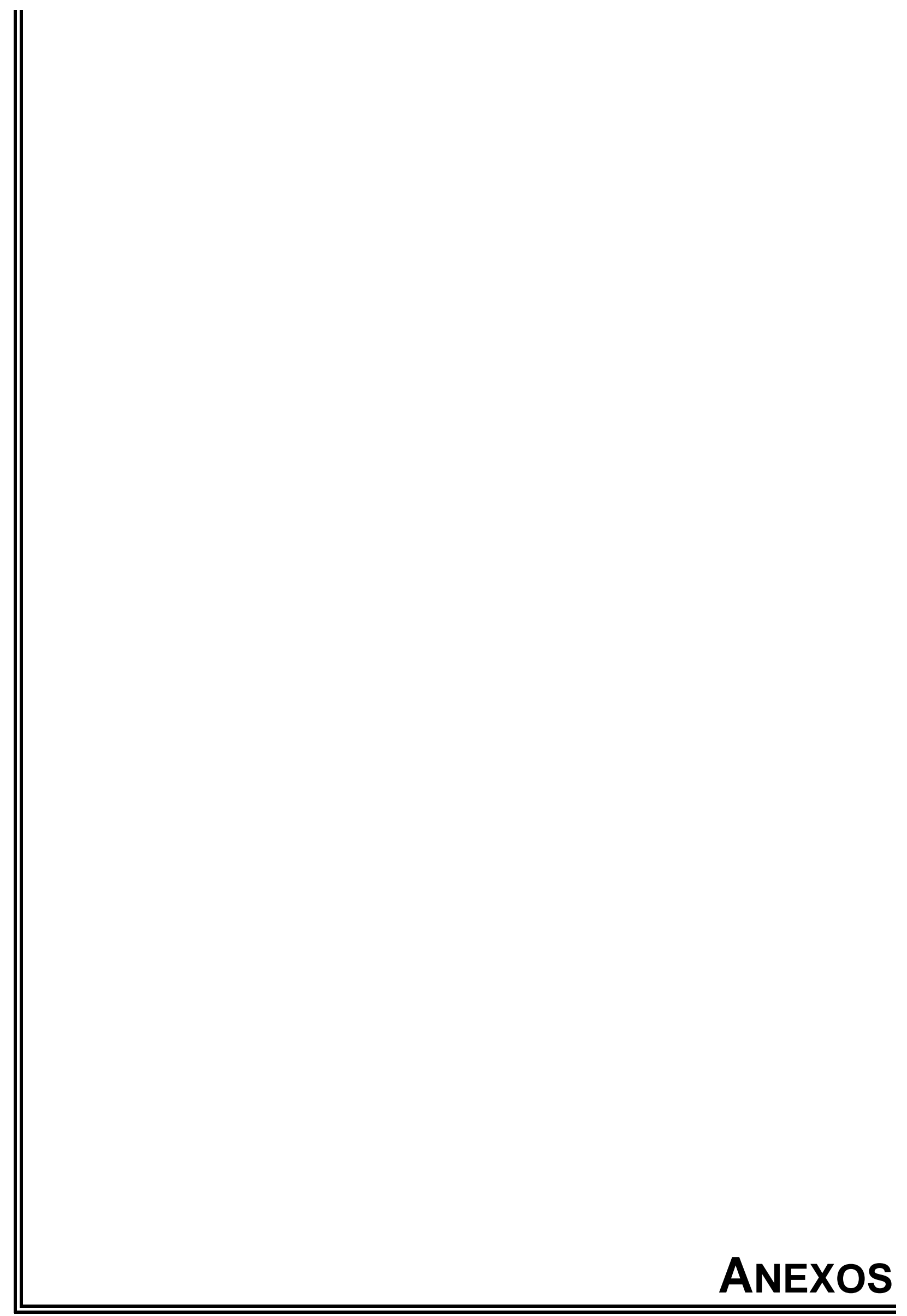




\section{ANEXO 1}

SÍTIO ESTIVA 2 - ANÁLISE ESTATÍSTICA

Sítio Estiva 2 - Dendograma da análise de cluster

Distance

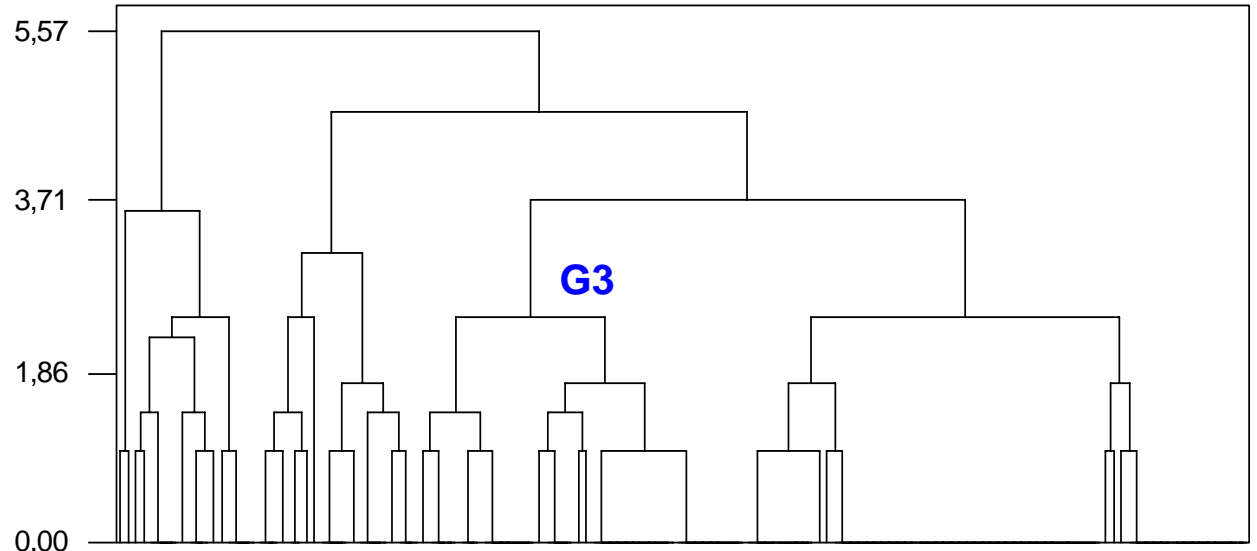

G2 G4

Observations

G1

Sítio Estiva 2 - Gráfico da análise de Componente Principal

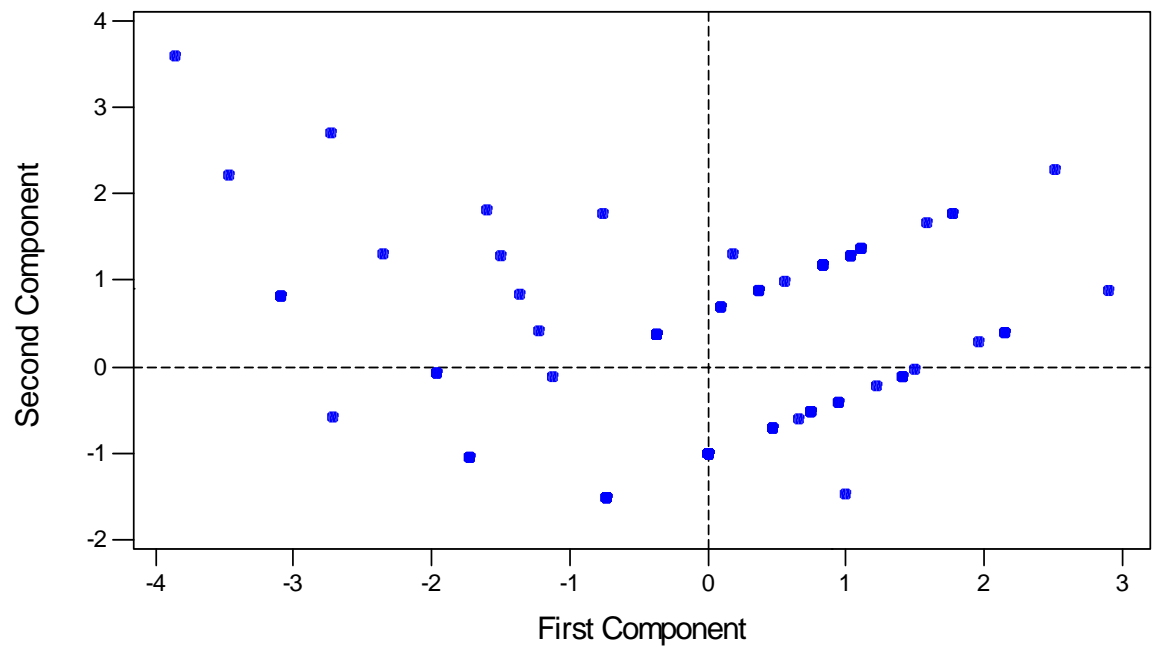




\section{ANEXO 2}

SÍTIO ESTIVA 3 - ANÁLISE ESTATÍSTICA

Sítio Estiva 3 - Dendograma da análise de Cluster

Distance

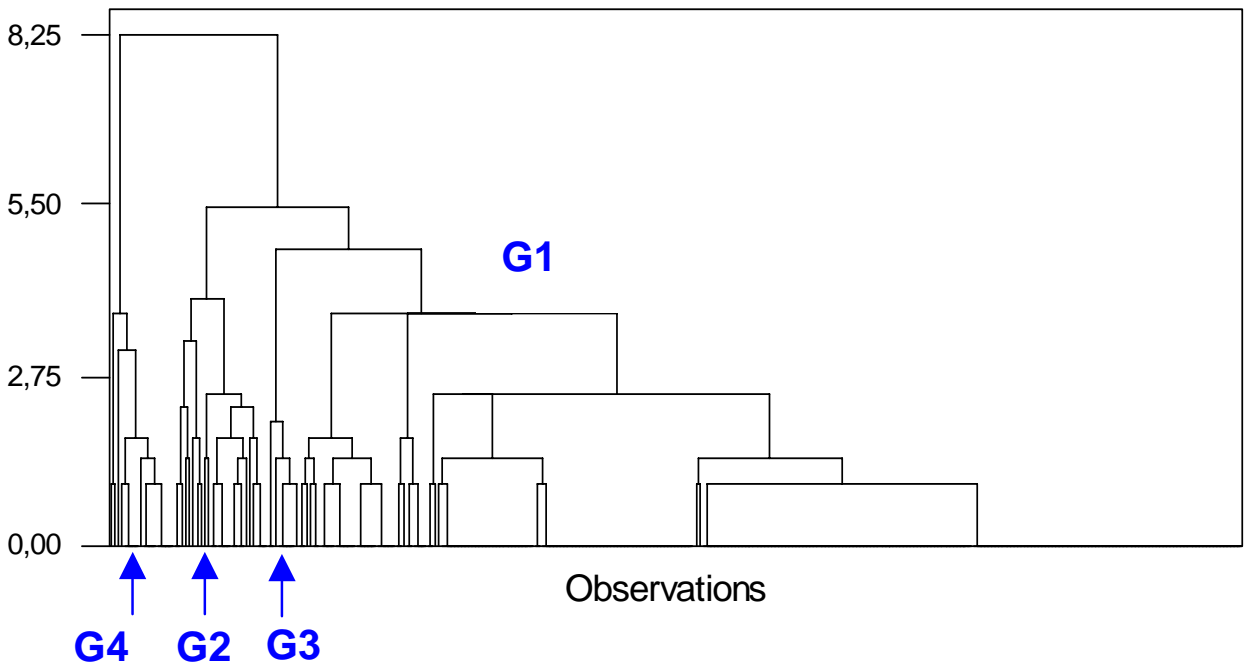

Sítio Estiva 3 - Gráfico da análise de Componente Principal

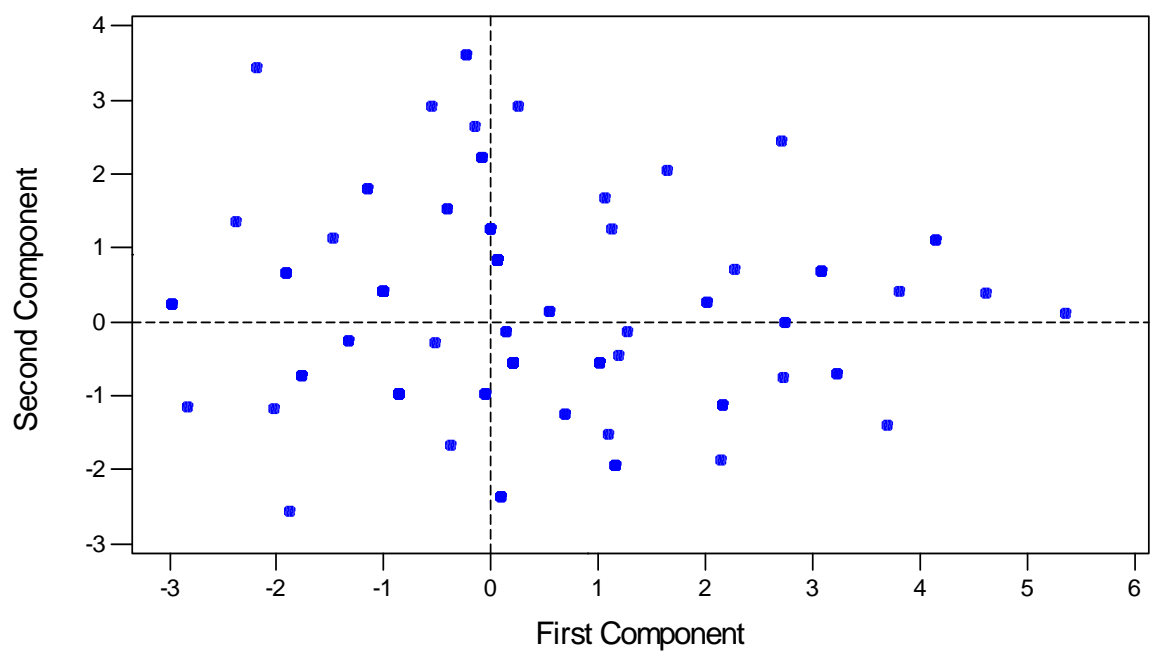

